JULIANA LAINO DO VAL CARNEIRO

\title{
Avaliação do papel dos miRNAs -221, -222 e -4728-3p em células-tronco tumorais derivadas de linhagens celulares de câncer de mama HER2+
}

Tese apresentada ao Programa de Pós-Graduação Interunidades em Biotecnologia USP/Instituto Butantan/IPT da Universidade de São Paulo, para obtenção do Título de Doutor em Biotecnologia. 


\section{Avaliação do papel dos miRNAs -221, -222 e -4728-3p em células-tronco tumorais derivadas de linhagens celulares de câncer de mama HER2+}

Tese apresentada ao Programa de Pós-Graduação Interunidades em Biotecnologia USP/Instituto Butantan/IPT da Universidade de São Paulo, para obtenção do Título de Doutor em Biotecnologia.

Área de concentração: Biotecnologia

Orientador: Dr. Emmanuel Dias-Neto

Co-orientadora: Dra. Diana Noronha Nunes

Versão original 
DADOS DE CATALOGAÇÃO NA PUBLICAÇÃO (CIP)

Serviço de Biblioteca e Informação Biomédica do

Instituto de Ciências Biomédicas da Universidade de São Paulo

reprodução não autorizada pelo autor

Carneiro, Juliana Laino do Val.

Avaliação do papel dos miRNAs -221, -222 e -4728-3p em célulastronco tumorais derivadas de linhagens celulares de câncer de mama HER2+ / Juliana Laino do Val Carneiro. -- São Paulo, 2013.

Orientador: Prof. Dr. Emmanuel Dias-Neto.

Tese (Doutorado) - Universidade de São Paulo. Instituto de Ciências Biomédicas. Programa de Pós-Graduação Interunidades em Biotecnologia USP/IPT/Instituto Butantan. Área de concentração:

Biotecnologia. Linha de pesquisa: Células-tronco tumorais de mama.

Versão do título para o inglês: Evaluation of the role of miRNAs 221, -222 e -4728-3p in breast cancer stem cells derived from HER2+ cell lines.

1. Células-tronco tumoral 2 2. Câncer de mama 3. miRNA-221 4. miRNA-222 5. miRNA-4728-3p I. Dias-Neto, Prof. Dr. Emmanuel II. Universidade de São Paulo. Instituto de Ciências Biomédicas. Programa de Pós-Graduação Interunidades em Biotecnologia USP/IPT/Instituto Butantan III. Título. 


\section{UNIVERSIDADE DE SÃO PAULO \\ Programa de Pós-Graduação Interunidades em Biotecnologia}

Universidade de São Paulo, Instituto Butantan, Instituto de Pesquisas Tecnológicas

Candidato(a): $\quad$ Juliana Laino do Val Carneiro.

Título da Tese: $\quad$ Avaliação do papel dos miRNAs -221, -222 e -4728-3p em células-tronco tumorais derivadas de linhagens celulares de câncer de mama HER2+ .

Orientador(a):

Prof. Dr. Emmanuel Dias-Neto.

A Comissão Julgadora dos trabalhos de Defesa da Tese de Doutorado, em sessão pública realizada a .................., considerou
( ) Aprovado(a)
( ) Reprovado(a)

Examinador(a): Assinatura:

Nome:

Instituição:

Examinador(a): Assinatura:

Nome:

Instituição:

Examinador(a): Assinatura:

Nome:

Instituição:

Examinador(a): Assinatura:

Nome:

Instituição:

Presidente: Assinatura:

Nome:

Instituição: 
Aos meus querídos país, Aurélio e Maria Thereza, que sempre estiveram presentes nos momentos maís dificeis do meu doutorado, pela dedicação, incentivo e apoio constante. Obrigada!

Ȧ minha querida vovó Gina. $\mathcal{E}$ aos meus querídos avós, Roberto e Ivone (in memoriam). Saudades! 


\section{AGRADECIMENTOS}

Ao Dr. Emmanuel Dias-Neto e à Dra. Diana Noronha Nunes, que sempre foram muito prestativos e eficientes diante dos contratempos permeados nesse período, pela orientação, apoio e comprometimento.

Ao programa de bolsas europeu Erasmus Mundus External Window, pela maravilhosa oportunidade de realização do doutorado sanduíche na Università Degli Studi di Napoli Federico II, na Itália.

À Dra Gerolama Condorelli e ao seu grupo, especialmente à Giuseppina Roscigno, Margherita Iaboni e Cristina Quintavalle, por me receberem muito bem em seu laboratório e pelos ensinamentos metodológicos aprendidos durante o doutorado sanduíche.

Aos colegas do Laboratório de Genômica Médica do AC Camargo Cancer Center, Maria G. Amorim, Gabriela P. Branco, Andrew M. Thomas, Frederico O. G. Netto, Gustavo R. Fernandes e Sheila pelo companheirismo.

À Andrea Glatt e ao Fernando Pretel ambos do CEFAP (Centro de Facilidades para Pesquisa) do ICB-USP, pelo conhecimento técnico nas análises de citometria de fluxo.

À Dra Desirè Bonci e ao seu grupo da Università degli Studi di Roma "La Sapienza", pela colaboração neste trabalho.

À Coordenação de Aperfeiçoamento de Pessoal de Nível Superior (CAPES) e a Pró-Reitoria de Pós-Graduação da Universidade de São Paulo, pela concessão da bolsa de doutorado.

À Fundação de Amparo à Pesquisa do Estado de São Paulo (FAPESP), pelo suporte financeiro indispensável para o desenvolvimento deste projeto. 
Ao Centro Internacional de Pesquisa e Ensino (CIPE) do AC Camargo Cancer Center, por toda a infra-estrutura física que permitiu a realização desse trabalho.

À Universidade de São Paulo, pelo suporte acadêmico que contribuiram para a minha formação.

À Associazione Italiana per la Ricerca sul Cancro (AIRC) pelo apoio finaceiro neste trabalho durante o doutorado na Itália.

Aos meus queridos irmãos, Marco Aurélio e Patrícia pelo amor, carinho e apoio.

Às grandes amizades realizadas na Itália, Fábio de Oliveira Martins, Florência Gonzalez Leone, Paula Mussnich, Aga Wlazly e Giuseppina Roscigno, pelos maravilhosos e inesquecíveis momentos juntos durante este período.

Aos antigos e novos amigos e colegas do CIPE, Tonielli Lacerda, Fernanda Carvalho, Hellen Kuasne, Iara S. Rodrigues, Roberto Ferreira, Fábio Marchi, Aderbal Ruy, Juliano Jampietro, Bianca Teixeira, Danilo, Felipe Moreira, Bruna Roz, Marcos Salles, pelo incentivo, apoio e pelos momentos de descontração. 
"Averdadeira viagem de descobrimento não consiste em procurar novas paisagens, esim em ter novos alhos".

Marcel Proust 


\section{RESUMO}

CARNEIRO, J. L. V. Avaliação do papel dos miRNAs -221, -222 e -4728-3p em célulastronco tumorais derivadas de linhagens celulares de câncer de mama HER2+. 2013. 122 p. Tese (Doutorado em Biotecnologia) - Instituto de Ciências Biomédicas, Universidade de São Paulo, São Paulo, 2013.

Estudos têm demonstrado que uma pequena população de células em tumores de mama, denominadas células iniciadoras de tumores ou células-tronco tumorais (CSCs - do inglês Cancer Stem Cells), são altamente tumorigênicas quando injetadas em camundongos imunodeficientes. As CSCs, caracterizadas pela expressão de CD44 concomitante à expressão baixa ou indetectável de $\mathrm{CD} 24\left(\mathrm{CD} 44^{+} \mathrm{CD} 24^{- \text {baixa }}\right)$ e a alta atividade da enzima aldeído desidrogenase (ALDH1), contribuem para a agressividade tumoral, desenvolvimento de metástases e a resistência à radio- e à quimioterapia. OCT-4, NANOG, SOX2, KLF4, LIN28 são alguns dos marcadores de pluripotência de células-tronco embrionárias que poderiam estar presentes nas CSCs. Tumores de mama HER2+, quando comparados a tumores sem a amplificação deste oncogene, são ricos em CSCs, o que parece ser uma das bases de sua maior agressividade. Estudos anteriores mostraram a expressão aumentada dos miRNAs -221 e -222 em CSCs de mama, assim como a elevação dos níveis de miRNA-4728-3p (mapeado em um intron de HER2) em tumores e linhagens tumorais HER2+. Neste trabalho buscou-se contribuir para um melhor entendimento do papel dos miRNAs -221, -222 e -4728-3p na biologia das CSCs em linhagens celulares de mama. Para isto, inicialmente foram feitos experimentos com células de pacientes e células MCF-7 cultivadas em condições aderentes e de mamosferas (estruturas celulares esferóides ricas em CSCs). Foi observado que, em relação às células crescidas em condições aderentes, as mamosferas possuiam níveis aumentados de CD44, OCT-4, NANOG e $S O X 2$, uma menor expressão de CD24 e uma elevação da expressão dos miRNAs -221 e -222,. A eficiência de formação de esferas (MFE) de células MCF-7 mostrou-se aumentada após a indução da superexpressão dos miRNAs -221 e -222. A resistência ao quimioterápico paclitaxel estava aumentada em mamosferas que superexpressavam o miRNA-222. Em conjunto esses dados sugerem um possível papel desses miRNAs na biologia das CSCs derivadas da linhagem MCF-7. Posteriormente, OCT-4, NANOG, SOX2, KLF4, LIN28, bem como os miRNAs -221, -222, -4728-3p foram avaliados por qRT-PCR em mamosferas derivadas das linhagens HER2+, BT-474 e SKBR3, e MCF-7. CD44, CD24 e ALDH1 foram analisados em mamosferas derivadas dessas mesmas linhagens por citometria de fluxo. O fenótipo $\mathrm{CD} 44^{+} \mathrm{CD} 24^{- \text {baixa }}$ não se mostrou aumentado em mamosferas derivadas dessas linhagens, algo que pode ser explicado pela associacão desse fenótipo com CSCs derivadas de células com perfil basal/mesenquimal. Apesar dos miRNAs e dos supostos marcadores $O C T-4, N A N O G, S O X 2, K L F 4, L I N 28$ não estarem aumentados em todos os tempos de cultivo, mamosferas com 7 dias de cultivo apresentaram altos níveis de ALDH1, que é considerada o marcador "padrão ouro" para o isolamento de subpopulações de CSCs em linhagens celulares HER2+. Esse resultado sugere um enriquecimento de CSCs em mamosferas das linhagens HER2+, BT-474 e SKBR3, e MCF-7. A superexpressão de miR-4728-3p, localizado em um intron de HER2, levou a um aumento das subpopulações ALDH1+ em duas linhagens celulares reforçando seu envolvimento com a biologia de CSCs.

Palavras-chave: Células-tronco tumorais. Câncer de mama. miR-221. miR-222. miR-4728-3p. 


\begin{abstract}
CARNEIRO, J. L. V. Evaluation of the role of miRNAs -221, -222 e -4728-3p in breast cancer stem cells derived from HER2+ cell lines. 2013. $122 \mathrm{p}$. Ph. D. thesis (Biotechnology) - Instituto de Ciências Biomédicas, Universidade de São Paulo, São Paulo, 2013.
\end{abstract}

Studies have shown that a small population of breast tumor cells, called cancer stem-cells (CSCs), are highly tumorigenic when injected in immunodeficient mice. These CSCs, characterized by high expression levels of CD44, low or undetectable levels of CD24 $\left(\mathrm{CD} 44^{+} \mathrm{CD} 24^{-/ \text {low }}\right)$ and a high activity of aldehyde dehydrogenase (ALDH1), contribute to tumor agressivity, metastatization as well as radio and chemotherapy resistance. These CSCs appear to express the embryonic stem cell markers OCT-4, NANOG, SOX2, KLF4, LIN28, which could be found in CSCs. The enrichment of CSCs in HER+ breast tumors suggests that this oncogene may trigger it's more agressive behaviour when compared to tumors with no HER2 amplification. Some miRNAs are differentially expressed in stem cells, suggesting their putative role in regulation of the biology of these cells. Previous studies have shown miRNA-221 and -222 to be upregulated in breast CSCs when compared to differentiated cells, as well as the high levels of miRNA-4728-3p, (mapped in an intron of HER2) in HER2+ tumors and cancer cell lines. In this study, we aim to contribute to the better understanding the role of miRNAs $-221,222,4728-3 p$ in the the biology of CSCs in breast cancer cell lines. Firstly, experiments were done in breast cancer cells derived from patients as well as MCF-7 cells (grown adherent or as mammospheres). When compared to cells grown in adherent conditions, mammospheres showed higher levels of miRNAs -221 and -222 , CD44, OCT-4, $N A N O G$ and $S O X 2$ and also, reduced CD24 levels. The mammosphere forming efficiency (MFE) of MCF-7 cells was increased after lentiviral-induced miR-221 and -222 overexpression. The resistance to paclitaxel was increased in mammopheres that were overexpressing miRNA-222. Together, these results suggested a possible role of these miRNAs in MCF-7-derived CSCs. Subsequently, OCT-4, NANOG, SOX2, KLF4, LIN28, as well as miRNAs -221, -222, -4728-3p were evaluated by qRT-PCR in mammospheres (cultivated for 7, 14, 21 and 28 days) from HER+ cell lines, BT-474 e SKBR3, and MFC-7. ALDH1, CD44 and CD24 were evaluated in mamospheres from these cell lines by flow cytometry. The phenotype $\mathrm{CD} 44^{+} \mathrm{CD} 24^{- \text {low }}$ was not increased in 7-days mammospheres, a finding that may derived from the association of this phenotype with CSCs with basal/mesenchymal profile. Although miRNAs -221, -222, -4728-3p and OCT-4, NANOG, $S O X 2$, KLF4, LIN28 were not found to be increased in mammospheres during all periods of culture, mammospheres in culture for 7 days showed high levels of ALDH1, a "gold standard" stem cell marker for isolating subpopulations of CSCs in HER+ cells lines. This result suggests an enrichment of CSCs in mammospheres from HER+ cell lines, BT-474 and SKBR3, as well as in MCF-7. A superexpression of miR-4728-3p, located in an intron of the HER2 gene, induced the increment of ALDH1+ subpopulations in two cell lines, reinforcing its role in the biology of CSCs.

Keywords: Cancer stem cells. Breast cancer. miR-221. miR-222. miR-4728-3p. 


\section{LISTA DE ILUSTRAÇÕES}

Figura 1 Eficiência de Formação de mamosferas em função de HER2.

Figura 2 Mapa linearizado do lentivetor tween com sequência do miR-221

Figura 3 Culturas da linhagem celular MCF-7 em monocamada aderente e em condição de formação de mamosferas

Figura 4 Avaliação da expressão gênica de marcadores de pluripotência de células-tronco embrionárias SOX2, OCT4 e NANOG em linhagem MCF-7 ou células derivadas de tumores primários de três pacientes $(208,308$ e 708$)$

Figura 5 Avaliação da expressão endógena de miR-221 e -222 em células MCF7 e células derivadas de tumores primários de três pacientes $(208,308$ e 708).

Figura 6 Expressão relativa de miR-221 e -222 em células MCF-7 derivadas de culturas de mamosferas transduzidas com construtos para a superexpressão de miR-221 e -222.

Figura 7 Avaliação da eficiência de formação de mamosferas na linhagem celular MCF-7 transduzida com construtos para a superexpressão de miR-221 e -222

Figura 8 Avaliação da resistência à apoptose em cultura de mamosferas de células MCF-7 superexpressando miR-221 ou -222 e tratadas com paclitaxel.

Figura 9 Mapas de lentivetores de terceira geração baseados em HIV contendo insertos para a superexpressão de miRNAs precursores. 
Figura 10 Esquema ilustrando o lentivetor usado para produção dos miRNAs precursores.

Figura 11 Mapas funcionais dos plasmídeos contidos no pPACKH1 Packaging Plasmid Mix

Figura 12 Cultura de mamosferas e de células aderentes derivadas das linhagens MCF-7, SKBR3 e BT-474.

Figura 13 Variação da expressão dos genes ACTB, GAPDH, GUSB, HPRT e HuPO entre as linhagens estudadas

Figura 14 Variação da expressão dos genes RNAs (snoRNAs): RNU44, RNU48 e o small nuclear RNA (snRNA): RNU6B entre as linhagens estudadas.

Figura 15 Análise da expressão relativa dos genes SOX2, OCT4, NANOG, LIN28 e KLF4 em células das linhagens MCF-7, BT-474 e SKBR3 aderentes e derivadas de mamosferas

Figura 16 Porcentagem das populações $\mathrm{CD}^{-} / \mathrm{CD} 24^{+}, \mathrm{CD} 44^{+} / \mathrm{CD} 24^{+}$, $\mathrm{CD}^{+} 4^{+} / \mathrm{CD} 24^{-}, \mathrm{CD}_{4} 4^{-} / \mathrm{CD} 24^{-}$em células aderentes e derivadas de mamosferas de 1a geração das linhagens MCF-7, BT-474 e SKBR3.

Figura 17 Dot plots representativos dos percentuais de células ALDH1+ entre as células aderentes e derivadas de mamosferas das linhagens MCF7, BT-474 e SKBR3 na presença ou na ausência de DEAB

Figura 18 Percentuais de células ALDH1+ entre células aderentes e derivadas de mamosferas das linhagens MCF-7, BT-474 e SKBR3 
Figura 19 Expressão endógena de HER2 nas células wild-type aderentes das linhagens MCF-7, BT-474 e SKBR3.

Figura 20 Análise da expressão endógena relativa de HER2 em células aderentes e derivadas de mamosferas das linhagens MCF-7, BT-474 e SKBR3..

Figura 21 Expressão endógena relativa de miR-221, -222 e -4728-3p nas células wild-type aderentes das linhagens MCF-7, BT-474 e SKBR3.

Figura 22 Análise da expressão endógena relativa de miR-221, -222 e -4728-3p em células aderentes e derivadas de mamosferas das linhagens celulares MCF-7, BT-474 e SKBR3

Figura 23 Imagens fotográficas por microscopia em luz visível e UV da linhagem celular 293T/17 48h após a co-transfecção do plasmídeo controle positivo pSIH1-H1-siLuc-copGFP : pPACKH1 em diferentes proporções

Figura 24 Imagens fotográficas por microscopia em luz visível e UV da linhagem celular 293T/17 após a co-transfecção dos plasmídeos CD516B-mir-222 : pPACKH1 em diferentes proporções, na ausência ou presença de poli-lisina em diferentes tempos

Figura 25 Curva de calibração para titulação viral.

Figura 26 Imagens fotográficas por microscopia em luz visível e UV linhagens celulares MCF-7, BT-474 e SKBR3 transduzidas com lentivetores para a superexpressão de miR-221, -222 e 4728-3p e RFP.

Figura 27 Quantificação de miR-221, -222 e $-4728-3 p$ em células transduzidas. 
Figura 28 Dot plots representativos da porcentagem de células ALDH1+ entre as células aderentes das linhagens MCF-7, BT-474 e SKBR3 transduzidas com os construtos scr, $-221,-222$ e $-4728-3 p \ldots \ldots \ldots \ldots \ldots \ldots . . . . .101$

Figura 29 Percentuais de subpopulações ALDH+ em linhagens wt, controle e em células com superexpressão de miR-221, -222 e -4728-3p.

Figura 30 Índices celulares calculados por impedância em intervalos de 1 hora em células BT-474 superexpressando miR-221, -222 e -4728-3p........

Figura 31 Valores de slope calculados em um intervalo de $34 \mathrm{~h}$ em células BT474 com superexpressão de miR-221, -222 e -4728-3p

Figura 32 Valores de IC50 do quimioterápico paclitaxel em células wt das linhagens SKBR3 e BT-474 


\section{LISTA DE QUADROS}

Quadro 1 Sequências de iniciadores usados para a amplificação de mRNAs de interesse.

Quadro 2 Sequências de iniciadores usados para a amplificação de mRNAs de interesse... 


\section{LISTA DE TABELAS}

Tabela 1 Porcentagem de células CD $44^{+}$e CD24 $4^{-/ \text {baixa }}$ em células aderentes e derivadas de mamosferas da linhagem MCF-7 ............................ 44

Tabela 2 Análise da eficiência de infecção com vetores lentivirais para a superexpressão dos miRNAs -221 e -222 em células MCF-7 aderentes. 


\section{LISTA DE ABREVIATURAS E SIGLAS}

ACTB - Gene que codifica a proteína beta-actina

Akt1 - Proteína quinase serina/treonina

ALDH - Aldeído desidrogenase (do Inglês Aldehyde Dehydrogenase)

ALDH1 - Isoforma 1 da aldeído desidrogenase, também conhecida como ALDH1A1

ARGONAUTA-2 - Proteína responsável pela clivagem dos mRNAs-alvo de miRNAs

ATCC - American Type Culture Collection

ATP - Adenosina trifosfato de potássio

B-27 - Suplemento substituto de soro em culturas celulares

BAC - Cromossomo artificial de bactéria

bFGF - Fator de crescimento fibroblástico básico (do Inglês Basic Fibroblast Growth Factor)

BMI-1 - Gene envolvido na auto-renovação ( do Inglês B lymphoma mouse Moloney

leukemia virus insertion region 1)

CD24 - Proteína de adesão celular (do Inglês cluster of differentiation)

CD44 - Glicoproteína transmembrana (do Inglês cluster of differentiation)

CKs - Citoqueratinas (do Inglês cytokeratins)

CSCs - Células tronco tumorais (do Inglês Cancer Stem Cells)

DCIS - Carcinoma de mama ductal in situ (do Inglês Ductal Carcinoma in Situ)

DEAB - Dietilaminobenzaldeído, inibidor da ALDH

DICER - Enzima nuclease que cliva moléculas de RNA dupla fita

DNase - Enzima que cliva DNA

DROSHA - Ribonuclease 3, envolvido no processamento de pri-miRNAs

EDTA - Àcido etilenodiaminotetracético

EGF - Fator de crescimento epidermal (do Inglês Epidermal Growth Factor)

EGFR - Receptor do Fator de crescimento epidermal (do Inglês Epidermal Growth Factor Receptor)

EMT - Transição epitélio-mesênquima (do Inglês Epithelial-mesenchymal transition)

ER - Receptor de estrógeno (do inglês Estrogen Receptor)

FBS - Soro fetal bovino (do inglês Fetal Bovine Serum)

GAPDH - Gene que codifica a gliceraldeído-3-fosfato desidrogenase

gDNA - Àcido desoxirribonucleico genômico

GFP - Proteína fluorescente verde (do Inglês Green fluorescence protein) 
GUSB - Gene que codifica a beta-glucuronidase

HEDGEHOG - Via de sinalização

HER2+ - Termo usado para designar células ou tumores que possuem superexpressão do receptor HER2

HER2 - Receptor do fator de crescimento epidermal tipo 2 (do Inglês Human Epidermal Growth Factor Receptor 2)

HER2 - Gene que codifica para o receptor HER2

HIV - Vírus da imunodeficiência humana (do Inglês human immunodeficiency virus)

HPRT - Gene que codifica a hipoxantina-guanina fosforribosil transferase

HuPO - Gene que codifica a proteína ribossomal ácida humana

IGFR - Receptor do fator de crescimento similar à insulina (do Inglês Insulin-like Growth Factor 1 Receptor)

iPS - Célula-tronco pluripotente induzida (do Inglês Induced Pluripotent Stem cells)

KLF4 - Fator de transcrição (do Inglês Krueppel-like factor 4)

LIN28 - Gene que codifica para a proteína homóloga LIN-28

MAPK - Proteína quinase ativada por mitógeno (do Inglês Mitogen-activated protein kinase)

MFE - Eficiência de formação de mamosferas (do Inglês Mammosphere-forming efficiency)

miR - MicroRNA

miRNA - MicroRNA

mRNA - Ácido ribonucleico mensageiro

mTOR - - Proteína alvo da rapamicina em mamíferos (do Inglês mammalian target of rapamycin)

MUC4 - Gene que codifica a proteína mucina 4 Proteína alvo da rapamicina em mamíferos (do Inglês mammalian target of rapamycin)

MTT - Brometo de 3-[4,5dimetil-tiazol-2-il]-2,5-difenil-tetrazólio).

NAD - Nicotinamida adenina dinucleotídeo

NANOG - Fator de transcrição envolvido na auto-renovação de células-tronco embrionárias

NOD/SCID - do Inglês non-obese diabetic mice/Severe Combined Immunodeficiency

NOTCH - família de proteínas transmembrana

OCT4 - do Inglês Octamer-binding Transcription Factor 4), fator de transcrição também conhecido como POU5F1 (POU domain, class 5, transcription factor 1).

PI3K - Fosfatidilinositol 3-quinase (do Inglês Phosphatidylinositide 3-kinase)

PB - Pares de bases

PBS - Tampão fosfato salina (do Inglês Phosphate Buffered Saline) 
PCR - Reação em cadeia da polimerase (do Inglês Polymerase Chain Reaction)

PTEN - do Inglês Phosphatase and Tensin homolog

PR - Receptor de progesterona (do Inglês Progesterone Receptor)

pre-miRNA - miRNA precursor

pri-miRNA - miRNA primário

qRT-PCR - PCR quantitativo em tempo real

RARs - Receptores de ácido retinóico

RFP - Proteína fluorescente vermelha (do Inglês Red fluorescence protein)

RISC - Complexo de silenciamento induzido por RNA (do inglês RNA-induced silencing complex)

RT - Reação da transcrição reversa (do Inglês reverse trasncription)

RTK - Receptor do tipo tirosina quinase (do Inglês receptor tyrosine kinase)

siRNAs - do Inglês small interfering RNA

snRNA - do Inglês small nuclear RNA

snoRNAs - do Inglês small nucleolar RNA

SONIC - Subgrupo de ligantes de Hedgehog

SOX2 - Fator de transcrição, também conhecido como SRY-box2 (Sex Determining Region Y-box containing protein 2)

Tcl1 - Proto-oncogene, quinase Akt coativadora (do Inglês T Cell Leukemia/Lymphoma 1)

TRPS1 - Gene conhecido pela mutação característica da síndrome trico-rino-falangeal, tipo 1 (do Inglês tricho-rhino-phalangeal syndrome type 1)

Tzb - Trastuzumabe - anticorpo monoclonal recombinante humanizado anti-Her2

WNT - Grupo de vias de transdução de sinais

WPRE - Sequência de DNA (do inglês Woodchuck Hepatitis Virus - WHP-

Posttranscriptional Regulatory Element)

WT - do Inglês wild-type

ZEB2 - Gene que codifica o fator de transcrição envolvido na EMT (do Inglês zinc finger Ebox-binding homeobox2). 


\section{SUMÁRIO}

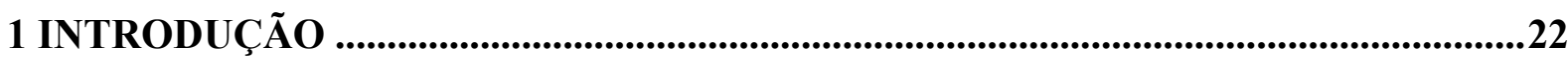

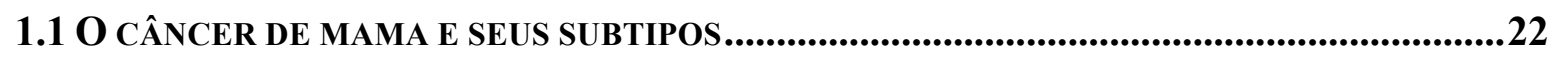

1.1.1 Tumores de mama do subtipo ductal invasivo HER2+.....................................23

1.2 CÉlULAS-TRONCO TUMORAIS (CSCS).................................................................25

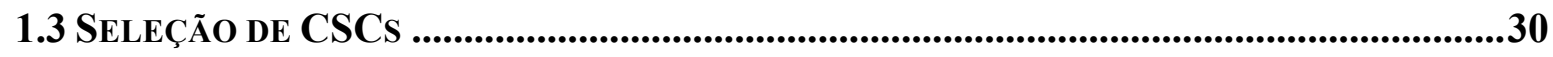

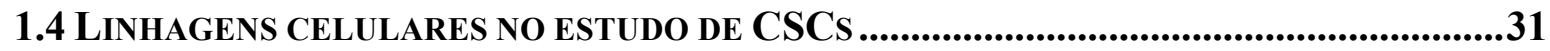

1.5 O CULTIVO DE CÉLULAS-TRONCO EM CONDIÇÕES NÃO-ADERENTES...........................32

1.6 MIRNAS EM CÉLULAS-TRONCO TUMORAIS DE TUMORES DE MAMA...........................33

2 CAPÍTULO I - EXPRESSÃO DE MIRNAS -221 E 222 EM CÉLULAS-TRONCO

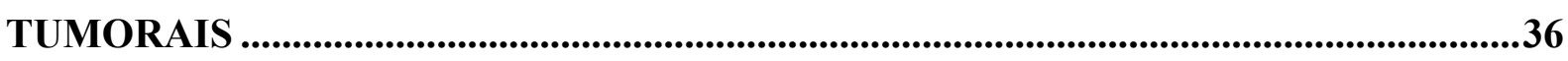

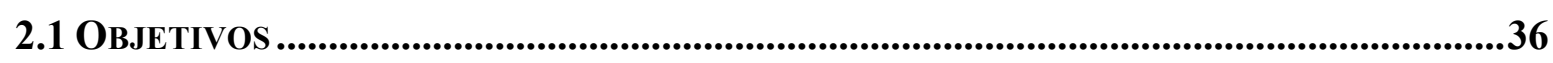

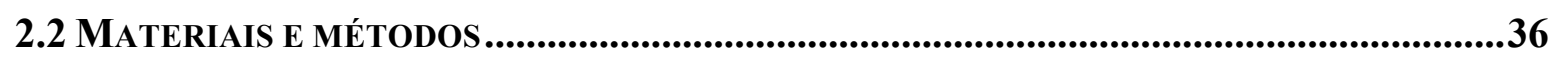

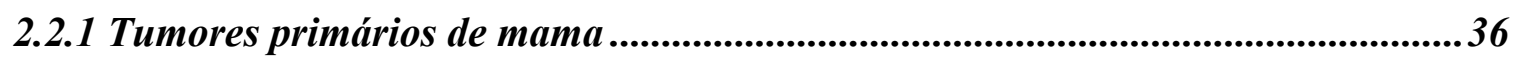

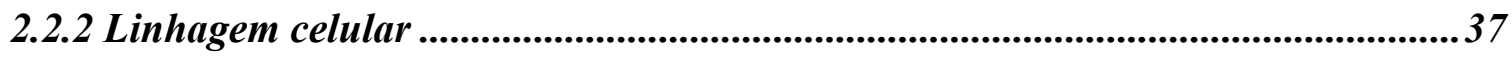

2.2.3 Cultura de mamosferas .................................................................................... 37

2.2.4 Análise dos marcadores CD44 e CD24 por citometria de fluxo ............................37

2.2.5 Extração de RNA, transcrição reversa e PCR quantitativo em tempo real ........... 37

2.2.6 Lentivetores baseados em HIV e superexpressão dos miRNAs ...........................39

2.2.7 Eficiência de formação de mamosferas...................................................................39

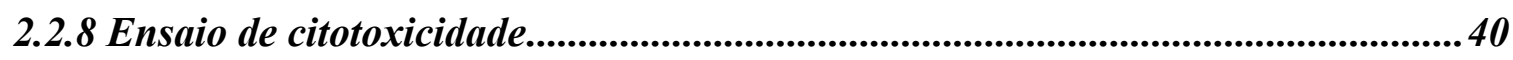

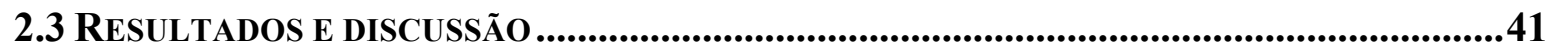

2.3.1 Formação de mamosferas.........................................................................41

2.3.2 Avaliação da expressão de marcadores de pluripotência ....................................42

2.3.3 Avaliação dos marcadores de CSCs de mama...........................................................44

2.3.4 Avaliação da expressão endógena dos miRNAs -221 e -222 ................................ 45

2.3.5 Avaliação da superexpressão dos miRNAs -221 e -222 em MCF-7................... 47

2.3.6 Eficiência de formação de mamosferas após superexpressão de miR-221 e -222

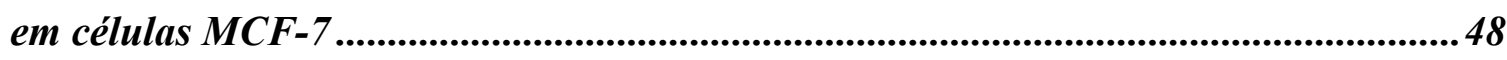

2.3.7 Resistência à morte celular na presença de paclitaxel após superexpressão dos miRNAs -221 e -222 em células MCF-7 ..................................................................49

3 CAPÍTULO II - PAPEL DOS MIRNAS -221, -222 E -4728 EM CÉLULAS-TRONCO

HER2+ 
3.1 OBJETIVOS

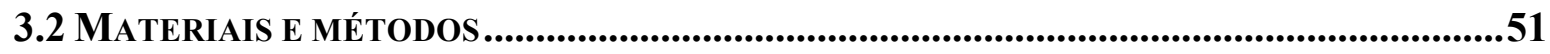

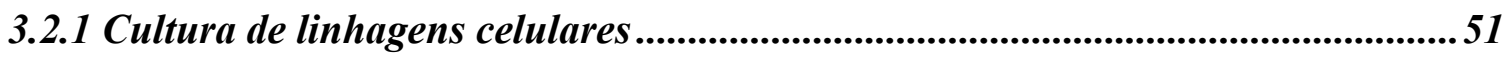

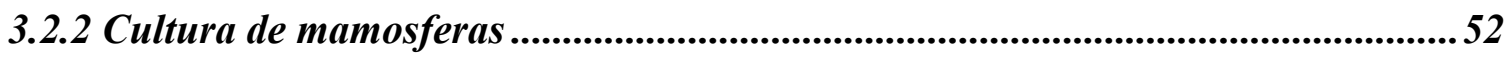

3.2.3 Citometria de fluxo ..................................................................................................................52

3.2.4 Extração de RNA, transcrição reversa e PCR em tempo teal................................54

3.2.5 Superexpressão dos miRNAs ..............................................................................56

3.2.5.1 Características dos lentivetores baseados em HIV ............................................56

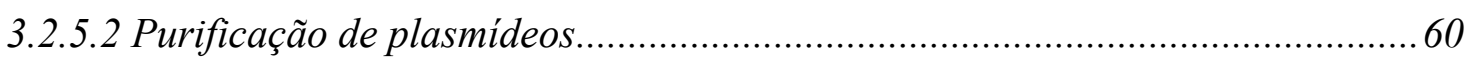

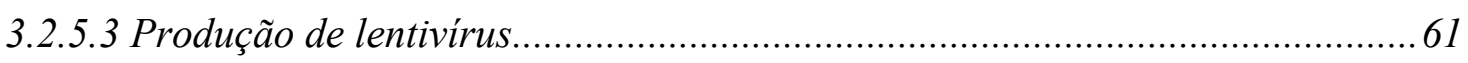

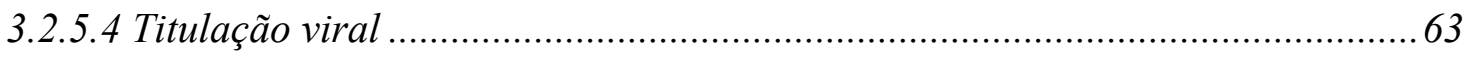

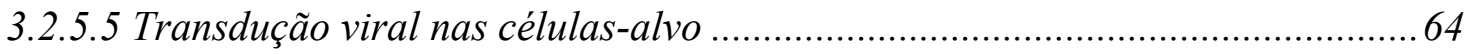

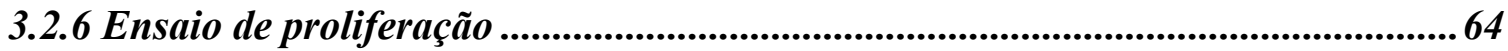

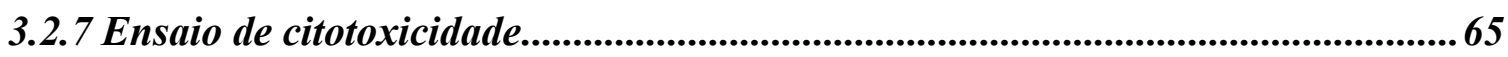

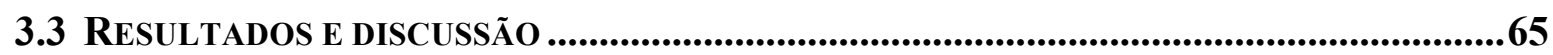

3.3.1 Características morfológicas de mamosferas derivadas de linhagens celulares de

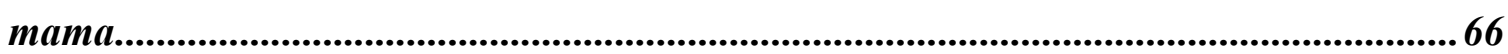

3.3.2 Análises da expressão endógena de genes de interesse .......................................67

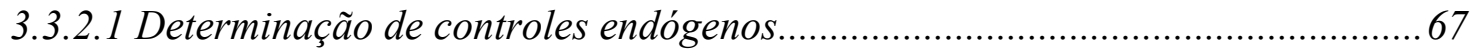

3.3.2.2 Expressão de marcadores de pluripotência em mamosferas .............................69

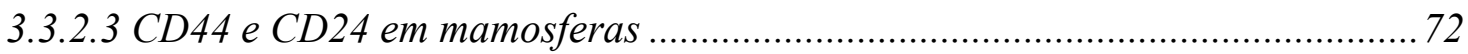

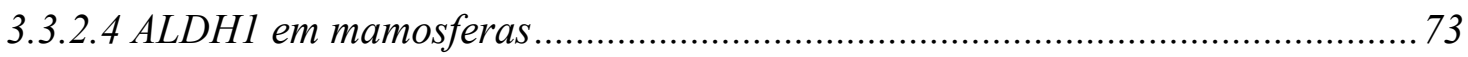

3.3.2.5 Expressão endógena de HER2 em células aderentes e mamosferas.................. 79

3.3.2.6 Expressão dos miRNAs -221, -222 e-4728-3p em células aderentes e

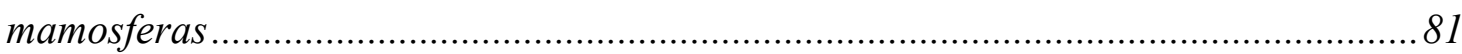

3.3.3 Superexpressão dos miRNAs em linhagens utilizando construtos lentivirais...... 84

3.3.3.1 Determinação da proporção dos plasmídeos na co-transfecção ....................... 84

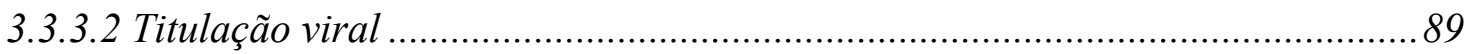

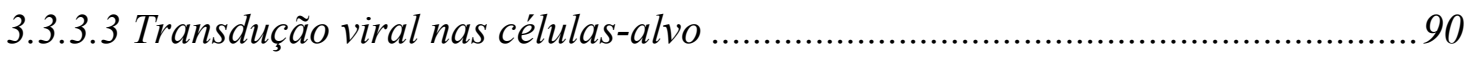

3.3.3.4 Expressão dos miRNAs após transdução com lentivetores ............................... 94

3.3.4 Análise e separação da subpopulação $\mathrm{ALDH}^{+}$após indução da superexpressão de

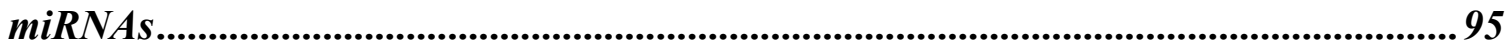

3.3.5 Ensaio de proliferação em células BT-474 transduzidas..................................102

3.3.6 Ensaio de citotoxicidade................................................................................. 104 


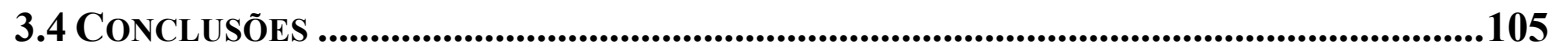

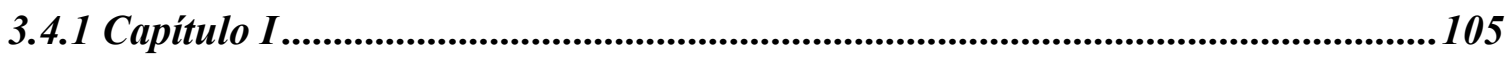

3.4.2 Capítulo II.................................................................................................................. 105

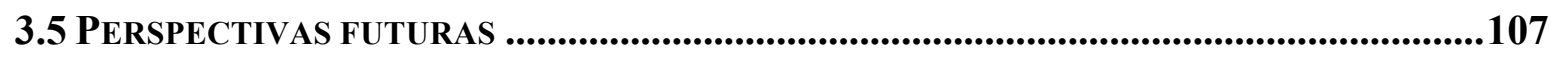

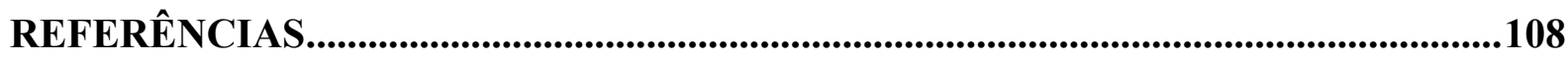




\section{PREFÁCIO}

Esta tese foi organizada em dois capítulos.

O primeiro capítulo corresponde ao trabalho inicial do doutorado, o qual envolveu o estudo dos microRNAs -221 e -222 em células-tronco tumorais derivadas de linhagem e de pacientes com câncer de mama. Este estudo foi desenvolvido durante meu doutorado sanduíche realizado no Laboratório de Biologia Celular e Molecular da Dra. Gerolama Condorelli da Università Degli Studi di Napoli Federico II, na Itália, através do programa de bolsas europeu Erasmus Mundus External Cooperation Window. Esta etapa transcorreu entre os meses de Agosto de 2010 até Junho de 2011.

O segundo capítulo corresponde ao trabalho realizado no Laboratório de Genômica Médica no Centro Internacional de Pesquisas e Ensino (CIPE) do AC Camargo Cancer Center, em São Paulo. Neste capítulo, o foco do estudo foram microRNAs em células-tronco tumorais de mama derivadas de linhagens HER2+. Com apoio financeiro da FAPESP, esta etapa teve início em meados de Janeiro de 2012. Aumentamos o painel de células estudadas em relação ao período inicial e incluímos mais um miRNA, recentemente descrito, localizado em um íntron de HER2.

Sendo assim, a tese possui uma única Introdução, pois o tema é comum entre os dois capítulos. Em seguida da Introdução, os capítulos são apresentados cada qual com seus Objetivos, Materiais/Métodos e Resultados/Discussão. Por último, segue a Conclusão final contendo os principais achados de cada capítulo e as perspectivas futuras para a continuidade deste trabalho. 


\section{INTRODUÇÃO}

\subsection{Oâncer de mama e seus subtipos}

O câncer de mama é a principal causa de morte no sexo feminino depois das doenças cardiovasculares, tais como o infarto e o acidente vascular cerebral, e apresenta a segunda maior taxa de mortalidade no mundo quando comparado com outros tipos de tumores (INTERNATIONAL AGENCY FOR RESEARCH ON CANCER, 2012). A previsão de novos casos para o ano de 2012, em todo o mundo, foi de 1,6 milhão (IARC, 2012).

O câncer de mama é uma doença heterogênea causada por diversas alterações moleculares que podem ocorrer em diferentes tipos celulares (PEROU et al., 2000; SORLIE et al., 2001; SOTIRIOU et al., 2003; WEIGELT et al., 2009). A maioria dos carcinomas de mama (50-80\%) é classificada como ductal-invasivo.

Os tumores de mama invasivos possuem várias formas e estágios, e se caracterizam pela disseminação das células tumorais para outras partes desta glândula, ou para outras regiões do corpo. Tradicionalmente estes tumores são classificados em subgrupos conforme seu grau e tipo histológico, presença de invasão linfo-vascular, metástase para os linfonodos e expressão de alguns marcadores preditivos, tais como os receptores hormonais (estrógeno ER e progesterona - PR) e o receptor do fator de crescimento epidermal tipo 2 (ERBB2 ou HER2) (SORLIE et al., 2001).

Devido à alta heterogeneidade encontrada entre os tumores de mama, a classificação baseada no perfil molecular é uma alternativa atual em relação à classificação anatomopatológica, uma vez que tumores com o mesmo grau, estadio e tipo histológico podem apresentar diferentes prognósticos e distintas respostas à terapia (ELSTON et al., 1991).

A classificação molecular proposta por Perou et al. (2000) e por Sorlie et al. (2001) identifica cinco grandes grupos de tumores de mama e é baseada no perfil de expressão gênica: luminal A, luminal B, HER2 positivos (HER2+), basal-like e normal breast-like.

O subtipo luminal A possui geralmente um bom prognóstico, caracterizado principalmente pela expressão do ER e ausência de expressão de HER2 e expressão de citoqueratinas (CKs) características de células epiteliais luminais, como as CKs 7, 8, 18 e 19.

O subtipo luminal B expressa tanto o ER quanto HER2 e tem menor expressão das CKs 7, 8, 18 e 19, possuindo um pior prognóstico.

Os tumores HER2+ possuem superexpressão de HER2 e são negativos para a expressão de ER e PR, e também estão associados a um prognóstico ruim. 
O subtipo basal-like apresenta características de células basais ou mioepiteliais de mama normal e é identificado pela expressão das CKs 5, 6, 14 e 17, e ausência de expressão dos receptores hormonais e HER2. É um subtipo de mau prognóstico que não responde aos tratamentos hormonais e imunoterápicos disponíveis.

Os tumores normal-breast like apresentam um perfil de expressão gênica similar ao do tecido adiposo e de outras células não-epiteliais, sendo de crescimento lento e pouco agressivo. Geralmente possuem bom prognóstico, apesar de também não responderem ao tratamento hormonal e imunoterápico devido à ausência de expressão de ER e PR e HER2. Os dois últimos subtipos apresentados são frequentemente agrupados em uma classe chamada de tumores triplo-negativos, devido à ausência de expressão dos receptores hormonais e HER2. Além dos cinco grandes grupos acima, existem alguns tumores que sobrepõem dois grupos, tais como os tumores HER2+ com expressão de CKs basais 5 e 6 , chamados de basal HER2+ esses tumores são tipicamente pouco diferenciados, possuem alto grau de invasão com grande necrose (OLIVERAS-FERRAROS et al., 2010).

Apesar dessas classificações moleculares dos tumores terem contribuído com maior valor preditivo da evolução e da resposta ao tratamento em relação à classificação histopatológica clássica, tumores com a mesma classificação histológica e molecular podem ter prognóstico e evolução da doença muito distintos.

\subsubsection{Tumores de mama do subtipo ductal invasivo HER2+}

HER2 é uma proteína codificada pelo proto-oncogene $H E R 2$ (ERBB2/C- ou $E R B B 2 / N E U)$, que se localiza em um bloco genômico de cerca de 30 mil bases, no cromossomo 17. Esta proteína é um receptor do tipo tirosina quinase (RTK), membro da família dos receptores de crescimento epidermal (EGFR), que compreende: HER1 (EGFR), HER2 (ERBB2), HER3 (ERBB3) e HER4 (ERBB4) (ANDRÉ et al. 2005; POLANOVSK; LEBEDENKO; DEYEV, 2012). Todos os membros da família possuem um domínio extracelular de ligação, uma única região transmembrana e um domínio citoplasmático tirosina quinase (HYNES; LANE, 2005). HER2 forma heterodímeros com os outros três membros da família EGFR, compondo diferentes complexos que levam à fosforilação cruzada nos resíduos de tirosina, ativando cascatas de transdução de sinal e ativação de várias vias de sinalização. As principais vias ativadas pela heterodimerização de ERBB2 e ERBB3, são as de MAPK, PI3K/Akt e mTOR, (HYNES; MACDONALD, 2009; POLANOVSK; LEBEDENKO; DEYEV, 2012). 
Os tumores HER2+, compreendem cerca de 15-30\% de todos os tumores de mama, ou 20-25\% dos tumores invasivos. Sua amplificação ou superexpressão em tumores de mama invasivos contribui consideravelmente para sua transformação maligna, pois pacientes com este subtipo tumoral têm o dobro de taxa de mortalidade, quando comparados com aqueles sem a superexpressão deste oncogene (MOASSER, 2007; ROSS et al., 2003; SLAMON et al., 1987). Assim, os tumores de mama HER2+ estão entre os mais agressivos e de pior prognóstico quando não tratados adequadamente (SLAMON et al., 1987).

HER2 é importante na biologia do câncer de mama. Um exemplo está nas consequências de sua transfecção na linhagem celular MCF7 (que expressa ER), que tem como consequência um aumento na proliferação celular, maior potencial de invasão e um potencial metastático elevado (ROSS et al., 2003). Além disto, existe uma correlação entre o comportamento agressivo das linhagens celulares HER2+ e a observação clínica de tumores HER2+, que são associados com um pior prognóstico na ausência de terapia (MOASSER, 2007).

Existem duas principais classes de inibidores de HER2: anticorpos monoclonais simples e conjugados que se ligam diretamente no domínio extracelular de HER2 e inibidores de tirosina quinase que competem com o ATP (adenosina trifosfato de potássio) no domínio tirosina quinase do receptor (HYNES; LANE, 2005).

Tumores HER2+ tem forte indicação clínica para o uso de trastuzumabe (tzbanticorpo monoclonal recombinante humanizado anti-HER2) em estágios precoces ou metastáticos do câncer de mama (WOLFF et al., 2007). A terapia adjuvante com tzb, testada em cinco estudos prospectivos randomizados, mostrou que o tratamento reduziu o risco de recorrência em $50 \%$ e diminuiu em $30 \%$ o risco de morte em pacientes com tumores HER2+ (IZUMI et al., 2002; ROMOND et al., 2005; PICCART-GEBHART et al., 2005). No entanto, nem todos os tumores HER2+ respondem ao tratamento com tzb, e alguns mecanismos de resistência à droga já foram demonstrados in vitro, tais como: a deficiência de PTEN (PANDOLFI, 2004); a superexpressão de outros receptores de superfície, como o receptor do fator de crescimento similar a insulina (IGFR) (LU et al., 2001); o perfil de tumores basais HER2+ (HARRIS et al., 2007); ou a presença de mucina 4 (MUC4) na superfície celular (MOASSER, 2007). Na ocorrência de metástases apenas um terço das pacientes que superexpressam HER2 respondem a tzb. Muitas pacientes tratadas com drogas anti-HER2 vão desenvolver resistência ao tratamento, apesar de terem apresentado uma resposta positiva no início da terapia. Da mesma forma, a maioria das pacientes com doença metastática com boa resposta inicial anti-HER2, mostra progressão da doença em apenas um ano após o início do 
tratamento. A terapia do tzb em combinação com paclitaxel (SEIDMAN et al., 2001) ou docetaxel (SLAMON et al., 2001) pode aumentar a resposta ao tratamento, tempo de progressão da doença e sobrevida quando comparado com a monoterapia do tzb (NAHTA; ESTEVA, 2006).

Deste modo, a resistência à droga e a ocorrência de metástases tumorais representam os principais obstáculos para o sucesso do tratamento deste tipo de câncer (VOGEL, 2002). Por isso, a estratégia da combinação com outras drogas em um mesmo tratamento com tzb geralmente é adotada (HYNES; LANE, 2005).

Estudos recentes sugerem que a resistência clínica ao tzb e a outras terapias que têm como alvo o receptor HER2, é devida à presença das chamadas células iniciadoras de tumores, também conhecidas como células-tronco tumorais (CSCs) em tumores HER2+ (revisado por BEDARD; CARDOSO; PICCART-GEBHART, 2009). Alguns possíveis mecanismos de resistência ao tzb envolvem muitos dos mesmos marcadores que têm sido descritos na biologia de células-tronco tumorais. A perda ou bloqueio do sítio de ligação do tzb no domínio extracelular de HER2 parece estar relacionada à expressão aumentada do marcador de célula-tronco CD44 (revisado por BEDARD; CARDOSO; PICCARTGEBHART, 2009). Outro mecanismo de resistência é a ativação da sinalização via NOTCH, que leva ao aumento da capacidade de auto-renovação/proliferação de células progenitoras, tanto in vivo como in vitro, (ANDROUTSELLIS-THEOTOKIS et al., 2006) ou à indução da transição epitélio-mesênquima (EMT) (revisado por BEDARD; CARDOSO; PICCARTGEBHART, 2009).

\subsection{Células-tronco tumorais (CSCs)}

O conceito de que o câncer surge a partir de células-tronco ou "células germinativas" foi primeiramente proposto há 150 anos (GINESTIER et al., 2007), mas apenas recentemente os avanços no conhecimento da biologia destas células permitiram o desenvolvimento de abordagens experimentais necessária para uma maior investigação desta hipótese (REYA et al., 2001; SELL, 2004).

De acordo com os modelos clássicos de carcinogênese, os eventos que resultam na geração de um tumor podem ocorrer em qualquer célula. Nesse modelo a desregulação que leva ao crescimento exacerbado dos tumores é atribuída a uma série de alterações genéticas sequenciais e cumulativas, que resultam na ativação de genes responsáveis pela proliferação celular e no silenciamento de genes que inibem a proliferação e a morte celular (ISAAC, 
1993; LOWE; LIN, 2000). Porém, de acordo com a hipótese das células-tronco tumorais (CSC), os alvos preferenciais da transformação oncogênica devem ser as células-tronco, ou células progenitoras em um nível precoce de diferenciação (BONNET; DICK, 1997; GLINSKY, 2007; JAISWAL et al., 2003, KRIVTSOV et al., 2006). Neste modelo, os tumores contêm populações celulares heterogêneas, incluindo um pequeno subgrupo distinto de células, formado pelas CSCs, as quais possuem a habilidade de iniciar e manter o crescimento tumoral, além de promover o surgimento de metástases (AL-HAJJ; CLARKE, 2004; CREIGHTON et al., 2009; LI et al., 2008; NICOLINI et al., 2011; PHILLIPS et al., 2006; VAN RHENEN et al., 2005). Importantes evidências sugerem que as CSCs sejam responsáveis pela progressão e pela recorrência tumoral (CLARKE; FULLER, 2006; LYNCH; CARIATI; PURUSHOTHAM, 2006; POLYAK et al., 2006; WEISSMAN et al., 2005; WICHA et al., 2006), além de serem muito importantes em fases posteriores nas quais ocorrem resistência à terapêutica (AL-EJEH et al., 2011; FRAME; MAITLAND, 2011; HU; FU; 2012; LI et al., 2008; LIU; WICHA, 2010).

De acordo com a hipótese de CSCs, tumores são originados a partir mutações em células-tronco ou células progenitoras normais, as quais levam a uma alteração dos genes que regulam o processo normal de auto-renovação (MOLOFSKY; PARDAL; MORRISON, 2004; PASSEGUÉ et al., 2003). Algumas das vias controladas por estes genes incluem: Bmi-1, Notch, Wnt e Sonic Hedgehog (AUSTIN et al., 1997; BHARDWAJ et al., 2001; LIU et al., 2006; SPINK; POLAKIS; WEIS, 2000; TAIPALE; BEACHY et al., 2001). Dois argumentos básicos sustentam a hipótese de que células-tronco tumorais se originam a partir de célulastronco normais. Primeiro, considerando que o desenvolvimento tumoral é o resultado do acúmulo de alterações genéticas sequenciais e progressivas, células-tronco adultas seriam alvos ideais para a transformação maligna inicial devido a sua meia-vida ser muito mais longa em comparação com células diferenciadas (VERMEULEN et al., 2008). Além disto, CSCs compartilham propriedades com células-tronco normais, tais como a capacidade de autorenovação e de diferenciação (BIXBY et al., 2002; PONTI et al., 2005; VERMEULEN et al., 2008). Auto-renovação é o processo pelo qual células-tronco geram progenitores idênticos a elas mesmas, uma propriedade que pode levar à tumorigenicidade, recorrência e metástase (REYA et al., 2001). As células-tronco também se diferenciam para gerar progenitores multipotentes, os quais por sua vez, dão origem a progenitores comprometidos e células diferenciadas. Nas CSCs essa propriedade leva à heterogeneidade populacional de células tumorais, uma característica de quase todos os tipos de câncer (AL-HAJJ; CLARKE, 2004). Deste modo, as células diferenciadas que constituem a massa tumoral, não devem ser 
tumorigênicas, pois não possuem capacidade de auto-renovação e apresentam potencial limitado de proliferação (DEAN; FOJO; BATES, 2005; PARDAL; CLARKE; MORRISON, 2003; REYA et al., 2001).

Evidências experimentais que deram suporte à hipótese de CSCs surgiram pela primeira vez em 1997 (BONNET; DICK, 1997) quando foi demonstrado que leucemias humanas são geradas a partir de uma pequena população de células-tronco leucêmicas capazes de reproduzir a doença em camundongos NOD/SCID (BONNET; DICK, 1997). Estas evidências também foram encontradas em tumores sólidos (AL-HAJJ et al. 2003), quando foi demonstrado que tumores de mama humanos possuem uma subpopulação celular com propriedades de células-tronco. O câncer de mama foi o primeiro carcinoma humano a partir do qual uma subpopulação de células-tronco foi isolada (AL-HAJJ et al., 2003). Originalmente esta população foi caracterizada pela alta expressão de CD44, além de uma expressão baixa ou indetectável de $\mathrm{CD} 24\left(\mathrm{CD} 44^{+} \mathrm{CD} 24^{- \text {baixa }}\right)$. De modo relevante, estas células se mostraram altamente tumorigênicas quando injetadas em camundongos imunodeficientes NOD/SCID.

Alguns trabalhos sugerem que genes associados às células-tronco incluindo LIN28, OCT4, e NANOG podem ter um papel crítico na regulação de CSCs de alguns tumores, tais como câncer de ovário (KWON; SHIN, 2013; PENG; MAIHLE; HUANG, 2010). Pesquisas envolvendo células-tronco pluripotentes induzidas (iPS), suportam a hipótese de que célulastronco são originadas a partir de mecanismos de reprogramação (KRIZHANOVSKY; LOWE, 2009). Esse processo ocorreria através da expressão de um grupo de genes, então chamados de "fatores de reprogramação", células somáticas diferenciadas poderiam ser convertidas em iPS que possuiriam a mesma capacidade de células-tronco embrionárias de dar origem a todos os tipos de tecidos do corpo (YANG et al., 2010). Interessantemente, a maioria desses fatores de reprogramação são superexpressos em certos tipos de tumores humanos e, pelo menos alguns deles, tais como, cMYC, KLF4, SOX2 e LIN28, são estabelecidos como oncogenes (KRIZHANOVSKY; LOWE, 2009). Alguns estudos associam células-tronco tumorais com tais fatores de reprogramação.

A partir de marcadores de superfície característicos, CSCs também têm sido identificadas e isoladas de outros tumores como leucemia mielóide aguda (BONNET; DICK, 1997, HOPE et al., 2004), leucemia mielóide crônica (EISTERER et al., 2005; HOPE et al., 2004), câncer ósseo (GIBBS et al., 2005), câncer cerebral (SINGH et al., 2004a; SINGH et al., 2004b), câncer de próstata (COLLINS et al., 2005), melanoma (FANG et al., 2005), mieloma múltiplo (MATSUI et al., 2004), câncer de cólon (O’BRIEN et al., 2007; RICCI- 
VITIANI et al., 2007), câncer de pâncreas (LI et al., 2007) e câncer de cabeça e pescoço (PRINCE et al., 2007), entre outros.

A resistência à quimioterapia e à radioterapia podem ser devidas à baixa taxa de multiplicação celular, o que também é uma característica que permite distinguir as CSCs de câncer de mama dos outros tipos celulares deste tumor (AL-HAJJ, 2007). As CSCs de tumores de mama também são mais resistentes à radioterapia por possuirem uma maquinaria de reparo de DNA mais eficiente. Da mesma maneira a quimioterapia parece selecionar as CSCs de carcinomas de mama, que resistem ao tratamento (AL-HAJJ, 2007).

Evidências recentes mostram que a tumorigênese, a invasão tumoral e a formação de metástases mediada por HER2 podem ser atribuídas às CSCs presentes em tumores de mama HER2+ (KORKAYA et al., 2008). Korkaya et al. (2008) demonstraram que HER2 regula a população de CSC e de progenitores, levando à tumorigênese e invasão. Foi demonstrado que o tzb reduz a população de CSCs tanto in vivo como in vitro (CHAKRABARTY et al., 2013), além de reduzir a capacidade de formação de estruturas celulares esferoidais com características de células-tronco, conhecidas como mamosferas (KANG et al., 2011). De maneira contrária, a alta expressão de HER2 aumenta a capacidade de formação de mamosferas e também o seu tamanho (KORKAYA et al., 2008).

Em trabalho publicado em 2007, Farnie et al. demonstraram que amostras derivadas de carcinomas de mama ductal in situ (DCIS) HER2+ possuem uma maior eficiência de formação de mamosferas (MFE), quando comparadas com amostras DCIS HER2- (Figura 1). A adição do fator de crescimento epidermal (EGF) foi testada e não alterou a MFE de nenhum dos grupos. No entanto, o uso de gefitinib (inibidor de tirosina quinase de EGFR) foi capaz de reduzir o crescimento das mamosferas HER2+ na ausência de EGF, sugerindo que a droga inibe preferencialmente a atividade de tirosina quinase do heterodímero formado por EGFR/HER2 (FARNIE et al., 2007). Em outro estudo, algumas linhagens celulares tumorais de mama que superexpressam HER2 também possuíam um número maior de CSCs; quando estas células foram injetadas em camundongos, elas se mostraram mais tumorigênicas (MAGNIFICO et al., 2009; ROESLER et al., 2010). 


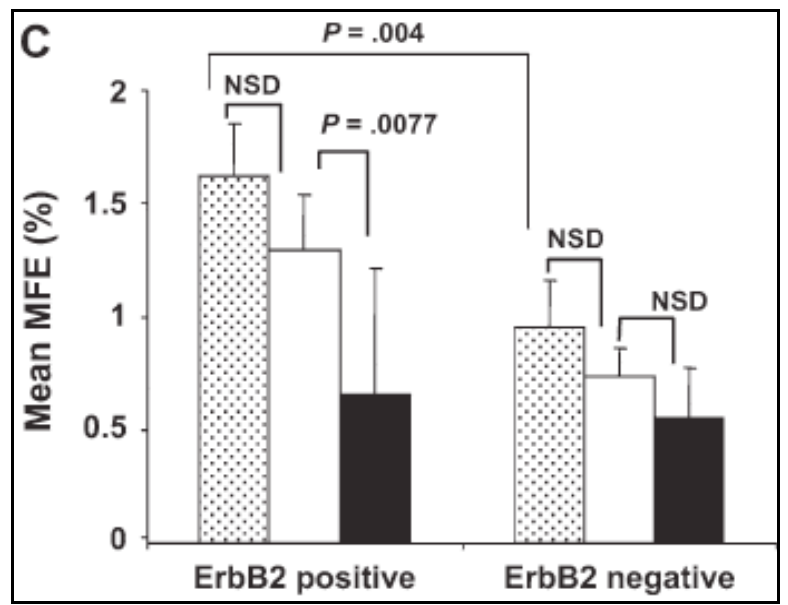

Figura 1 - Eficiência de formação de mamosferas em função de HER2. Amostras HER2+ e HER2- na presença de meio completo para mamosferas contendo EGF (barras pontilhadas), meio sem adição de EGF (barra clara), ou meio completo sem EGF contendo $1 \mu \mathrm{M}$ de gefitinib (barra preta). As barras de erro correspondem a $95 \%$ dos intervalos de confiança. Após a correção de Bonferroni, apenas P-valores $<0,0083$ foram considerados estatisticamente significantes. NSD: sem significância estatística. Fonte: Farnie et al. (2007).

Outro dado interessante é que linhagens celulares de câncer de mama que possuem características de células-tronco, como a formação de mamosferas, possuem alta expressão de HER2 e são mais sensíveis ao tratamento com tzb e lapatinib (droga que inibe a atividade de tirosina-quinase de EGFR e HER2) (ROESLER et al., 2010). Estes resultados sugerem fortemente que as terapias utilizadas no tratamento de tumores de mama HER2+ devam considerar os efeitos da inibição de HER2 na subpopulação de células-tronco presente no tumor. Dados recentes sugerem que em alguns casos a resistência ao tratamento com tzb e a outras terapias que possuem HER2 como alvo pode ser devido à presença de subpopulações de células-tronco nos tumores HER2+. De fato, vários mecanismos possíveis de resistência a tzb também envolvem proteínas características de células-tronco, como no caso da superexpressão do marcador $\mathrm{CD} 44$, capaz de bloquear a ligação de tzb ao domínio extracelular de HER2 (PÁLYI-KREKK et al., 2007). Desta forma, é importante determinar a sensibilidade das subpopulações de células-tronco presentes nos tumores HER2+ frente aos tratamentos a serem empregados, assim como é importante a descoberta de novas drogas que permitam estratégias de tratamento alternativas no caso de relapso da doença, cuja fonte são as CSCs.

Estudos recentes mostraram evidências que sustentam a hipótese de que CSCs possuem fenótipo definido pela célula de origem (sendo estas células-tronco ou células progenitoras em nível precoce de diferenciação) e pelos eventos oncogênicos que contribuíram para a sua transformação (JAMIESON et al., 2004; KELLY et al., 2002). 


\subsection{Seleção de CSCs}

Uma estratégia para encontrar marcadores de células-tronco normais compartilhados com as CSCs é focar o estudo nas funções conservadas de células-tronco e progenitores, já que esses marcadores de função podem estar mantidos nas CSCs. Um marcador candidato que se encaixa nessa descrição é a enzima de detoxificação aldeído desidrogenase 1 (ALDH1).

As aldeído desidrogenases (ALDH) são enzimas que catalisam a oxidação nucleotídeo-dependente (dependente de NAD - nicotinamida adenina dinucleotídeo) mediada por piridina (núcleo estrutural e ativo do NAD), de uma variedade de substratos aldeídos para os seus correspondentes ácidos carboxílicos (DUESTER, 2000; MAGNI et al., 1996; SOPHOS; VASILIOU, 2003; YOSHIDA et al., 1998). Aldeídos são compostos endógenos formados a partir do metabolismo de álcool, vitaminas e aminoácidos, bem como através do metabolismo de compostos exógenos, tais como certas drogas terapêuticas e toxinas ambientais. Enzimas ALDH são necessárias para que os aldeídos possam manter a homeostase e o crescimento celular normal, bem como permitir que as células se adaptem a um ambiente de estresse. Até hoje já foram descritos 19 membros da superfamília de ALDH (MARCHITTI et al., 2008; SLÁDEK, 2003). Duas das isoenzimas humanas mais estudadas são as ALDH1 (ou ALDH1A1) e ALDH2. ALDH1 tem como função principal a oxidação do retinol (vitamina A) em ácido retinóico (CHUTE et al., 2006) que tem um papel crucial na homeostase fisiológica de muitos órgãos e no desenvolvimento normal durante a embriogênese humana (EVANS, 1988; LABRECQUE; BHAT; LACROIX, 1993). ALDH1 é predominantemente expressa no epitélio de testículo, cérebro, olhos, rins e também está altamente expressa em células-tronco/progenitoras hematopoiéticas e neurais humanas e de murinos (ARMSTRONG et al., 2004; CHUTE et al., 2006; HESS et al., 2004; HESS et al., 2006; MARCHITTI et al., 2008; MATSUI et al., 2004). Seu papel nestas células está relacionado com a diferenciação celular via oxidação do retinol em ácido retinóico (COLLINS, 2008). O ácido retinóico ativa receptores de ácidos retinóicos (RARs), que são uma família de fatores de transcrição nuclear dependente de ligante, que regulam a transcrição de genes contendo elementos responsivos ao ácido retinóico (SO; CROWE, 2000).

ALDH1 também possui um papel na detoxificação de certos agentes alquilantes terapêuticos, como a ciclofosfamida e a ifosfamida (SAHOVIC et al., 1988) e, portanto, parece contribuir com as propriedades inatas de resistência à radiação e detoxificação das células-tronco normais (DEAN, FOJO; BATES, 2005). Células tumorais com altos níveis de ALDH1 são resistentes ao efeito citotóxico desses agentes alquilantes citados (DUELLMAN 
et al., 2013). Várias isoformas de ALDH, incluindo ALDH1, são também altamente expressas em células-tronco, CSCs e células do cordão umbilical, quando comparadas com tipos celulares diferenciados (ALISON et al., 2010; BALBER, 2011; D'ANGELO; WICHA, 2010; GENTRY et al., 2007; GINESTIER et al., 2007; JIANG et al., 2009; MA; ALLAN, 2011; MOREB, 2008).

A atividade da ALDH1 é avaliada em ensaios in vitro, como o Aldefluor ${ }^{\circledR}$ e o Aldecount ${ }^{\circledR}$ (Stem Cell Technologies, Vancouver, Canada). Este último é aprovado para diagnóstico pelo FDA (Food and Drug Administration) para uso na detecção, quantificação e monitoramento de células-tronco/progenitoras do sangue periférico, cordão umbilical e de medula óssea. Utilizando o kit Aldefluor ${ }^{\circledR}$, Ginestier et al. (2007) mostraram que células aldefluor+ de câncer de mama são altamente tumorigênicas e possuem propriedades de CSCs de auto-renovação e diferenciação. Dessa forma a ALDH1 é um marcador de células-tronco humanas normais e tumorais de mama, sendo considerado um marcador de pior prognóstico nestes tumores (GINESTIER et al., 2007). A atividade aumentada de ALDH foi encontrada também em populações de CSCs de mieloma múltiplo e leucemia mielóide aguda (MATSUI et al., 2004; PEARCE et al., 2005).

Foi observado que a população de células $\mathrm{ALDH}^{+}$estava aumentada em tumores de mama com alta expressão de HER2 (KORKAYA et al., 2008; MAGNIFICO et al., 2009; LI et al., 2008). Sendo que os níveis de ALDH se mostraram diretamente relacionados com alguns parâmetros clínicos, incluindo a maior expressão de HER2 (MORIMOTO et al., 2009). Desta maneira, a expressão de ALDH pode ser uma importante ferramenta de prognóstico para o câncer de mama, além de ser um marcador útil para o isolamento de CSCs.

\subsection{Linhagens celulares no estudo de CSCs}

Linhagens celulares representam populações policlonais de células que se adaptaram às condições em cultura, mas retiveram muitas de suas propriedades fenotípicas e genotípicas ao longo de diversas passagens. Alguns estudos demonstraram que linhagens celulares imortalizadas provenientes de camundongos e de humanos contêm populações celulares distintas, incluindo células com propriedades de células-tronco (CHRISTGEN et al., 2007; FILLMORE; KUPERWASSER, 2008; KONDO; SETOGUCHI; TAGA, 2004; SETOGUCHI et al., 2004). Desta forma, o uso de linhagens celulares de mama viabiliza o estudo destas CSCs, pois virtualmente não existe limite na obtenção destas células in vitro, ao contrário do uso de amostras derivadas de tumores primários. 
As CSCs de câncer de mama e as células progenitoras tumorais podem ser isoladas in vitro quando crescidas em suspensão, sob condições que não permitam sua diferenciação e evitem sua morte por apoptose. Estas células crescem em estruturas esferóides clonais em 3D, chamadas mamosferas, e tendem a expressar marcadores de células-tronco como OCT4 e BMI (KORKAYA et al., 2008).

\section{$1.5 O$ cultivo de células-tronco em condições não-aderentes}

O crescimento clonal em cultura não-aderente foi originalmente utilizado para testar a capacidade de auto-renovação em culturas de células neurais (REYNOLDS; WEISS, 1996). Culturas em suspensão favorecem a formação das, então chamadas, neurosferas que eram constituídas de 4-20\% de células-tronco. Essa técnica foi adotada para células de mama humanas por Dontu et al. em 2002 (DONTU et al., 2003).

A primeira descrição do cultivo de células-tronco e progenitoras de mama envolveu células não-tumorais derivadas de mamoplastias de redução que foram dissociadas mecânica e enzimaticamente gerando suspensões de células epiteliais mamárias únicas, quebrando desta forma, o dogma de que células epiteliais precisam estar ancoradas para crescer. As mamosferas são altamente enriquecidas em células indiferenciadas, como demonstrado pela capacidade das células-únicas de gerarem outras linhagens quando cultivadas sob condições apropriadas, na presença de alguns fatores de crescimento (DONTU et al., 2003). Enquanto que cerca de $8 \%$ das células isoladas de cultivo primário de tecido mamário são compostas por células progenitoras de multi-linhagens, este percentual sobe para $68 \%$ no cultivo de mamosferas primárias e chega a virtualmente $100 \%$ das células de segunda passagem ou passagens posteriores (DONTU et al., 2003). A frequência de formação das esferas permanece a mesma com as passagens, sugerindo que as células iniciadoras de esferas podem ser mesmo células-tronco. Além disso, a frequência de células capazes de produzir estruturas do complexo ducto-ácino em culturas de matrigel tridimensionais foi a mesma das células iniciadoras de esferas (DONTU et al., 2003).

Mamosferas também foram eficientemente produzidas a partir de células epiteliais de pacientes com DCIS. Estes tumores possuem uma pequena fração de células com capacidade de formar mamosferas, o que sugere a presença de CSCs. Das 29 amostras das lesões colocadas em cultura, 69\% foram capazes de formar mamosferas e estas estruturas foram passadas em cultura repetidamente, indicando sua capacidade de auto-renovação (FARNIE et al., 2007). Quando comparadas com células de tecido normal de mama, os DCIS possuem 
capacidade 3x maior de formar mamosferas (0,5\% versus 1,5\%) (FARNIE et al., 2007). Mamosferas derivadas de tumores também possuíam maior capacidade de auto-renovação, pois foram capazes de produzir novas gerações de células com razão de regeneração superior à das células normais (FARNIE et al., 2007). Tumores com graus histológicos mais avançados geraram mais mamosferas, sugerindo maior presença de células-tronco nos mesmos (FARNIE et al., 2007).

\section{6 miRNAs em células-tronco tumorais de tumores de mama}

As células-tronco são controladas por sinais extrínsecos, derivados principalmente de seu nicho regular (MESHORER et al., 2006; XI; XIE, 2005) e também por fatores intrínsecos como a expressão de alguns microRNAs (miRNAs ou miRs) (HOUBAVIY; MURRAY; SHARP, 2003; SUH et al., 2004), pequenos RNAs que interagem de maneira sequênciaespecífica com mRNAs ou outros RNAs-alvo) e são capazes de suprimi-los póstranscricionalmente. Independentemente do seu modo de ação os miRNAs afetam diretamente a quantidade de proteína produzida atuando de modo marcante na fisiologia celular. Já que um único miRNA pode interagir com centenas (600 a 800) de mRNAs, e hoje mais de 2 mil miRNAs humanos maduros já foram descritos (MIRBASE, 2012), é possível afirmar que os miRNAs talvez sejam a mais importante e mais ampla classe de reguladores negativos do genoma humano (BARTEL, 2004). Como alguns miRNAs regulam a diferenciação celular e podem funcionar como supressores tumorais ou como oncogenes (LU et al., 2005), a sua expressão desregulada é uma característica comum de tumores sólidos e hematopoiéticos (CALIN et al., 2002; RUVKUN, 2006).

Estudos demonstraram a importância e o potencial de miRNAs como biomarcadores em câncer de mama (revisto em ANDORFER et al., 2011). Alguns destes trabalhos mostraram a contribuição dos miRNAs na invasão e metástase (HUANG et al., 2008; IORIO et al., 2005; MA; TERUYA-FELDSTEIN; WEINBERG, 2007; VALASTYAN et al., 2009), na EMT (BRACKEN et al., 2009; GREGORY et al., 2008) e na manutenção das célulastronco tumorais (SHIMONO et al., 2009). Em estudo recente, Gong et al, (2011) mostraram que miR-21 encontra-se superexpresso em tumores de mama HER2+ que se tornam resistentes ao tratamento com tzb e que esta resistência ocorre pela inibição da expressão de PTEN por miR-21. A restauração da expressão de PTEN nas células resistentes a tzb restaura a sensibilidade destas células ao tratamento com esta droga. De maneira contrária, células sensíveis ao tratamento com tzb se tornam resistentes ao tratamento quando o miR-21 é 
superexpresso ectopicamente. A superexpressão de miR-21, e por consequência o bloqueio da expressão da proteína PTEN, também está associada à pior resposta ao tratamento com tzb em pacientes com câncer de mama (GONG et al., 2011). Este estudo mostra a importância do efeito de um desequilíbrio na expressão de miRNAs, que pode levar entre outras consequências, a uma pior resposta ao tratamento (GONG et al., 2011).

Alguns estudos mostraram que os miRs -221 e -222 estão altamente expressos em tumores de mama (ZHAO et al., 2008). Já foi descrito que estes miRNAs reprimem a expressão de p27 Kip1 p57 e do receptor de c-Kit, o que promove a proliferação e sobrevivência celular e inibe a sua diferenciação (FELLI et al., 2005; FELICETTI et al., 2008; GALARDI et al., 2007; LE SAGE et al., 2007; MEDINA et al., 2008; VISONE et al., 2007). Os miRs -221 e -222 regulam pós-transcricionalmente a expressão de ER e a deleção de ambos miRNAs nas células MDA-MB-468 levou à reconstituição da expressão de ER, tornando estas células sensíveis ao tratamento com tamoxifeno (ZHAO et al., 2008). De maneira oposta, quando os miRs -221 e -222 foram superexpressos nas células tumorais de mama MCF-7 e T47D, os níveis de expressão protéica de ER diminuíram e as células se tornaram resistentes ao tratamento com tamoxifeno (ZHAO et al., 2008). Apesar de os miRs 221 e 222 possuírem a mesma sequência de 8 nucleotídeos que determina o reconhecimento do alvo (seed-sequence) e ambos regularem a expressão de um grupo comum de genes (incluindo p27, p57, c-Kit e ER), o efeito da deleção de ambos miRNAs é mais significante do que a deleção de apenas um deles (ZHAO et al., 2008). Isso sugere a ocorrência de um efeito aditivo ou ainda que, quando atuando em conjunto, os miRs -221 e -222 possam exercer uma atividade regulatória em rede, que ainda não foi descrita (ZHAO et al., 2008).

Trabalhos anteriores descreveram que alguns miRNAs são diferentemente expressos em células-tronco, sugerindo um papel especializado na regulação dessas células (HOUBAVIY; MURRAY; SHARP, 2003; SUH et al., 2004). Seguindo este raciocínio, os miRNAs-221 e 222 podem ter um papel importante na biologia de CSCs de mama. Além disso, como os tumores HER2+ são enriquecidos em CSCs, é possível especular que os miRNAs -221 e -222 possam estar superexpressos e tenham um papel na agressividade e no prognóstico destes tumores.

Comumente, tumores HER2+ possuem amplificação do locus 17q21. Além de diversos genes de importância, nesta região genômica foram encontrados 5 miRNA-loops (miRs -4726, -4727, -296m, -4728 e -4734). Interessantemente, um destes miRNAs (miR4728) se localiza dentro de um dos introns de HER2 (PERSSON et al., 2011). Ambos os miRNAs maduros codificados por este miRNA, miR-4728-3p e miR-4728-5p foram 
encontrados associados com a proteína Argonauta-2, que é responsável pela clivagem dos mRNAs-alvo de miRNAs e siRNAs (PERSSON et al., 2011). A avaliação da expressão destes miRNAs em algumas linhagens celulares que possuem amplificação de HER2 (BT474, JIMT-1 e SKBR3) e duas linhagens-controle que não expressam HER2 (MCF-7 e MCF10A) mostrou que miR-4728-3p estava superexpresso apenas nas linhagens HER2+ (PERSSON et al., 2011). Este miRNA está localizado logo antes do quinto sítio de splicing do exon 24 de $H E R 2$, mostrando que seu processamento depende do splicing do próprio gene HER2. O transcrito de HER2 que contém o exon 24 também estava superexpresso nas mesmas linhagens HER2+ (PERSSON et al., 2011). Tumores derivados de pacientes com câncer de mama que superexpressam HER2 foram avaliados e mostraram que $66 \%$ dos 6 tumores avaliados superexpressavam ambos miR-4728-3p e o exon 24 de HER2 (PERSSON et al., 2011). Uma significativa expressão deste miRNA foi também observada em dados de nosso grupo, utilizando sequenciamento em larga-escala de 25 amostras de câncer de mama HER2+ (BRANCO et al., em preparação). Esses dados demonstram um papel complementar da expressão do gene HER2 em tumores de mama e sugerem a importância de miR-4728-3p na biologia destes tumores (PERSSON et al., 2011). Deste modo, já que tumores HER2+ mais agressivos possuem mais células-tronco tumorais e como o miR-4728-3p se encontra superexpresso em linhagens celulares que superexpressam HER2, é importante investigar o nível de expressão deste miRNA nas CSCs, assim como é importante a identificação dos genes-alvo regulados por miR-4728-3p.

Neste trabalho buscou-se contribuir para um melhor entendimento da biologia das células-tronco tumorais presentes em tumores de mama HER2+ tendo como foco o estudo do papel de expressões de alguns miRNAs nessas células. Os resultados previstos poderão contribuir futuramente com o desenvolvimento de novas estratégias terapêuticas, determinação de prognóstico e até mesmo com o desenvolvimento de novas drogas que atuem especificamente na subpopulação de células-tronco tumorais presentes em tumores HER2+. 


\section{CAPÍTULO I - EXPRESSÃO DE MIRNAS -221 E 222 EM CÉLULAS-TRONCO TUMORAIS}

\subsection{Objetivos}

- Avaliar o nível de expressão dos marcadores de pluripotência de células-tronco embrionárias OCT4, NANOG e SOX-2 na linhagem MCF-7 e em células $\mathrm{CD}_{4} 4^{+} / \mathrm{CD} 24^{-/ \text {baixa }}$ derivadas de pacientes com câncer de mama, em condições de cultivo aderente e em mamosferas;

- Avaliar o status dos marcadores de CSCs, CD44 e CD24, em células MFC-7, em condições de cultivo aderente e em mamosferas;

-Avaliar a expressão endógena dos miRNAs -221 e -222 na linhagem tumoral MCF-7 e em células derivadas de pacientes, cultivadas em condições aderentes e de mamosferas;

-Avaliar a influência da superexpressão dos miRNAs -221 e -222 na capacidade de formação de esferas (MFE) na linhagem celular MCF-7;

-Avaliar a influência da superexpressão dos miRNAs -221 e -222 na resistência ao tratamento com a droga paclitaxel.

\subsection{Materiais e métodos}

\subsubsection{Tumores primários de mama}

Amostras de células com fenótipo $\mathrm{CD}_{4} 4^{+} / \mathrm{CD} 24^{-/ \text {baixa }}$ derivadas de tumores primários de 3 pacientes com câncer de mama (pacientes 208, 308 e 708) de subtipo não especificado foram utilizadas em alguns dos experimentos deste estudo. Essas amostras, provenientes da Università degli Studi di Palermo, foram gentilmente cedidas ao Laboratório da Dr. Gerolama da Università degli Studi di Napoli Federico II. 


\subsubsection{Linhagem celular}

A linhagem tumoral de mama MCF-7, foi cultivada em meio Dulbecco's modied Eagle's médium (DMEM, Sigma-Aldrich, Saint Louis, MO, EUA), a $37^{\circ} \mathrm{C}$ em incubadora com uma atmosfera de 5\% (v/v) de dióxido de carbono e 95\% (v/v) de ar-ambiente.

\subsubsection{Cultura de mamosferas}

As células foram cultivadas em suspensão em meio Dulbecco's modied Eagle's medium containing/F12 - DMEM/F12 (Sigma) livre de soro, suplementado com B-27 (Life Technologies, Grand Island, NY, EUA), EGF (20 ng/mL) (BD-Becton, Dickinson and Company, Franklin Lakes, NJ, EUA), bFGF (10 ng/mL) (BD, EUA). As células diluídas a

$10^{4} \mathrm{cels} / \mathrm{mL}$ foram cultivadas em frascos de baixa adesão (Corning, Corning, NY, EUA) por 7-10 dias. Para serem propagadas, as mamosferas foram coletadas através de centrifugação e dissociadas em células únicas com o uso da solução 0,05\% tripsina-EDTA (Life Technologies) (DONTU et al., 2003).

\subsubsection{Análise dos marcadores CD44 e CD24 por citometria de fluxo}

As mamosferas cultivadas por 7 dias foram coletadas, dissociadas a células únicas e contadas. As células diluídas a $7 \times 10^{4}$ foram lavadas em solução salina fosfato (PBS) $1 \mathrm{x}$, ressuspendidas em $100 \mu \mathrm{L}$ de PBS 1x e incubadas com anticorpos primários diluídos antiCD44-PerCP-Cy-5.5 (BD) e anti-CD24-PE (BD). Como controle negativo foram utilizadas células incubadas com anticorpos anti-IgG mouse-PE para subtração do background e de células não marcadas. As porcentagens das populações CD44 e CD24 positivas foram analisadas separadamente através do instrumento de citometria de fluxo no FACSCalibur (BD) com a ajuda do programa CellQuest (BD).

\subsubsection{Extração de RNA, transcrição reversa e PCR quantitativo em tempo real}

RNAs totais (mRNAs e miRNAs) foram extraídos pelo método fenol-clorofórmio utilizando-se o reagente Trizol® (Life Technologies), segundo as instruções do fabricante. Posteriormente, foram quantificados no espectrofotômetro NanoDrop ${ }^{\circledR}$ ND-1000 (NanoDrop, 
Wilmington, DE, USA). RNAs totais foram tratados com 2U de Ambion ${ }^{\circledR}$ DNase (Life Technologies) em volume final de $50 \mu \mathrm{L}$, segundo as instruções do fabricante.

Para a transcrição reversa (RT), foram utilizados os kits miScript Reverse Transcription (Qiagen, Valencia, CA, EUA) para miRNAs e Superscript III First Strand (Life Technologies) para mRNAs. Para ambas RTs, $500 \mathrm{ng}$ de RNA total foram utilizados como molde. As amplificações por PCR quantitativo em tempo real (qRT-PCR) foram feitas utilizando iniciadores para amplificação dos transcritos dos genes SOX2, NANOG, OCT4 na presença de SYBR Green utilizando o gene da $\beta$-actina (ACTB) como controle endógeno (Quadro 1). As expressões dos miRNAs foram avaliadas por qRT-PCR utilizando o kit miScript SYBR Green PCR (Qiagen), que já contém os iniciadores (sequências não divulgadas pela empresa fabricante), segundo as instruções do kit e normalizadas utilizando o gene do small nuclear RNA (snRNA): RNU6B.

Quadro 1 - Sequências de iniciadores usados para a amplificação de mRNAs de interesse.

\begin{tabular}{|c|c|c|}
\hline & \multicolumn{2}{|c|}{ Iniciadores } \\
\hline & Senso 5'-3' & Antisenso 5'-3' \\
\hline ACTB & TGCGTGACATTAAGGAGAAG & GCTCGTAGCTCTTCTCCA \\
\hline NANOG & CAAAGGCAAACAACCCACTT & TCTGGAACCAGGTCTTCACC \\
\hline OCT4 & CGAAAGAGAAAGCGAACCAG & GCCGGTTACAGAACCACACT \\
\hline SOX2 & GCACATGAACGGCTGGAGCAACG & TGCTGCGAGTAGGACATGCTGTAGG \\
\hline
\end{tabular}

Para a determinação dos valores de expressão relativa dos mRNAs/miRNAs de interesse, foram feitos os seguintes cálculos:

$$
\begin{gathered}
\Delta \mathrm{Ct}=\mathrm{Ct}_{\text {gene alvo }}-\mathrm{Ct}_{\text {gene normalizador (para miRNA: RNU6B; para mRNA: GUSB) }} \\
\Delta \Delta \mathrm{Ct}=\Delta \mathrm{Ct}_{\text {amostra }}-\Delta \mathrm{Ct} \text { controle } \\
\text { Expressão relativa }=2^{-\Delta \Delta \mathrm{Ct}}
\end{gathered}
$$

Aos controles foi designado o valor 1 para o cálculo da expressão relativa das amostras. Assim, a expressão relativa da amostra foi obtida a partir da comparação dos níveis de expressão de cada um deles com o controle.

Os dados foram analisados através do programa GraphPad Prism versão 6.0 (GraphPad Software, Inc., La Jolla, CA, EUA). 


\subsubsection{Lentivetores baseados em HIV e superexpressão dos miRNAs}

Os cDNAs precursores de miR-221 e -222 foram amplificados a partir de cromossomo artificial de bactéria (BAC), clone humano, utilizando a enzima high fidelity AccuPrime Taq DNA polimerase (Life Technologies) (FELLI et al., 2005). Os miRNAs -221 e -222 foram, primeiramente, clonados no vetor $p C R$ 2.1-TOPO (Life Technologies). Posteriormente, foram inseridos abaixo do promotor CMV em um lentivetor de terceira geração $p R R L-C M V-P G K$ GFP-WPRE (Figura 2), chamado tween (BONCI et al., 2003; RICCI-VITIANI et al., 2004), para simultaneamente, transduzir o gene reporter GFP e o miRNA conforme descrito no trabalho de (FELLI et al., 2005).

\section{Lentivetor tween}

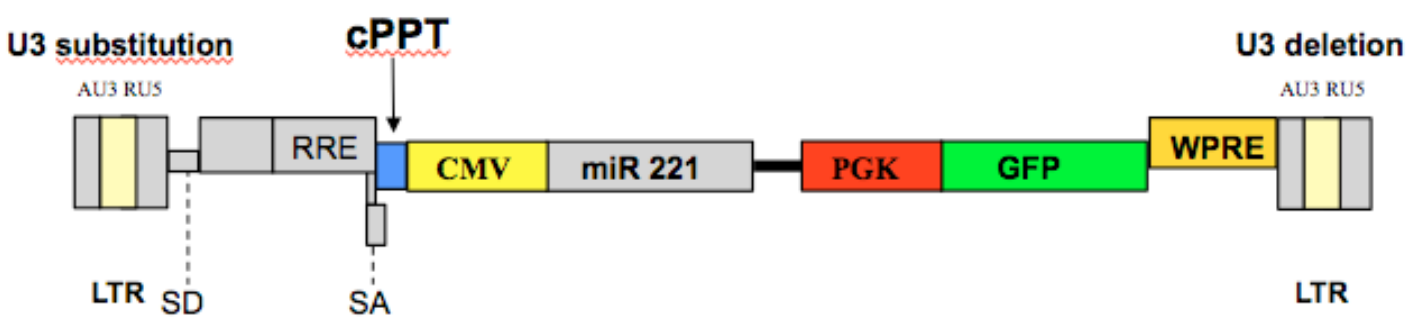

Figura 2 - Mapa linearizado do lentivetor tween com a sequência de miR-221.

Fonte: Felli et al. (2005).

Os iniciadores para amplificação foram: miR-221, 5'CCATTTGGGTGAAATCGTAT-3', 5'-GCATTTCTGACTGTTGGTTT-3', e miR 222, 5'TCATCATTCATAAAACCTTG-3'，5'-TACGTACATGGGAATATTGT-3'. (FELLI et al., 2005). Todas as sequências foram confirmadas por sequenciamento automatizado (Kimmel Cancer Institute, Thomas Jefferson University).

Todas as etapas de clonagem acima descritas, bem como a purificação dos plasmídeos, produção lentiviral, titulação e transdução nas células MCF-7 para superexpressão de precursores dos miRNAs -221, -222 foram realizadas pelo grupo da Dra Desirè Bonci na Università degli Studi di Roma segundo metodologia estabelecida por Felli et al. (2005).

\subsubsection{Eficiência de formação de mamosferas}

Para medir a eficiência da formação de mamosferas (MFE), em cada poço de uma placa de 96 poços (BD) foram plaqueadas $1 \times 10^{3}$ células tratadas com PolyHEMA (Sigma). Os experimentos foram realizados em triplicatas. O número de esferas com diâmetro $>60 \mu \mathrm{m}$ 
foi determinado por microscopia após 7 dias de cultivo. As aquisições de imagens e análises foram feitas com o software ImageJ (http://rsbweb.nih.gov/ij/). A MFE foi calculada dividindo o número de mamosferas formadas pelo número de células únicas plaqueadas. Os dados foram analisados através do programa GraphPad Prism versão 6.0 (GraphPad Software, Inc.).

\subsubsection{Ensaio de citotoxicidade}

Para analisar de uma possível correlação entre a expressão de miRNAs -221 e -222 em células-tronco tumorais de mama MCF-7 e a resistência destas células ao quimioterápico paclitaxel, foram feitos ensaios de citotoxicidade utilizando células MCF-7 após a trandução lentivitral com construtos de superexpressão dos miRNAs -221 e -222. A morte celular foi avaliada através do ensaio de MTT (3-(4,5-dimethylthiazol-2-yl)-2,5-dipheniltetrazolium bromide), conforme descrito abaixo:

As mamosferas foram desagregadas e as células foram plaqueadas em 6 replicatas para cada condição testada (miRNAs -221, -222 e construto controle tween) em microplacas de 96 poços. Após $24 \mathrm{~h}$ na presença da droga, as células foram incubadas por $20 \mathrm{~min}$ com o reagente MTT (20 $\mu \mathrm{L} /$ poço), do kit MTT-Cell Titer 96 Aqueous One Solution Cell Proliferation Assay (Promega, Madison, WI, EUA), para verificação das células metabolicamente ativas. As medidas de absorbâncias foram lidas no comprimento de onda de $490 \mathrm{~nm}$. Os resultados foram apresentados em porcentagem de células resistentes calculada a partir da divisão da média das absorbâncias das células tratadas pela média das absorvâncias das células não-tratadas. Os dados foram analisados através do programa GraphPad Prism versão 6.0 (GraphPad Software, Inc.).

O método descrito acima para avaliação de morte celular (ensaio de redução do MTT) representa uma indicação indireta de apoptose, uma vez que fornece informações apenas sobre a viabilidade celular e citotoxicidade, sendo baseado principalmente, mas não exclusivamente, na atividade funcional de mitocôndrias. 


\subsection{Resultados e discussão}

\subsubsection{Formação de mamosferas}

Células derivadas de tumores primários de 3 pacientes com tumores primários de mama (pacientes 208, 308 e 708), e células da linhagem MCF-7 foram crescidas em condições de formação de mamosferas (em suspensão) (Figura 3A) e em condição aderente (Figura 3B). A formação de mamosferas foi bem sucedida, como exemplificado para as células MCF-7 (Figura 3B).

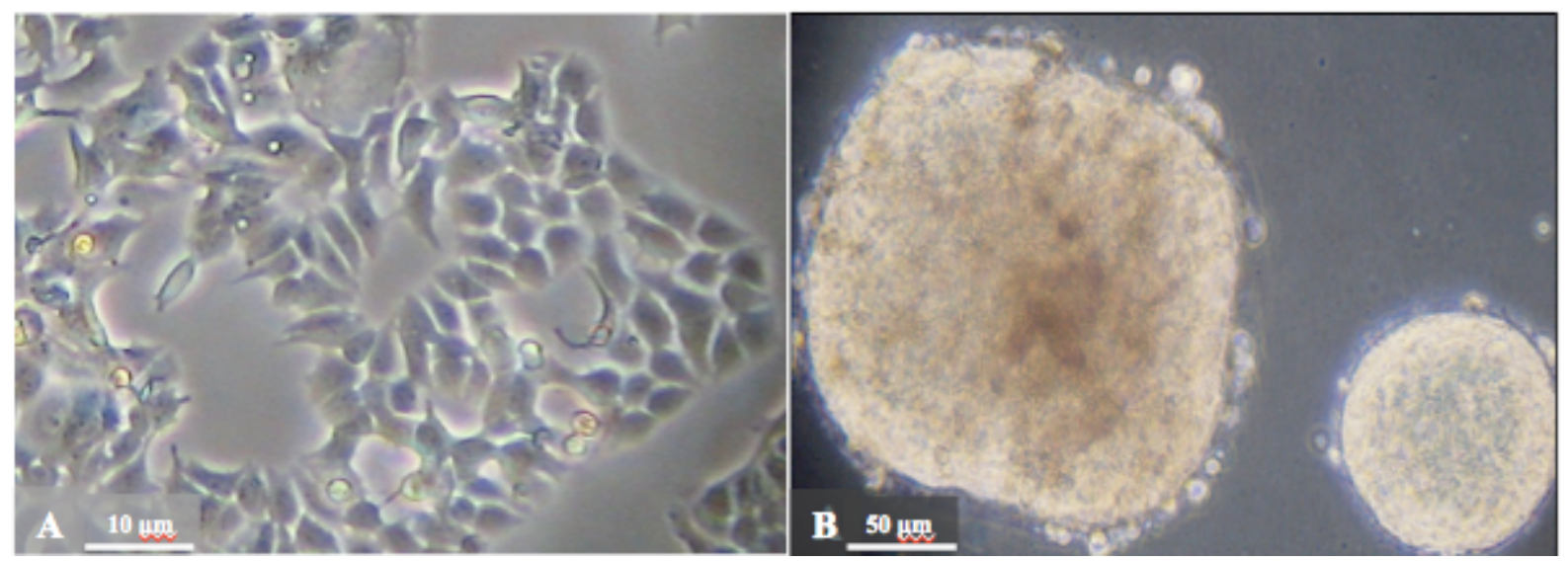

Figura 3 - Culturas da linhagem celular MCF-7 em monocamada aderente e em condição de formação de mamosferas. (A) células crescidas em monocamada aderente e (B) em condição de formação de mamosferas.

Em relação às características morfológicas das mamosferas formadas a partir da linhagem MCF-7, foi observado que o tamanho das mamosferas variou de 40-100 $\mu \mathrm{m}$. As esferas eram geralmente regulares, com poucas exceções, e possuíam aparência firme com células bem aderidas entre si.

Em relação às características morfológicas das mamosferas formadas a partir de culturas primárias de tumores provenientes das 3 pacientes citadas acima, foi observado que, diferentemente de células MCF-7, seu tamanho variou de 25-70 $\mu \mathrm{m}$, as esferas possuíam formato na sua grande maioria irregular e possuíam aparência de células menos aderidas entre si (figuras não mostradas).

Neste trabalho, as mamosferas foram cultivadas por 7 dias a fim de verificar: a expressão de marcadores de pluripotência de células-tronco embrionárias, a expressão de marcadores de CSCs de mama, CD44 e CD24, e analisar o perfil de expressão dos miRNAs 221 e -222. 


\subsubsection{Avaliação da expressão de marcadores de pluripotência}

Para a confirmação do enriquecimento de células-tronco nas culturas de mamosferas provenientes das 3 pacientes e de células MCF-7, foram avaliados três marcadores de pluripotência de células-tronco embrionárias SOX2, OCT4 e NANOG (YU et al., 2007) como mostrado na Figura 4 (A, B e C).

A

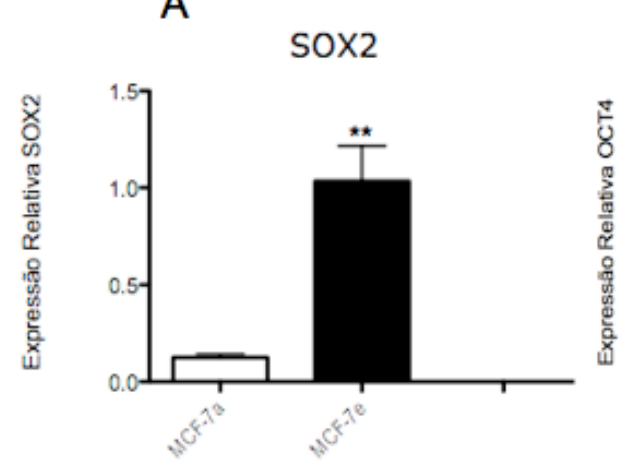

B

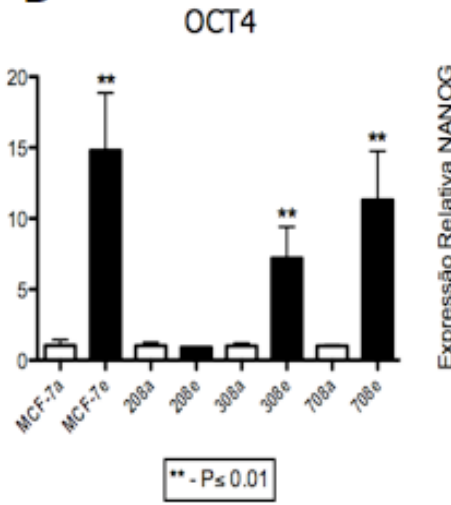

C

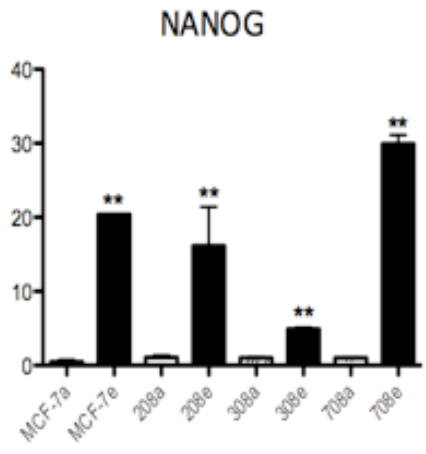

Figura 4 - Avaliação da expressão gênica de marcadores de pluripotência de células-tronco embrionárias SOX2, OCT4 e NANOG em linhagem MCF-7 e em células derivadas de tumores primários de três pacientes $(208,308$ e 708). (A) Expressão de $S O X 2 \mathrm{em}$ células aderentes (a) e em mamosferas (e) derivadas da linhagem celular MCF-7. Expressão de OCT4 (B) e NANOG (C) em células aderentes (a) e mamosferas (e) da linhagem celular MCF-7 e células tumorais provenientes das pacientes 208, 308 e 708. As barras indicam as médias de expressão relativa, com os respectivos desvio-padrão observados nas médias de expressão dos referidos genes (triplicatas). Asteriscos $(* *)$ indicam diferença estatisticamente significativa entre condição aderente e de esferas, Teste-t de Student. $(\mathrm{P}<0,01)$.

A partir dos resultados acima, observou-se que $S O X 2$ (Figura 4) estava aumentado em 10x nas mamosferas quando comparado com células aderentes MCF-7. Conforme mostrado na Figura 4B, OCT4 se mostrou mais expresso em cultura de mamosferas em relação à cultura de células aderentes, tanto em MCF-7 (aproximadamente 15x), quanto em células tumorais provenientes de 2 dos 3 pacientes (308: 7x e 708: 12x).

Estudos recentes demonstram que os marcadores de células-tronco SOX2, OCT4 e NANOG se encontram altamente expressos na linhagem MCF-7 em culturas de mamosferas quando comparados com culturas em monocamada (DEBEB et al., 2010; OAK et al., 2012). Resultados de imunohistoquímica em neoplasia intraepitelial pancreática sugerem que SOX2 está envolvido em eventos tardios da carcinogênese deste tumor, tais como invasão e 
metástase (SANADA et al., 2006). Porém, foi observado em tumores de mama que SOX2 também se encontra expresso em estágios precoces da doença (LEIS et al., 2012). Conforme este gráfico, observou-se maior expressão de $S O X 2$ em MCF-7 em culturas de mamosferas em comparação com culturas em monocamada. Infelizmente não foi possível avaliar a expressão de $S O X 2$ nas amostras de pacientes, devido à limitada quantidade de tecido tumoral disponível (Figura 4A).

A expressão de SOX2 tem sido observada em $43 \%$ dos carcinomas de mama de subtipo basal e parece estar correlacionada com a imunoreatividade de CK5/6, EGFR, e vimentina - importantes marcadores no processo de transição epitélio-mesênquima, sugerindo que o $S O X 2$ possa exercer algum papel no fenótipo menos diferenciado desses tumores (RODRIGUEZ-PINILLA et al., 2007).

Conforme mostrado na Figura 4B, OCT4 se mostrou mais expresso em cultura de mamosferas em relação à cultura de células aderentes tanto em MCF-7, quanto em células tumorais provenientes de 2 dos 3 pacientes (308 e 708). O gene OCT4, é um membro da família de fatores de transcrição POU, expresso em células-tronco embrionárias e célulastronco adultas (NICHOLS et al., 1998, NIWA et al., 2000; BABAIE et al., 2007). Recentemente, foi demonstrado que além da proteína codificada por OCT4 estar envolvida na manutenção da pluripotencialidade de células-tronco embrionárias, ela também está relacionada ao potencial de proliferação. A via de sinalização OCT4/Tcl1/Akt1 está envolvida na proliferação dessas células inibindo a apoptose (MATOBA et al., 2006). A expressão de OCT4 também foi detectada em células de tumores germinativos (COOLS et al., 2006) e em alguns tumores de células somáticas, como o hepatoma (COOLS et al., 2006; SHIN et al., 2006), câncer de mama (EZEH et al., 2005; TAI et al., 2005), câncer de bexiga (ATLASI et al., 2007; GU et al., 2007) entre outros. Apesar de muitas células tumorais expressarem OCT4, pouco se sabe sobre sua função no câncer. O knockdown de OCT4 mediado por RNA de interferência (RNAi) em linhagens tumorais, tais como em MCF-7, e mais recentemente em linhagens de câncer de ovário pouco diferenciado, levou a uma redução da sobrevivência celular (PENG; MAIHLE; HUANG, 2010) e à inibição do seu potencial tumorigênico (HU et al., 2008). Essas observações demonstram um importante papel de OCT4 na manutenção da auto-renovação aberrante de células tumorais e, possivelmente na formação tumoral (BELTRAN et al., 2011).

Conforme observado na Figura 4B, nem todos os pacientes apresentaram níveis elevados de OCT4 nas mamosferas, em relação às células aderentes. O paciente 208 apresentou níveis de OCT4 semelhantes em ambas as condições de cultivo celular. Estudos 
recentes demonstram que existe uma variação no nível de expressão de OCT4 nos diferentes subtipos de tumores de mama: tumores de mama pertencentes ao subtipo basal e ao subtipo com baixos níveis de expressão de claudina, molécula envolvida na adesão celular, são particularmente enriquecidos de marcadores de CSCs (PRAT et al., 2010; HONETH et al., 2008). Como não foi possível a obtenção de maiores dados referentes às pacientes, uma discussão mais aprofundada deste resultado não pôde ser realizada.

\subsubsection{Avaliação dos marcadores de CSCs de mama}

A porcentagem das populações celulares que apresentavam os marcadores de CSCs CD44 e CD24 por citometria de fluxo, em células derivadas de mamosferas e células aderentes da linhagem MCF-7, é apresentada na Tabela 1 abaixo:

Tabela 1 - Porcentagem de células $\mathrm{CD}_{4} 4^{+}$e $\mathrm{CD} 24^{-/ b a i x a}$ em células aderentes e derivadas de mamosferas da linhagem MCF-7. Controles negativos: Células não tratadas com anticorpos e células tratadas com anticorpo inespecífico IgG-PE.

\begin{tabular}{lcc}
\hline & $\begin{array}{c}\text { Células } \\
\text { aderentes (\%) }\end{array}$ & $\begin{array}{c}\text { Mamosferas } \\
(\%)\end{array}$ \\
\hline Controle negativo (células não-tratadas) & 0 & 0 \\
Controle negativo (IgG-PE não específico) & 0 & 0 \\
Anti CD44 - PerCP - Cy5.5 & 12 & 35 \\
Anti CD24 - PE & 56 & 9 \\
\hline
\end{tabular}

Conforme esperado, foi observado um maior percentual de células $\mathrm{CD} 44^{+}$nas culturas de mamosferas, quando comparadas às células crescidas em condição de aderência $(35 \%$ versus $12 \%$, respectivamente). Do mesmo modo, a população de células negativas para o marcador CD24 foi de apenas 9\% nas mamosferas, contra 56\% nas células aderentes.

Apesar dos marcadores terem sido analisados separadamente, esses resultados podem indicar um enriquecimento de CSCs nas culturas de mamosferas de acordo com alguns trabalhos como o de Al-Hajj et al. (2003), quefoi o primeiro a demonstrar um enriquecimento do fenótipo $\mathrm{CD} 44^{+} / \mathrm{CD} 24^{-/ \text {baixa }}$ em CSCs de mama, as quais eram altamente tumorigênicas. Essas células descritas por Al-Hajj et al. (2003) possuíam características de células com perfil basal/mesenquimal que haviam passado pela EMT.

Guttilla et al. (2012) demonstraram que culturas prolongadas de mamosferas da linhagem MCF-7 enriquecem para uma população estável de células mesenquimais $\mathrm{CD} 44^{+} / \mathrm{CD} 24^{-/ \text {baixa }}$ através do processo EMT. Da mesma forma observado por Mani et al. 
(2008), que demonstraram o enriquecimento de células com fenótipo CD44 $4^{+} \mathrm{CD} 24^{-/ \text {baixa }}$ após a indução de EMT em células tumorais de mama epiteliais humanas.

Infelizmente não foi possível a realização dessa análise com material proveniente de paciente, devido à limitada quantidade de tecido tumoral disponível.

\subsubsection{Avaliação da expressão endógena dos miRNAs -221 e -222}

A expressão endógena de miR-221 e -222 foi avaliada em células MCF-7 aderentes e em suas mamosferas, bem como em células aderentes e mamosferas derivadas das três pacientes (208, 308 e 708). Para ambos miRNAs a expressão se mostrou aumentada nas mamosferas para a maioria dos casos (Figura 5).

$\mathbf{A}$

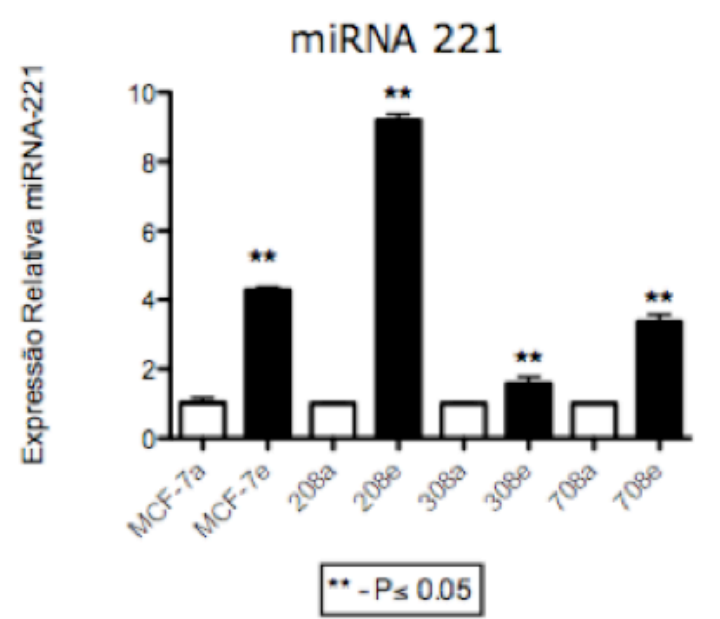

B

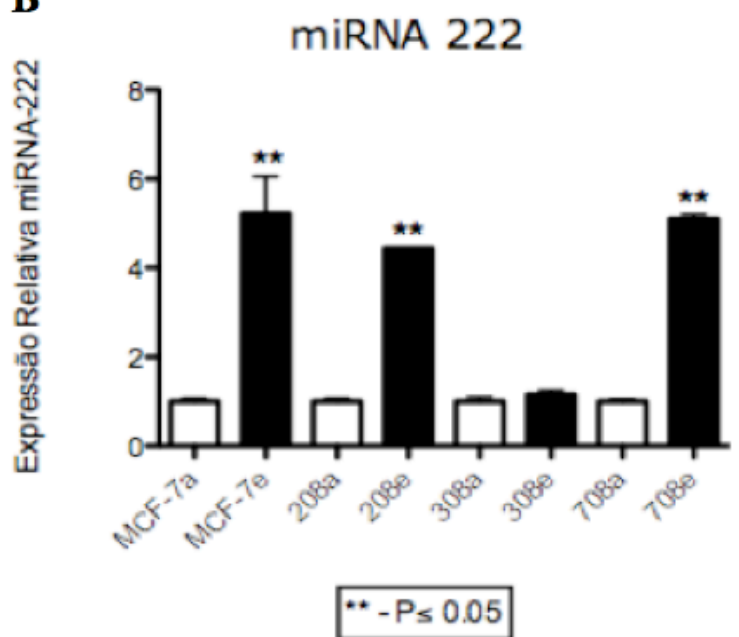

Figura 5 - Avaliação da expressão endógena de miR-221 e -222 em células MCF-7 ou células derivadas de tumores primários de três pacientes (208, 308 e 708). (A) Expressão relativa do miRNA-221 em células aderentes (a) e em mamosferas (b) derivadas da linhagem MCF-7 e provenientes de tumor de pacientes. (B) Expressão relativa do miRNA-222 em células aderentes (a) e em mamosferas (b) derivadas da linhagem MCF-7 e provenientes de tumor de pacientes. As barras indicam a média da expressão dos referidos genes (triplicatas), com respectivos desvios-padrão, enquanto que os asteriscos (**) indicam significado estatístico Teste-t de Student $(\mathrm{P}<0,05)$.

Em relação à expressão de miR-221 e -222 em mamosferas de MCF-7, observou-se um aumento de $4 x$ e $5 x$, respectivamente, quando comparada com células aderentes. Em relação às pacientes 208, 308 e 408, as expressões do miRNA-221 estava aumentada nas mamosferas em 9x, 1,7x e 3x, respectivamente, e em relação ao miRNA-222, a expressão estava aumentada em 4,5x, 1,3x e 5x, respectivamente. 
Curiosamente, mamosferas derivadas do tumor da paciente 308, além de apresentarem expressão de marcadores de pluripotência baixos, também apresentaram baixa expressão de ambos os miRNAs. O fato de não haver informações sobre o subtipo do tumor de mama dessa paciente pode levar a algumas suposições.

A superexpressão de miR-221 e -222 está relacionada com a agressividade tumoral e, geralmente, estes miRNAs estão superexpressos em tumores agressivos (FELICETTI et al., 2008; GALARDI et al., 2007; PINEAU et al., 2010).

Tanto o miRNA-221 quanto o miRNA-222 têm um papel oncogênico, por sua capacidade de reprimir a produção de proteínas inibidoras do ciclo celular p27/Kip1 e p57, o que facilita a proliferação celular e a auto-renovação (MILLER et al., 2008). A superexpressão destes miRNAs em tumores ER-negativos foi reportada anteriormente (ZHAO et al., 2008), sugerindo seu papel no status de ER em tumores de mama agressivos. Estes mesmos autores (ZHAO et al., 2008) mostraram em um trabalho posterior que os miRNAs -221 e -222 agem diretamente no ER e a sua superexpressão contribui para a progressão do fenótipo mais agressivo dos tumores basais ER-negativos.

Culturas de mamosferas da linhagem MCF-7 apresentaram um aumento relevante de fatores de transcrição associados à EMT e marcadores mesenquimais, além disso mostraram diminuição de ER e de marcadores epiteliais (GUTTILLA et al., 2012). A expressão dos miRNAs -221 e -222 foi investigada nestas células e foi demonstrado que ela estava aumentada (GUTTILLA et al., 2012). Estas células também produziram tumores maiores quando injetadas em camundongos imunodeficientes com ou sem suplementação de estrógeno (GUTTILLA et al., 2012).

Stinson et al. (2011) demonstraram que os miRNAs -221 e -222 promovem a EMT em tumores mama basal-like por impedir a transcrição do fator de transcrição repressor TRPS1 (síndrome trico-rino-falangeal, tipo 1), o qual inibe a EMT pela diminuição de ZEB2 (zinc finger E-box-binding homeobox2) expression.

De acordo com os trabalhos citados acima e com os resultados apresentados neste trabalho (Figura 5), a expressão aumentada de miR-221 e -222 em mamosferas indica que essas moléculas possivelmente estão envolvidas em vias regulatórias de CSC de mama. 


\subsubsection{Avaliação da superexpressão dos miRNAs -221 e -222 em MCF-7}

A eficiência de infecção dos construtos lentivirais para a superexpressão de miR-221 e -222, e tween em células MCF-7 foi analisada por citometria de fluxo se mostrou superior a $86 \%$ (média de 90,3\% das células infectadas - Tabela 2 ).

Tabela 2 - Análise da eficiência de infecção com vetores lentivirais para a superexpressão dos miRNAs -221 e -222 em células MCF-7 aderentes. Controles: MCF-7 wild-type (sem infecção) e MCF-7 tween (controle).

\begin{tabular}{lc}
\hline \multicolumn{1}{c}{ Células } & \% Células GFP+ \\
\hline MCF-7 wild-type & 1 \\
MCF-7-tween & 86 \\
MCF-7 miR-221 & 90 \\
MCF-7 miR-222 & 95 \\
\hline
\end{tabular}

A seguir, foi avaliada se a transdução em células MCF-7 com os construtos lentivirais dos miRNAs -221 e -222 de fato ocorreu um aumento da expressão destes miRNAs como era de se esperar (Figura 6).

miR-221 e miR-222

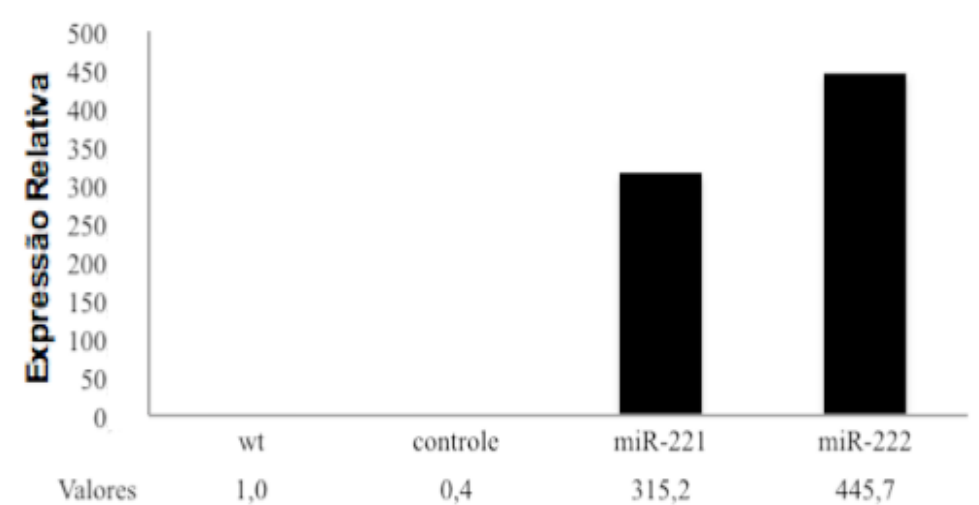

Figura 6 - Expressão relativa de miR-221 e -222 em células MCF-7 derivadas de culturas de mamosferas transduzidas com construtos para a superexpressão de miR-221 e -222. wt (wild-type), controle (tween), miR-221 e miR-222 (células transduzidas com construtos para a superexpressão de miR-221 e -222 , respectivamente). Os valores de expressão relativa foram calculados em relação às células wt.

Conforme mostrado na Figura 6 logo acima, a expressão de ambos miRNAs foi significativamente aumentada após a transdução. Alterações significativas não foram observadas após a transdução com o construto controle. 
2.3.6 Eficiência de formação de mamosferas após superexpressão de miR-221 e -222 em células MCF-7

$\mathrm{Na}$ etapa seguinte, foram avaliados os efeitos da superexpressão de miR-221 e -222 sobre a eficiência de formação de mamosferas (MFE) (Figura 7).

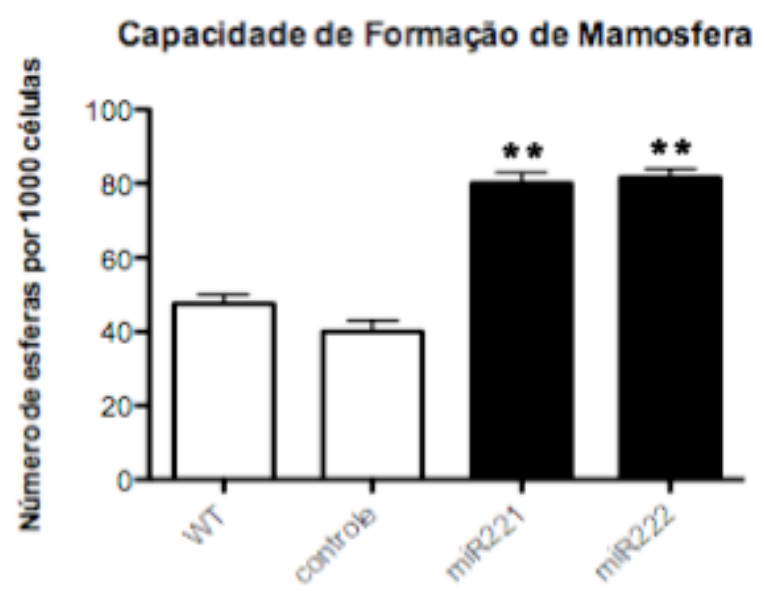

Figura 7 - Avaliação da eficiência de formação de mamosferas na linhagem celular MCF-7 transduzida com construtos para a superexpressão de miR-221 e -222. (WT) MCF-7 wild-type, controle (tween). As barras indicam a média da expressão dos referidos genes (triplicatas), com respectivos desvios-padrão, enquanto que os asteriscos $(* *)$ indicam significado estatístico Teste-t de Student $(\mathrm{P}<0,01)$.

Os ensaios de formação de mamosferas mostraram que células que superexpressavam os miRNAs -221 e -222 testados foram cerca de 2x mais eficientes na formação de esferas quando comparados aos controles. Estes dados sugerem que miR-221 e -222 possam estar envolvidos no processo de auto-renovação das CSC de mama.

Existem muitos trabalhos descrevendo a importância dos papéis dos miRNAs em vários tipos de tumores, bem como, na diferenciação e auto-renovação de células-tronco. Porém, ainda existem poucos estudos mostrando a importância dos miRNAs em CSCs. Yu et al. (2007) mostraram que o miRNA let-7 estava reduzido em CSCs de mama e aumentado em células diferenciadas. Neste mesmo trabalho, a superexpressão de let-7 mediada por lentivetores reduziu a proliferação, a formação de mamosferas e a proporção de células indiferenciadas in vitro, enquanto a auto-renovação in-vitro foi aumentada através do oligonucleotídeos inibidores de let-7.

O trabalho de Stinson et al. (2011), que demonstrou pela primeira vez a relação direta dos miRNAs -221 e -222 em vias de EMT, apontam para a significância do potencial desses miRNAs na regulação de funções biológicas das CSCs em mama. Portanto, de acordo 
com os trabalhos citados acima e com os resultados apresentados neste trabalho (Figura 7) sugere-se que miR-221 e -222 possam estar envolvidos em vias regulatórias de autorenovação e manutenção das CSC de mama.

\subsubsection{Resistência à morte celular na presença de paclitaxel após superexpressão dos miRNAs -221 e -222 em células MCF-7}

Ensaios de citotoxicidade (MTT) foram realizados a fim de investigar se a superexpressão de miR-221 e -222, além de afetar a formação de mamosferas, também teriam alguma influência na resistência ao paclitaxel em células da linhagem MCF-7 derivadas de culturas de mamosferas.

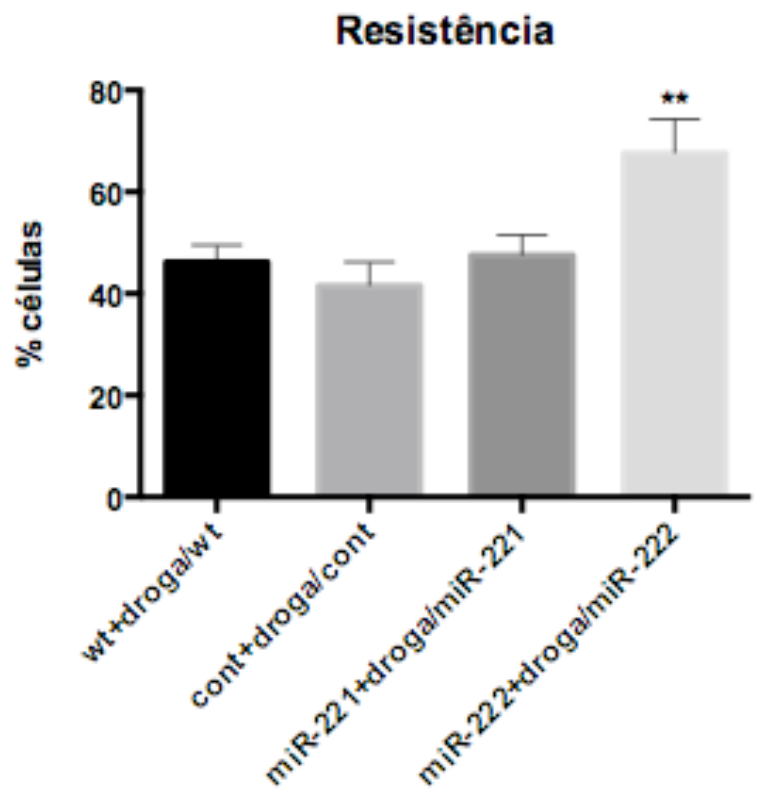

Figura 8 - Avaliação da resistência à apoptose em cultura de mamosferas de células MCF-7 superexpressando miR-221 ou -222 e tratadas com paclitaxel. Razão entre as médias das 6 replicatas de células tratadas com paclitaxel e as médias das 6 replicatas das mesmas células não tratadas. wt (wild-type), cont (tween), miR-221 e miR-222 (células que superexpressam miRNAs -221 e -222 , respectivamente). Asteriscos (**) indicam significado estatístico Teste-t de Student. $(\mathrm{p}<0,01)$.

Conforme mostrado acima (Figura 8) células derivadas de mamosferas que superexpressavam miR-222, se mostraram bem mais resistentes após o tratamento com tratadas com paclitaxel (aproximadamente 70\% das células se mostraram resistentes), quando comparadas com os controles. Nenhum efeito relativo à resistência ao paclitaxel foi observado nas células que superexpressavam miR-221 (Figura 8). 
Esse resultado sugere que o miRNA-222 pode conferir resistência à quimioterapia com paclitaxel em CSCs de mama.

A resistência de CSCs é demonstrada por váriaos trabalhos. Singh e Settleman (2010) descreveram que a resistência à citotoxicidade quimioterápica pode estar associada à EMT e às CSCs. A resistência aos quimioterápicos docetaxel e altas doses de tamoxifen foi maior em mamosferas do que em células aderentes da linhagem MCF-7 (GUTTILLA et al., 2012).

Foi verificado que os miRNAs -221 e -222 estavam aumentados em células tumorais de mama resistentes ao paclitaxel (ZHOU et al., 2010). Porém, ainda não foram realizados estudos envolvendo esses miRNAs na resistência de CSCs ao tratamento com paclitaxel.

O fato da resistência ao paclitaxel não ser observado em CSCs que superexpressam o miRNA-221 pode sugerir que estes miRNAs exercem diferentes papéis entre si na regulação das CSCs na linhagem MCF-7.

Apesar dos miRNAs -221 e -222 terem a mesma seed-sequence eles possuem apenas três nucleotídeos adicionais em comum no restante das sequências na direção 3'. Estudos anteriores mostraram que resíduos downstream à seed-sequence, particularmente os nucleotídeos 13-16, que por sua vez são diferentes entre os miRNAs -221 e -222, possuem um papel significante na atividade de miRNAs (BAEK et al., 2008). Esta diferença é refletida nos papéis distintos que esses miRNAs podem exercer, o que é demonstrado por alguns estudos envolvendo a superexpressão dessas moléculas (NASSIRPOUR et al., 2013; SHAH; CALLIN, 2011).

Os experimentos realizados neste primeiro capítulo da tese foram de fundamental importância para o aprendizado de técnicas que futuramente seriam utilizadas na continuação desse estudo no Brasil (capítulo II deste trabalho). 


\section{CAPÍTULO II - PAPEL DOS MIRNAS -221, -222 E -4728 EM CÉLULAS-TRONCO HER2+}

\subsection{Objetivos}

- Avaliar a eficiência de formação de mamosferas derivadas em linhagens celulares tumorais de mama HER2+;

- Avaliar a expressão endógena dos genes SOX2, OCT4, NANOG, LIN28, KLF4 e HER2 e dos miRNAs -221, -222 e -4728-3p nas linhagens de mama cultivadas em condição aderente e de mamosferas;

- Quantificar a fração das populações celulares $\mathrm{CD} 44^{+} / \mathrm{CD} 24^{-/ \text {baixa }}$ e $\mathrm{ALDH}^{+}$nas linhagens celulares de mama HER2+, cultivadas em condição aderente e de mamosferas;

- Avaliar a expressão de ALDH nas linhagens celulares e separá-las após a indução da superexpressão estável dos miRNAs -221, -222 e -4728-3p;

- Avaliar a influência da superexpressão de miR-221, -222 e 4728-3p em subpopulações celulares $\mathrm{ALDH}^{+}$na proliferação dessas células.

\subsection{Materiais e métodos}

\subsubsection{Cultura de linhagens celulares}

As linhagens celulares de câncer de mama utilizadas nesse trabalho foram adquiridas diretamente da American Type Culture Collection (ATCC, Rockville, MD, EUA) e são descritas abaixo:

- BT-474: Linhagem derivada de um adenocarcinoma ductal invasivo de mama de subtipo luminal B (receptor de estrógeno (ER) positivo e receptor de progesterona (PR) negativo) com alta expressão endógena de HER2. Cultivada em Dulbecco's Modified Eagle Medium nutrient mixture F-12 (DMEM/F12 - Life Technologies) com 2,5 mM L-Glutamina, $10 \%(\mathrm{v} / \mathrm{v})$ de soro fetal bovino (FBS) e 1\% (v/v) antibiótico-antimicótico (100 unidades/mL de penicilina, $100 \mu \mathrm{g} / \mathrm{mL}$ de estreptomicina e $0,25 \mu \mathrm{g} / \mathrm{mL}$ de anfotericina B) (Life Technologies). 
- SKBR3: Linhagem derivada de adenocarcinoma ductal invasivo de mama que expressa altos níveis de HER2 (KOYAMA et al., 2007) e não expressa os receptores hormonais ER e PR. Cultivada nas mesmas condições descritas para a linhagem celular BT474.

- MCF-7: Linhagem derivada de adenocarcinoma ductal invasivo de mama de subtipo luminal B (ER+ e PR-). Apresenta baixa expressão de HER2 (SIDDIQA et al., 2008) e foi usada como controle negativo em relação às linhagens acima descritas. Cultivadas em meio DMEM (Life Technologies) 10\% (v/v) FBS e 1\% (v/v) antibiótico-antimicótico (Life Technologies)

- 293T/17: Clone de linhagem epitelial embrionária de rim humano. Expressa constitutivamente o antígeno $\mathrm{T}$ grande do vírus símio 40 (SV40) e este clone (17) foi selecionado especificamente por sua alta capacidade de ser transfectado. Cultivadas nas mesmas condições que células MCF-7.

Todas as linhagens foram cultivadas a $37^{\circ} \mathrm{C}$ em incubadora com $5 \%(v / v)$ de dióxido de carbono e $95 \%(\mathrm{v} / \mathrm{v})$ de ar.

\subsubsection{Cultura de mamosferas}

As linhagens de câncer de mama foram cultivadas em suspensão, em meio DMEM/F12 (Life Technologies), sem soro, suplementado com: B-27 (Life Technologies), fator de crescimento epidermal (EGF - $20 \mathrm{ng} / \mathrm{mL}$ - Sigma-Aldrich), fator de crescimento de fibroblastos básico (bFGF - $10 \mathrm{ng} / \mathrm{mL}$ - Sigma-Aldrich, insulina (5 $\mu \mathrm{g} / \mathrm{mL}$ - Novo Nordisk, Montes Claros, MG, Brasil) e hidrocortisona (0,5 $\mu \mathrm{g}$ - Pouso Alegre, MG, Brasil). As células foram cultivadas em frascos de baixa adesão (Corning, Corning, NY, EUA) na densidade de $10^{4}$ cels $/ \mathrm{mL}$. As culturas celulares foram incubadas por $7,14,21$ e 28 dias $\left(1^{\mathrm{a}}, 2^{\mathrm{a}}, 3^{\mathrm{a}}\right.$ e $4^{\mathrm{a}}$ gerações, respectivamente). A cada 7 dias as esferas foram desagregadas a células únicas com ajuda do reagente Accumax (Stem Cell Technologies, Vancouver, BC, Canadá) em uma incubação de 10 min a $37^{\circ} \mathrm{C}$ e re-cultivadas para a próxima geração.

\subsubsection{Citometria de fluxo}

Para a separação de células transduzidas com contrutos para a expressão da proteína RFP (Red Fluorescence Protein), foi utilizado o aparelho FACSAria III (BD-Becton, 
Dickinson and Company) do CEFAP (Centro de Facilidades para Pesquisas, ICB, USP, São Paulo, SP), como prestação de serviços. Aproximadamente $10^{7}$ células de cada população transduzida foram utilizadas por experimento. Essas células foram previamente filtradas em filtros de $70 \mu \mathrm{M}(\mathrm{BD})$ e mantidas a $4^{\circ} \mathrm{C}$ até o momento de sua leitura no citômetro. A RFP intracelular foi excitada com o laser vermelho e detectada no fotomultiplicador do APC com filtro $585 / 42$.

Para a separação por citometria de fluxo das células $\mathrm{ALDH}^{+}, 5 \times 10^{5}-10^{6}$ células foram tratadas com o reagente Aldefluor ${ }^{\mathrm{TM}}$ (Stem Cell Technologies), conforme as instruções do fabricante. As células separadas foram coletadas em tubo Falcon contendo meio de cultura completo (antibiótico $1 \%$ e soro $10 \%$ ) e mantidas a $4^{\circ} \mathrm{C}$ até o seu plaqueamento em placas de 24 ou 96 poços, dependendo do número total de células separadas obtidas em cada condição.

Para a identificação de células humanas que expressam altos níveis da enzima ALDH, utilizamos o reagent Aldefluor ${ }^{\mathrm{TM}}$. Este reagente é constituído de BODIPYTM_ aminoacetoaldeído (BAAA), um substrato fluorescente de ALDH que não é tóxico e que se difunde livremente em células viáveis e intactas. Na presença de ALDH, BAAA é convertido em BODIPYTM-aminoacate (BAA) que é retido dentro das células. A quantidade de produto fluorescente é proporcional à atividade de ALDH nas células, que é medido através de citometria de fluxo. O efluxo ativo da reação é inibido pelo tampão Aldefluor ${ }^{\mathrm{TM}}$ Assay Buffer (Stem Cell Technologies), que contém inibidores de efluxo que bloqueiam a atividade dos transportadores $\mathrm{ABC}$ expressos na maioria das células. Células viáveis fluorescentes chamdas ALDH-bright (ALDHbr), foram lidas no canal do fluoróforo FITC-FL1. Um inibidor específico de ALDH, dietilaminobenzaldeído (DEAB), é usado nos controles para eliminar o ruído de fluorescência. Assim, os controles foram as mesmas amostras tratadas com o kit, porém na presença do inibidor DEAB. As células wild-type (wt) foram separadas em 2 populações: $\mathrm{ALDH}^{+}$e $\mathrm{ALDH}^{-}$, já nas populações transduzidas apenas as subpopulações $\mathrm{ALDH}^{+}$foram separadas.

Para a análise das porcentagens de populações celulares $\mathrm{CD}_{4} 4^{+} / \mathrm{CD} 24^{+}, \mathrm{CD} 44^{+} / \mathrm{CD} 24^{-}$ , $\mathrm{CD}_{4} 4^{-} / \mathrm{CD} 24^{+}$e $\mathrm{CD}_{4} 4^{-} / \mathrm{CD} 24^{-}$, as células foram previamente tratadas com tripsina $0,25 \%$ (v/v) - EDTA 0,913 mM (Life Technologies). Já as mamosferas foram dissociadas a células únicas que foram então lavadas com solução salina fosfato sem cálcio e magnésio (PBSA) e centrifugadas a $300 \mathrm{~g}$ por 4 min à temperatura ambiente. Posteriormente, para evitar ligações inespecíficas, as células foram ressuspendidas com solução de bloqueio (5\% BSA - albumina de soro bovino em PBSA), incubadas por $30 \mathrm{~min}$ a $4^{\circ} \mathrm{C}$, centrifugadas a $300 \mathrm{~g}$ por $4 \mathrm{~min}$, ressuspendidas em PBSA a $4^{\circ} \mathrm{C}$ e contadas no citômetro. $10^{5}$ células foram tratadas com 
anticorpos anti-CD44-APC (BD) e/ou anti-CD24-PECy ${ }^{\mathrm{TM}} 7$ (BD).

Primeiramente, para avaliar a melhor concentração de anticorpo para cada linhagem, foram testadas 4 concentrações diferentes (1:50, 1:100, 1:200, 1:400) de cada anticorpo em $10^{5}$ células de cada linhagem proveniente de cultura aderente. Sabendo a diluição correta de cada anticorpo para cada linhagem, foi possível então avaliar a porcentagem das populações citadas acima. Para o anticorpo anti-CD44-APC as diluições utilizadas para MCF-7, SKBR3 e BT-474 foram 1:50. Já o anticorpo anti-CD24-PECyTM7, foi diluído 1:200 para a linhagem celular MCF-7 e 1:400 para BT-474 e SKBR3. Após a adição dos anticorpos diluídos as amostras foram incubadas a $4^{\circ} \mathrm{C}$ por 40 min protegidas da luz, depois lavadas com PBSA, centrifugadas a $4{ }^{\circ} \mathrm{C}$ por 5 min e ressuspendidas em tampão PBSA contendo FBS $1 \%$. As amostras foram fixadas com formaldeído $0,15 \%$ e mantidas a $4^{\circ} \mathrm{C}$ até sua leitura no citômetro.

As amostras foram filtradas com filtro de $70 \mu \mathrm{m}(\mathrm{BD})$ antes de serem introduzidas no aparelho. Como controles negativos foram utilizadas células não marcadas e como controles positivos foram utilizadas beads do kit BD ${ }^{\mathrm{TM}}$ CompBead Plus Anti-Mouse Ig (BD) que são esferas de poliestireno acopladas com imunoglobulinas que se ligam à cadeia leve de qualquer imunoglobulina de camundongo. Os controles positivos foram então compostos destas esferas incubadas com os anticorpos de camundongos anti-CD44 e anti-CD24, que são conjugados respectivamente com os fluoróforos APC e PECy7. As amostras foram analisadas no citômetro FACSCanto (BD), com o auxílio da técnica responsável pelo aparelho do CEFAPICB-USP

Os dados obtidos de todos os experimentos envolvendo citometria foram analisados com o programa FlowJo versão 10.0.5 (TreeStar, Ashland, OR, EUA).

\subsubsection{Extração de RNA, transcrição reversa e PCR em tempo teal}

Os mRNAs e miRNAs foram extraídos com o kit miRNeasy Mini (Qiagen), que permite o isolamento de ambas as populações de RNAs. Os RNAs foram quantificados no espectrofotômetro NanoDrop ${ }^{\circledR} N D-1000$ (NanoDrop) e tratados com 2U de Ambion ${ }^{\circledR}$ DNase (Life Technologies) em volume final de $50 \mu \mathrm{L}$, segundo as instruções do fabricante.

Para a transcrição reversa (RT) dos miRNAs foi utilizado o kit miScript Reverse Transcription (Qiagen), enquanto que para a RT dos mRNAs, foi utilizado o kit Superscript III First Strand (Life Technologies). Para ambas RTs, foram utilizados 500 ng de RNA total. As amplificações por qRT-PCR foram feitas utilizando SYBR Green com iniciadores específicos para amplificação dos transcritos em estudo. Para a determinação do melhor 
controle endógeno para a normalização dos mRNAs, foram avaliados nas linhagens estudadas os seguintes genes candidatos: ACTB, beta-glucuronidase (GUSB), gliceraldeído-3-fosfato desidrogenase (GAPDH), hipoxantina-guanina fosforribosil transferase (HPRT) e proteína ribossomal ácida humana (HuPO). Para as reações de amplificação dos mRNAs foi utilizado o kit Kapa SYBR ${ }^{\circledR}$ FAST qPCR Master Mix (Kapa Biosystems, Inc., Woburn, MA, EUA). Para a determinação do melhor controle endógeno para a normalização dos miRNAs foram avaliados alguns snoRNAs (small-nucleolar RNAs): RNU44, RNU48 e RNU6B, normalmente utilizados para este fim. Para as reações de amplificação dos miRNAs foi utilizado o kit QuantiTect SYBR Green PCR (Qiagen) com os iniciadores miScript Universal Primer e miSript Primer Assay, sendo este último específico para a sequência de interesse.

Para a determinação dos valores de expressão relativa dos mRNAs/miRNAs de interesse, foram feitos os seguintes cálculos:

$$
\begin{gathered}
\Delta \mathrm{Ct}=\mathrm{Ct}_{\text {gene alvo }}-\mathrm{Ct}_{\text {gene normalizador (para miRNA: RNU6B; para mRNA: GUSB) }} \\
\Delta \Delta \mathrm{Ct}=\Delta \mathrm{Ct}_{\text {amostra }}-\Delta \mathrm{Ct} \text { controle } \\
\text { Expressão relativa }=2^{-\Delta \Delta \mathrm{Ct}}
\end{gathered}
$$

Aos controles foi designado o valor 1 para o cálculo da expressão relativa das amostras. Assim, a expressão relativa da amostra foi obtida a partir da comparação dos níveis de expressão de cada um deles com o controle.

No Quadro 2, logo abaixo, encontram-se as sequências dos iniciadores de amplificação dos mRNAs utilizados nos experimentos. 
Quadro 2 - Sequências de iniciadores usados para a amplificação de mRNAs de interesse.

\begin{tabular}{lll}
\hline & \multicolumn{1}{c}{ Senso 5'-3, } & \multicolumn{1}{c}{ Iniciadores } \\
\hline HER2 & CCCTCTGAGACTGATGGCTACC & GCCGAACATCTGGCTGGTT \\
ACTB & GTGTTGTGGGTGTAGGTAC & CATGTCACACTGGGGAAG \\
HPRT & GAACGTCTTGCTCGAGATGTGA & TCCAGCAGGTCAGCAAAGAAT \\
GAPDH & GAAGGTGAAGGTCGGA & GGGTCATTGATGGCAAC \\
GUSB & GAAAATACGTGGTTGGAGAGCTCATT & CCGAGTGAAGATCCCCTTTTA \\
NANOG & CAAAGGCAAACAACCCACTT & TCTGGAACCAGGTCTTCACC \\
OCT4 & CGAAAGAGAAAGCGAACCAG & GCCGGTTACAGAACCACACT \\
SOX2 & GCACATGAACGGCTGGAGCAACG & TGCTGCGAGTAGGACATGCTGTAGG \\
LIN28 & GAAGCGCAGATCAAAAGGAG & GTAGGTTGGCTTTCCCTGTG \\
KLF4 & CTTCGTTGACTTTGGGGTTC & CGCTCTCCAGGTCTGTGG \\
CD510A & CGTGTACGGTGGGAGGTCTA & AGCGATCGCAGATCCTTG \\
\hline
\end{tabular}

\subsubsection{Superexpressão dos miRNAs}

\subsubsection{Características dos lentivetores baseados em HIV}

Os lentivetores baseados em HIV utilizados na superexpressão dos precursores dos miRNAs (pre-miRNA) -221, -222, -4728-3p e do lentivetor controle (scramble) foram customizados pela empresa System Biosciences (SBI, Mountain View, CA, EUA) que produz a terceira geração de lentivetores desenvolvidos para aplicações em terapia gênica (POESCHLA et al, 2003; SODROSKI et al, 1997; 1999; FEDERICO et al, 2003; HEISER et al, 2004; MACHIDA et al, 2003). Os pre-miRNAs foram clonados em plasmídeos CD516B1 (SBI) (Figura 9A, B, C e D) e as sequências dos clones foram verificadas pela empresa SBI através de iniciadores 5', que se ligam no promotor de CMV e iniciadores 3' que se ligam no promotor de EF1. As sequências dos miRNAs clonados assim como sua orientação foram novamente confirmadas por sequenciamento Sanger em nosso laboratório utilizando os iniciadores CD510A (Quadro 2).

Cada construto possui uma estrutura em loop que contém o pre-miRNA de interesse e regiões flanqueadoras de 200-400 pares de base (pb) de ambos os lados. Essa característica garante que os miRNAs expressos pelo construto sejam corretamente processados em miRNAs maduros na célula. O vetor possui um promotor de CMV e sinal de poli-adenilação de SV40, que garante uma terminação de transcrição eficiente além de expressão alta e estável. O vetor possui também o repórter fluorescente copRFP, cuja expressão é controlada 
por um promotor contendo um elemento responsivo a EF1, que é expresso na maioria dos tecidos e células.

A

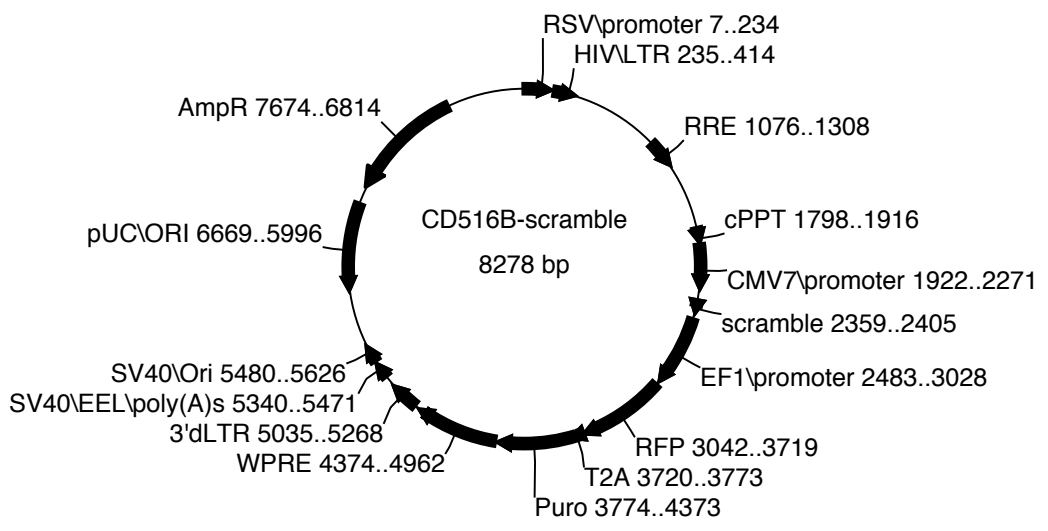

B

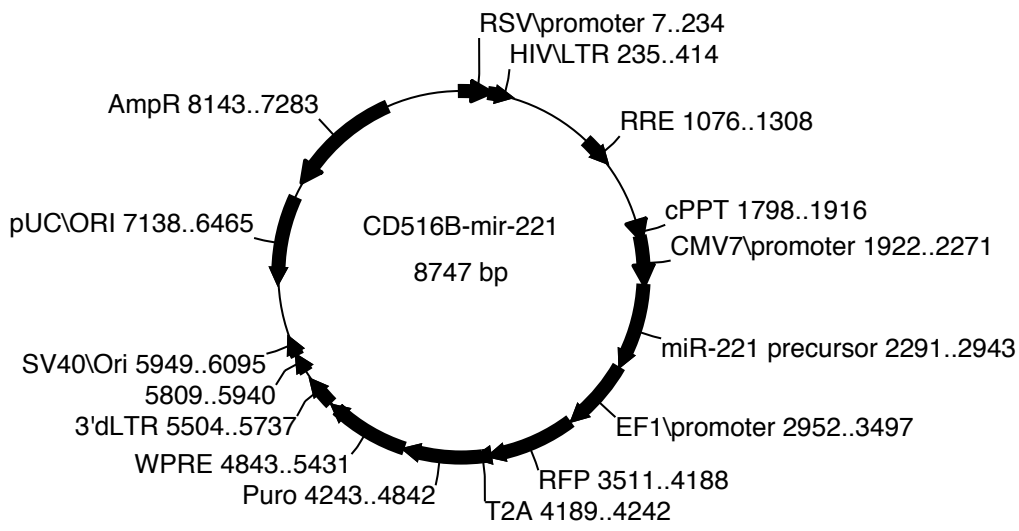

C

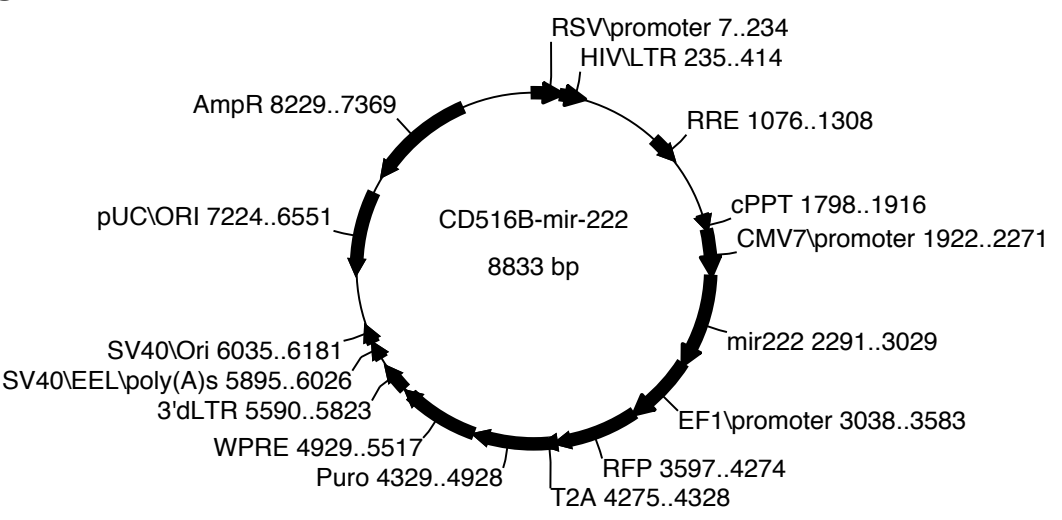


D

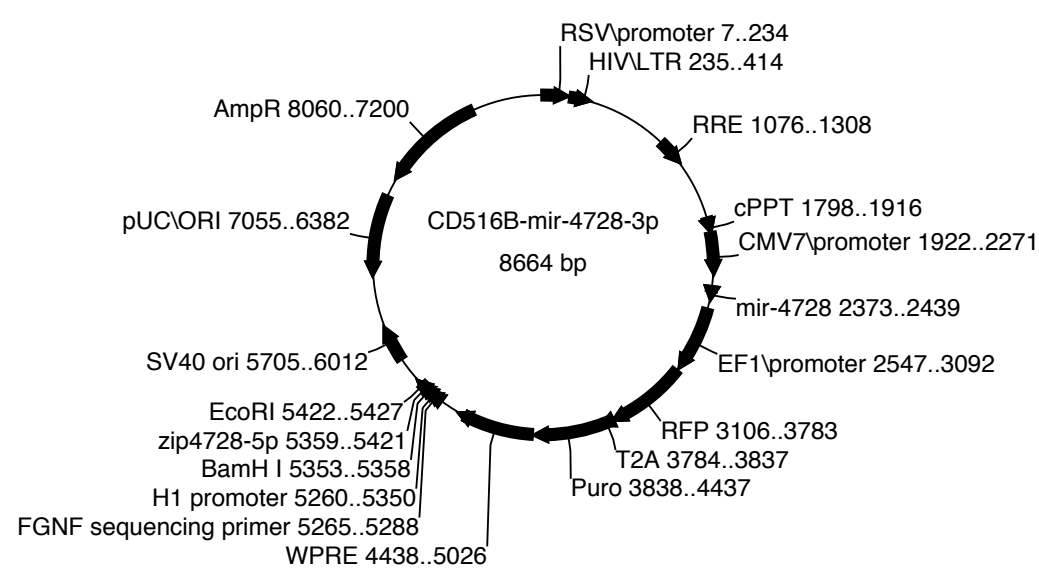

Figura 9 - Mapas de lentivetores de terceira geração baseados em HIV contendo insertos para a superexpressão de miRNAs precursores. Também são indicadas as sequências de promotores mais relevantes (resistência à ampicilina, RFP - red fluorescence protein- e outros). (A) Lentivetor controle de 8278 bp contendo inserto de sequência aleatória de 46 bp. (B) Lentivetor de $8747 \mathrm{bp}$ contendo inserto do precursor miRNA-221 de $652 \mathrm{bp}$. (C) Lentivetor de 8833 bp contendo inserto do precursor miRNA-222 de 738 bp. (D) Lentivetor de 8664 bp contendo inserto do precursor miRNA-4728 de 66 bp e um inserto zip4728-5p que produz sequência antisense para knockdown de 4728-5p.

A seguir encontram-se importantes regiões contidas nos lentivetores acima e suas funções:

-Elemento WPRE - aumenta a estabilidade e a tradução de transcritos dirigidos por CMV.

- Sinal de poliadenilação SV40 — permite a terminação eficiente da transcrição e processamento de transcritos recombinantes.

-Promotor híbrido RSV-5'LTR - Para vetores baseados no HIV. Fornece um alto nível de expressão do transcrito viral completo em células empacotadoras virais da linhagem celular 293.

- Elementos genéticos (cPPT, GAG, LTRs) - necessários para o empacotamento, transdução, e integração estável do construto de expressão viral no DNA genômico da célula.

-SV40 origin - para propagação estável do plasmid em células de mamíferos.

-pUC origin - para replicação de alta cópia e manutenção do plasmídeo em E.coli.

- Gene de resistência à ampicilina $(\mathrm{AmpR})$ - para a seleção em E.coli.

- RFP - (do inglês: red fluorescence protein) marcador fluorescente para monitorar/separar células positivas após a transfecção e a transdução.

- EF1 - promotor que controla a expressão de RFP, é expresso na maioria de tecidos e 
células.

O miRNAs primários (pri-miRNAs) expressos por esses lentivetores resultam em premiRNAs e, posteriormente em miRNAs maduros através da maquinaria de processamento da célula hospedeira.

Cada construto possui uma estrutura de em loop que contém o pre-miRNA de interesse e regiões flanqueadoras de 200-400 pares de base (pb) de ambos os lados, nessa fase é chamado de pri-miRNA. Essa característica garante que os miRNAs expressos pelo construto sejam corretamente processados em miRNAs maduros na célula.

Os pri-miRNAs são processados ainda no núcleo pela enzima RNase III DROSHA, que elimina as regiões flanqueadoras resultando em um transcrito menor em forma de grampo, o pre-miRNA de aproximadamente 70 nucleotídeos. O pre-miRNA é exportado para o citoplasma pelo complexo Exportina-5/Ran-GTP, onde é clivado pela enzima DICER, gerando transcritos de fita dupla de 19 a 25 nt denominados miRNAs maduros (HE; HANNON, 2004). Este produto é incorporado a um complexo multimérico denominado RISC (do inglês RNA-induced silencing complex), que inclui a proteína Argonauta como um de seus principais componentes. Apenas uma das fitas do duplex de miRNA permanece no RISC para o posterior pareamento com o mRNA-alvo (GUO; LU, 2010) (Figura 10). 

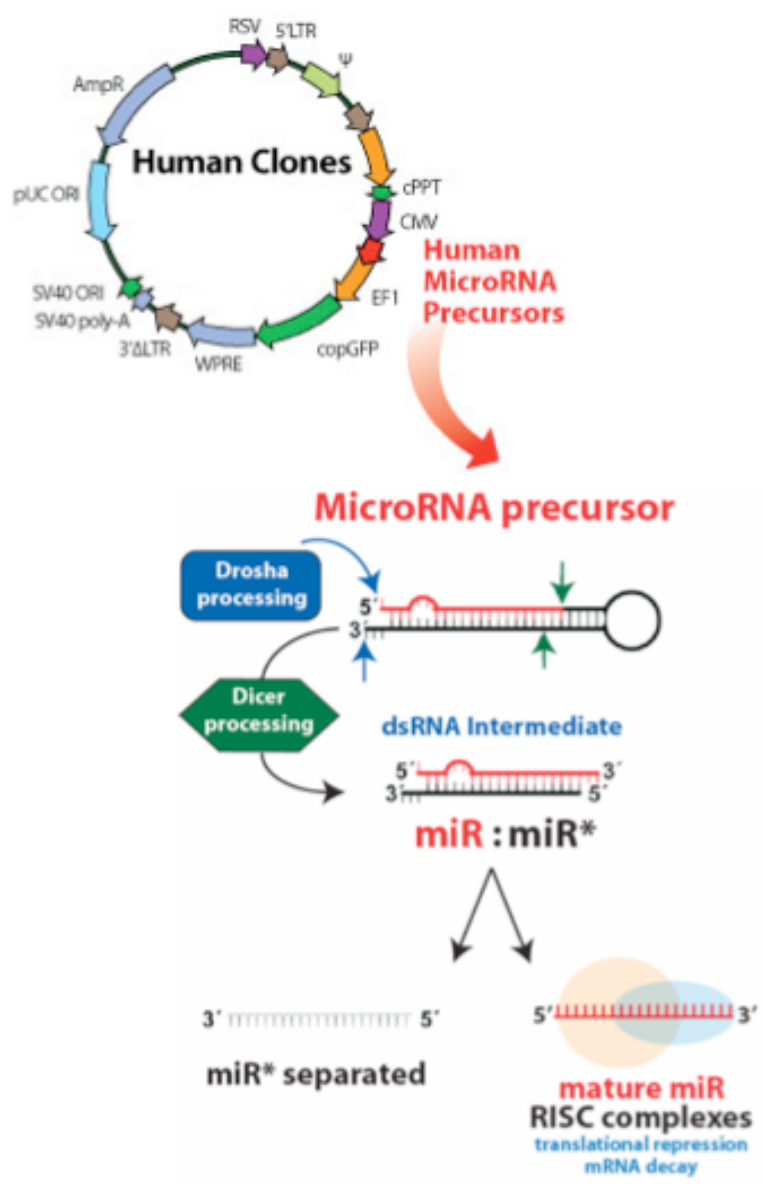

Figura 10 - Esquema ilustrando o lentivetor usado para a produção dos miRNAs precursores. Lentivetor que, através da maquinaria celular e atividade da RNase III DROSHA, produz miRNAs precursores. Os miRNAs precursores de aproximadamente 70 nucleotídeos, após o processamento da enzima DICER, geram transcritos de fita dupla de 19 a 25 nucleotídeos denominados miRNAs maduros. Apenas uma das fitas do duplex de miRNA permanece no RISC para o posterior pareamento com o mRNA-alvo. Fonte: site SBI - Human and Mouse Lenti-miR TM MicroRNA Precursor Clone Collections (2010).

\subsubsection{Purificação de plasmídeos}

Para a purificação em larga-escala foi realizado o pré-inóculo a partir da obtenção de colônias isoladas de bactérias E.coli cultivadas em $3 \mathrm{ml}$ de meio LB (Luria Bertani: NaCl 170 $\mathrm{mM}$, triptona $1 \%$, extrato de levedura $0,5 \%, \mathrm{pH} 7,5)$ em presença de ampicilina $100 \mathrm{ug} / \mathrm{mL}$. Após $8 \mathrm{~h}$ de cultivo a $37^{\circ} \mathrm{C}$ em agitação contínua de $250 \mathrm{rpm}$ em agitador orbital Gallenkamp modelo 10X 400 (Gallenkamp, Surrey, UK) foi realizado o inóculo utilizando $100 \mu \mathrm{L}$ do préinóculo em $100 \mathrm{~mL}$ de meio LB (igual ao do pré-inóculo). Após $12 \mathrm{~h}$ de cultivo a $37^{\circ} \mathrm{C}$ sob agitação nas mesmas condições do cultivo do pré-inóculo, a cultura foi centrifugada a $6000 \mathrm{x}$ g por 15 min a $4^{\circ} \mathrm{C}$ e, posteriormente foi iniciada o procedimento para a obtenção dos plasmídeos purificados através do kit EndoFree Plasmid Maxi kit (Qiagen) segundo as 
instruções do fabricante. Os plasmídeos foram quantificados no espectrofotômetro NanoDrop ${ }^{\circledR}$ ND-1000 (NanoDrop).

\subsubsection{Produção de lentivírus}

Para a produção lentivírus foi necessária a co-transfecção transiente na linhagem 293T/17 de três plasmídeos contidos no pPACKH1 Packaging Plasmid Mix (SBI), além de cada um dos plasmídeos de interesse que codificam os genes dos miRNAs juntamente com a proteína RFP (vetores: CD516B-scramble; CD516B-mir-221; CD516B-mir-222 e CD516Bmir-4728-3p). Os três plasmídeos necessários à formação das estruturas virais contidos no pPACKH1 Packaging Plasmid Mix são: pPACKH1-GAG, pPACKH1-REV e pVSV-G (Figura 11).

O plasmídeo pPACKH1-GAG contém genes estrutural ( $g a g)$ e de replicação (pol) que codificam algumas das proteínas requeridas na produção de lentivírus e também o gene env que codifica para o envelope protéico que define o tropismo.

O plasmídeo pPACKH1-REV contém gene rev (do inglês: Regulator of Expression of Virion Proteins) que codifica a para proteína regulatória que é requerida para a replicação do HIV.

O plasmídeo pVSV-G expressa a glicoproteína do envelope do vírus da estomatite vesicular (VSV-G) a partir do promotor CMV. Partículas virais de pseudotipos VSV-G medeiam a infecçãoo viral através de ligação de lipídios e fusão de membranas plasmáticas e, dessa forma, podem infectar células de mamíferos e outro tipos celulares (BURNS, 1993). 


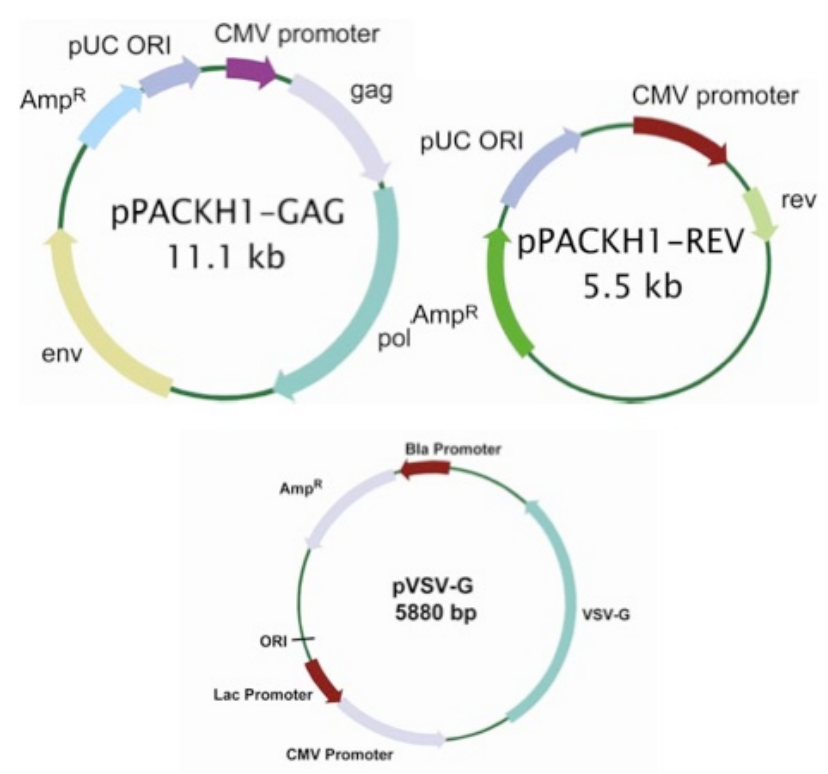

Figura 11 - Mapas funcionais dos plasmídeos contidos no $p P A C K H 1$ Packaging Plasmid Mix. Plasmídemos de empacotamento viral pPACKH1-GAG (em cima à esquerda) e pPACKH1-REV (em cima à direita) e plasmídeos pVSV-G (abaixo).

Fonte: Manual do usuário: Lentivector Expression Systems: Guide to Packaging and Transduction of Target Cells. Systems Biosciences (SBI).

A co-transfecção transiente destes plasmídeos foi realizada na linhagem 293T/17 uma linhagem empacotadora de vírus estabelecida e que possui todos os fatores genéticos necessários para a produção de altos títulos das partículas virais (MILLER; CHEN, 1996).

Para a co-transfecção, 4,5 x $10^{6}$ células $293 \mathrm{~T} / 17$ foram colocadas em meio completo sem antibiótico em garrafas de $75 \mathrm{~cm}^{2}$ previamente tratadas com poli-lisina (hidrobrometo de poli-D-lisina - Sigma-Aldrich) durante $1 \mathrm{~h}$ a $37^{\circ} \mathrm{C}$ lavadas três vezes com PBS. No dia seguinte, trocou-se o meio, colocando $5 \mathrm{~mL}$ de meio DMEM 10\% FBS sem antibiótico. Em seguida, foi realizada a transfecção na presença de $36 \mu \mathrm{L}$ de Lipofectamina ${ }^{\circledR}$ (Life Technologies) conforme as instruções do fabricante com as quantidades padronizadas de plasmídeos tanto do pPACKH1 Packaging Plasmid Mix (6 $\mu \mathrm{g})$ como dos plasmídeos de interesse $(3 \mu \mathrm{g})$. Após a transfecção, os sobrenadantes foram coletados, centrifugados a 3000 $\mathrm{x}$ g por 15 min à temperatura ambiente e o sobrenadante da centrifugação foi filtrado em filtro MILLEX-HV (Millipore Corp., Billerica, MA, EUA) de $0.45 \mu \mathrm{m}$ de PVDF (fluoreto de polivinilideno) para logo ser utilizado na transdução nas células-alvo.

Para a determinação do maior título viral obtido a partir da co-transfecção transiente dos plasmídeos, foram coletados amostras de sobrenadante do meio da 293T/17, que continham as partículas virais do construto para a superexpressão do miR-222, nos tempos de 24, 48 e 72h após a co-transfecção. A intensidade de fluorescência emitida pela RFP foi 
avaliada através de imagens de microscopia de fluorescência capturadas em 24, 48 e 72h após a co-transfecção e foi realizada a titulação viral das amostras nesses diferentes tempos.

\subsubsection{Titulação viral}

As titulações virais foram feitas por qRT-PCR utilizando o kit UltraRapid Lentiviral Titer (SBI), que contém um iniciador para a sequência WPRE presente em qualquer construto baseado em HIV proveniente da SBI e um outro iniciador universal para a região ultra conservada do gene SYNCRIP utilizado como uma referência interna para o cálculo do MOI (multiplicidade de infecção, do inglês: Multiplicity Of Infection).

A curva de calibração foi realizada com amostras de DNA genômico (gDNA) de células transduzidas com MOIs previamente determinadas pelo fornecedor: MOIs 0, 0.52, 1.22, 2.4, 5.4 e 10.3). Através do cálculo de MOI é possível calcular a concentração viral de determinada amostra. Portanto, para determinar o título viral das amostras, foi necessário determinar os valores de MOI a partir gDNAs derivados de células 293T/17 transduzidas com sobrenadantes contendo partículas virais coletadas em 24, 48 e $72 \mathrm{~h}$ após a co-transfecção transiente. Os pontos da curva de calibração com MOIs previamente conhecidos foram amplificados simultaneamente com as nossas amostras.

A curva de calibração mostra a correlação entre os valores de MOI das amostras fornecidas pelo fabricante e os valores $2^{-\Delta \mathrm{CT}}$ de cada amostra são obtidos na reação de $\mathrm{qRT}$ PCR através do cálculo:

$$
\Delta \mathrm{Ct}=\mathrm{Ct}_{\mathrm{WPRE}}-\mathrm{Ct}_{\mathrm{SYNCRIP}}
$$

Para determinar o valor de MOI, foi utilizada a equação da reta $(\mathbf{y}=\mathbf{a x}+\mathbf{b})$ feita no Excel com o qual é obtido o valor de a (coeficiente angular), $\mathbf{x}$ o valor dado por $2^{-\Delta \mathrm{CT}}$ de cada amostra analisada e y é o valor de MOI a ser determinado para cada amostra. $\mathrm{O}$ valor de b é o coeficiente linear, onde a reta corta o eixo y, nesse caso 0 (MOI de 0). A partir da determinação dos valores de MOI (multiplicação de a pelo valor de $2^{-\Delta \mathrm{CT}}$ ) dos sobrenadantes foi possível determinar a concentração de partículas virais (IFU/mL) presentes nos sobrenadantes através da seguinte equação: $\left(\mathrm{MOI}_{\text {amostra }}\right)$ x (número de células utilizados no momento da transdução) $\times 1000 / \mu 1$ de sobrenadante contendo partículas virais para a transdução. 
As reações de qRT-PCR foram feitas com $2 x$ SYBR Taq mix (SBI) presente no kit para um volume final de $10 \mu \mathrm{L}$.

\subsubsection{Transdução viral nas células-alvo}

Para a transdução das partículas virais nas células-alvo, foram plaqueadas $10^{4}$ células das linhagens MCF-7, SKBR3 e BT-474 em placas de 96 poços, e no dia seguinte foram adicionados os volumes de 10, 20, 50100 e $200 \mu \mathrm{L}$ de sobrenadantes coletados 48h após a co-transfecção da 293T/17. Após a observação no microscópio de fluorescência das células transduzidas, estas foram coletadas de acordo com o volume de sobrenadante viral utilizado que não foi capaz de infectar $100 \%$ das células, já que nesse caso, a probabilidade de apenas uma partícula viral se integrar no genoma de uma célula é maior. As células transduzidas foram separadas por citometria.

\subsubsection{Ensaio de proliferação}

No primeiro dia, $3 \times 10^{3}$ células foram plaqueadas em meio completo (meio, soro $10 \%$ v/v e antibiótico $1 \% \mathrm{v} / \mathrm{v}$ ) em um volume final de $200 \mu \mathrm{L}$ em placas do tipo E-plate, próprias do aparelho $x C E L L i g e n c e$, modelo RTCA DP (Roche, Indianapolis, Indiana, EUA). O sistema do XCelligence (ACEA Biosciences, EUA) possui biosensores microeletrônicos capazes de medir a impedância elétrica da população celular plaqueada nos poços das placas que possuem microeletodos de ouro. As células em contato com estes sensores mudam a impedância elétrica entre os microeletrodos, o que se traduz em informações quantitativas em tempo-real sobre o status celular, incluindo número, viabilidade e morfologia.

No dia seguinte, a fim de carenciar as células, o meio completo foi retirado, os poços foram lavados com PBS 1x e foi adicionado apenas o meio de cultura. No terceiro dia o meio foi trocado por meio com soro $2 \%$, e, após $48 \mathrm{~h}$, observado o efeito, foram adicionados aos $200 \mu \mathrm{L}$ mais $20 \mu \mathrm{L}$ de soro, sendo a concentração de soro final foi aproximadamente 10,9\% (já contabilizando o soro já existente). Este experimento foi monitorado em intervalos de $1 \mathrm{~h}$ em todo seu curso em tempo real. Os dados gerados foram adquiridos e gravados automaticamente durante todo o curso do experimento.

O experimento teve uma duração total de $165 \mathrm{~h}$, sendo que para os resultados apresentados neste trabalho foram coletados os dados referentes ao intervalo de tempo de 127-161h após a estabilização das culturas após as sucessivas trocas de meio de cultivo. Foi 
calculada a inclinação da reta (slope) gerada a partir dos valores de índices celulares da média das triplicatas de cada população celular neste intervalo de tempo.

\subsubsection{Ensaio de citotoxicidade}

A fim de determinar os valores de IC50 dos quimioterápicos paclitaxel e trastuzumabe, $5 \times 10^{3}$ células wt foram plaqueadas em volume final de $100 \mu \mathrm{L}$ de meio completo em placas de 96 poços.

No dia seguinte, a células foram tratadas com paclitaxel nas seguintes concentrações (diluições seriadas): $0 ; 0,976 ; 1,953 ; 3,906 ; 7,812 ; 15,625 ; 31,25 ; 62,5 ; 125 ; 250 \mathrm{ng} / \mathrm{mL}$ ou com trastuzumabe nas seguintes concentrações: $0 ; 1,8 ; 3,75 ; 7,5 ; 15 ; 30 ; 60 ; 120 ; 240$ e 480 $\mu \mathrm{g} / \mathrm{mL}$.

No quinto dia (72h após o tratamento), o meio foi trocado por $100 \mu \mathrm{L}$ de meio completo $10 \%(\mathrm{v} / \mathrm{v})$ MTT (Sigma-Aldrich) a $5 \mathrm{mg} / \mathrm{mL}$. As placas foram incubadas por $3 \mathrm{~h} \mathrm{a}$ $37^{\circ} \mathrm{C}$, o meio foi trocado por $100 \mu \mathrm{L}$ de isopropanol $100 \%$ e as placas foram incubadas por 15 min a temperatura ambiente. Após esse intervalo as placas foram lidas no espectrofotômetro de placas SpectraMax M5 (Molecular Devices, Sunnyvale, CA, EUA) nos comprimentos de onda de $570 \mathrm{~nm}$ e $630 \mathrm{~nm}$. Esse experimento foi realizado em 6 replicatas de cada condição.

Os dados foram analisados através do programa GraphPad Prism versão 6.0 (GraphPad Software, Inc.).

\subsection{Resultados e discussão}

As linhagens MCF-7, BT-474 e SKBR3 foram escolhidas para este trabalho devido aos diferentes níveis de expressão de HER2 que elas apresentam. A MCF-7 expressa níveis muito baixos de HER2, sendo até considerada negativa para HER2, já a linhagem BT-474 apresenta níveis intermediários de HER2, enquanto a SKBR3 apresenta alta expressão desse receptor. 


\subsubsection{Características morfológicas de mamosferas derivadas de linhagens celulares de mama}

As linhagens celulares MCF-7, SKBR3 e BT-474 foram cultivadas em condição de células aderentes (Figura 12 D-E) e também em condições de formação de mamosferas (Figura 12 A-C).

As mamosferas formadas a partir da linhagem celular BT-474 eram maiores que as mamosferas geradas pelas linhagens celulares MCF-7 e SKBR3 (Figura 12 A-C). Tais mamosferas se mostraram ainda mais regulares, mais organizadas e mais agregadas quando comparadas com as mamosferas das outras duas linhagens celulares. Da mesma forma, a quantidade de mamosferas formadas em BT-474 foi maior, seguida de MCF-7 das mamosferas de SKBR3.

As mamosferas derivadas de SKBR3 apresentaram um formato mais irregular, desorganizado e desagregado em comparação com as mamosferas das outras linhagens.

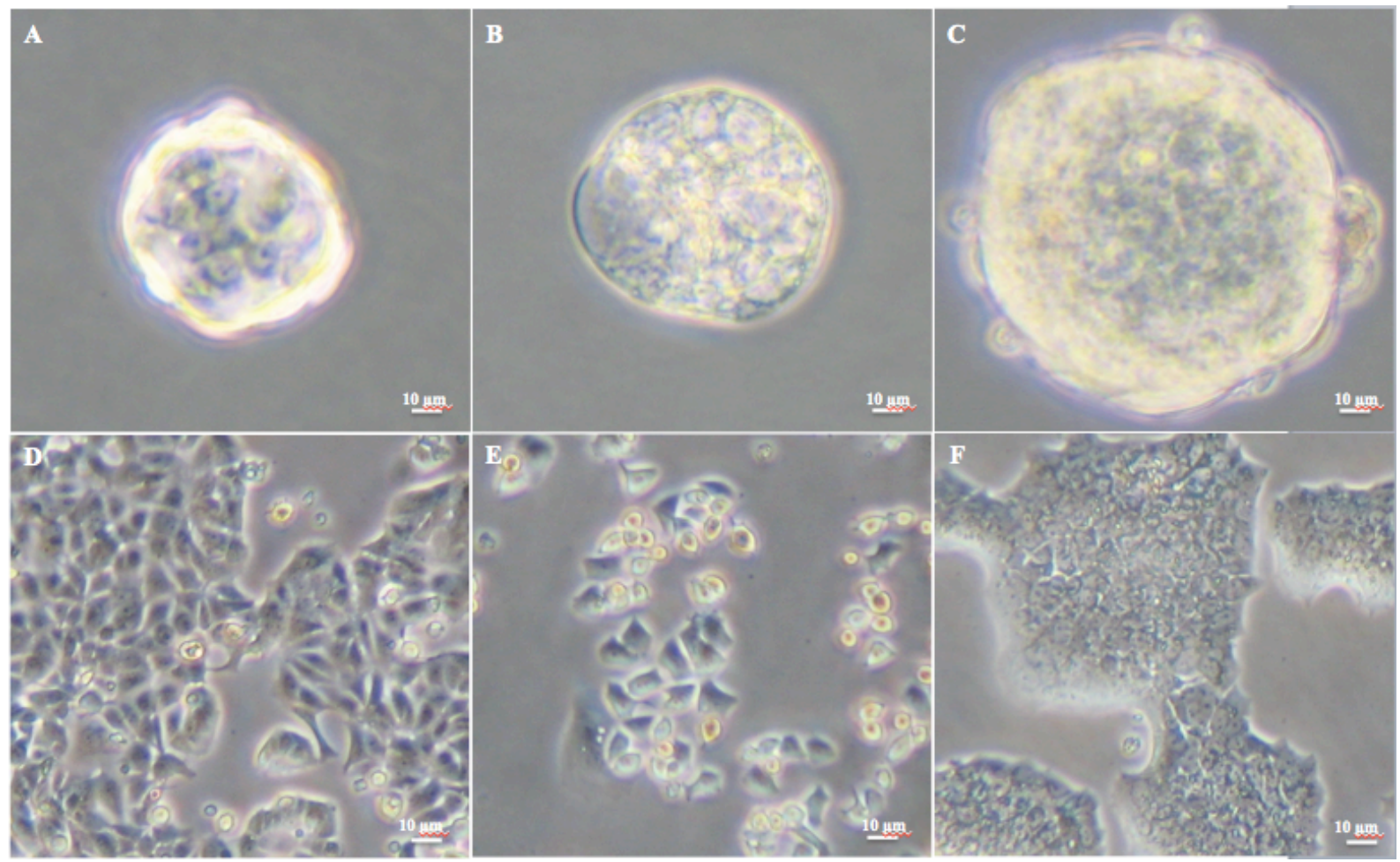

Figura 12 - Cultura de mamosferas e de células aderentes derivadas das linhagens MCF-7, SKBR3 e BT-474. Cultura de mamosferas (A-C) e de células aderentes (D-F). MCF-7 (A,D), SKBR3 (B,E) e BT-474 (C,F).

Segundo Prud'homme et al., (2010), o formato e a aparência das esferas são dependentes de características das linhagens celulares que as originaram. No estudo realizado 
por este grupo foi demonstrado que células da linhagem BT-474 $\left(\mathrm{ER}^{+} / \mathrm{PR}^{+} / \mathrm{HER}-2^{+}\right.$, triplopositiva) quando colocadas em condição de crescimento de mamosferas formam esferas uniformes, mais redondas e firmes do que células da linhagem MDA-MB-231 (ER $/ \mathrm{PR}^{-} / \mathrm{HER}-2^{-}$, triplo-negativa), que por sua vez, possuem um formato mais frouxo e irregular.

Outro estudo também demonstrou que as linhagens ER+ MCF-7 e BT-474 formam esferas mais firmes e arredondadas, quando comparadas com células de fenótipo mais agressivo, as quais apresentam formato semelhante a "cachos de uva" (grape-like) (BORGNA et al., 2012), tal como pôde ser observado nas mamosferas da linhagem SKBR3 não-luminal, ER- e que superexpressa HER2 (PIGOTT et al., 2011).

\subsubsection{Análises da expressão endógena de genes de interesse}

Após as análises morfológicas das mamosferas derivadas das linhagens estudadas, o objetivo foi a realização de análises moleculares dessas células cultivadas em condições aderentes e de mamosferas.

\subsubsection{Determinação de controles endógenos}

Para as análises moleculares subsequentes de mRNAs, foi necessária uma avaliação preliminar da expressão de genes que pudessem ser usados como controles endógenos em células tumorais de mama, a fim de determinar o controle endógeno cuja expressão entre as linhagens seria a menos variável. Foram testados 5 genes: ACTB, GAPDH, GUSB, HPRT e HuPO (MCNEILL; MILLER; KERIN et al., 2007; KHEIRELSEID et al., 2010). Abaixo encontra-se o gráfico mostrando a variação da expressão destes genes nessas linhagens. 


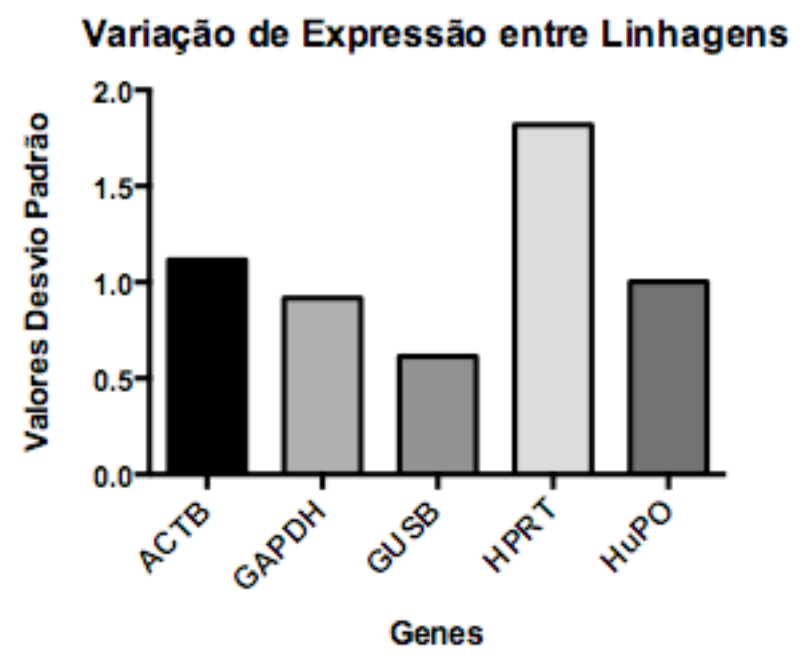

Figura 13 - Variação da expressão dos genes ACTB, GAPDH, GUSB, HPRT e HuPO entre as linhagens estudadas. Valores de desvio padrão extraídos a partir do cálculo da média (duplicata) dos valores de $\mathrm{Ct}$ (threshold cycle) de todas as linhagens para cada gene.

Para as análises de expressão de miR-221, -222 e -4728-3p, também foi necessária a determinação do controle endógeno mais adequado. Portanto, foram testados três genes utilizados como controles endógenos em células tumorais de mama no estudo de expressão de miRNAs, que são os small nucleolar RNAs (snoRNAs): RNU44, RNU48 (DAVOREN et al., 2008) e o small nuclear RNA (snRNA): RNU6B (GEE et al., 2011; KIM et al., 2012; NG et al., 2013) (Figura 14).

\section{Variação da Expressão entre as Linhagens}

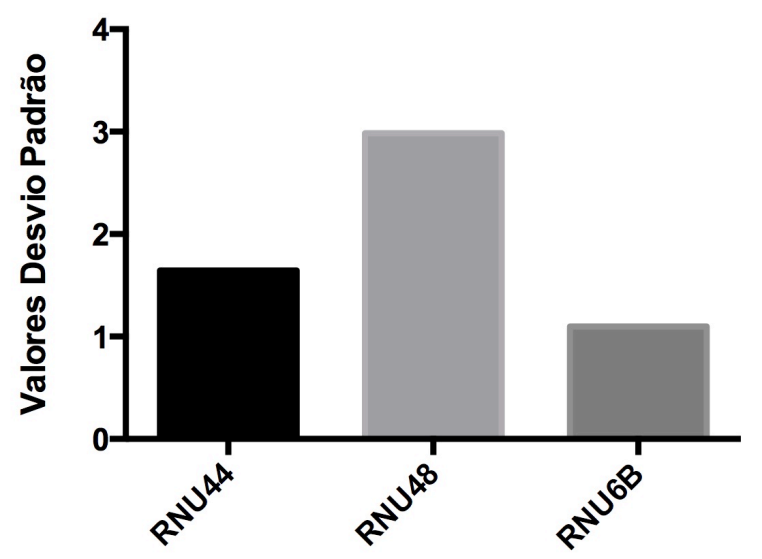

Figura 14 - Variação da expressão dos genes RNAs (snoRNAs): RNU44, RNU48 e o small nuclear $R N A$ (snRNA): RNU6B entre as linhagens estudadas. Valores de desvio padrão extraídos a partir do cálculo da média (duplicata) dos valores de $\mathrm{Ct}$ (threshold cycle) de todas as linhagens para cada gene.

Conforme a figura acima, o gene RNU6B foi selecionado como o controle endógeno mais adequado para a normalização das reações, pois este mostrou resultados menos variáveis 
quando comparado aos outros dois candidatos (RNU44 e RNU48), avaliados em MCF-7, SKBR3 e BT-474.

\subsubsection{Expressão de marcadores de pluripotência em mamosferas}

Em geral, o tempo para a formação de mamosferas é de aproximadamente 7 dias (DONTU; WICHA, 2005), neste ponto elas podem ser desagregadas em células únicas e colocadas novamente em cultura por mais 7 dias para a formação de mamosferas de $2^{\text {a }}$ geração e assim por diante. Alguns trabalhos mostram o enriquecimento proporcional ao tempo e às gerações (ROBERTSON et al., 2010). A auto-renovação é demonstrada a partir da formação de mamosferas após passagens seriais (CLARKE; WICHA. 2003).

Neste trabalho, as mamosferas foram cultivadas por diferentes períodos de tempo a fim de verificar o perfil de expressão de marcadores de células-tronco embrionárias, também chamados de fatores de reprogramação de iPS, em diferentes tempos e gerações. Portanto, a seguir, foi investigada a expressão dos marcadores de células-tronco embrionárias $S O X 2$, OCT4, NANOG, LIN28 e KLF4 (YU et al., 2007) por qRT-PCR nas linhagens cultivadas em condição aderentes e de mamosferas que foram cultivadas por 7, 14, 21 e 28 dias (aqui denominadas, respectivamente, M7, M14, M21 e M28) (Figura 15).

Às células aderentes foi designado o valor 1 para o cálculo da expressão relativa das mamosferas de diferentes gerações (M7, M14, M21 e M28). Dessa forma, a expressão relativa das mamosferas foi obtida a partir da comparação dos níveis de expressão de cada uma das gerações com células aderentes. 
MCF-7
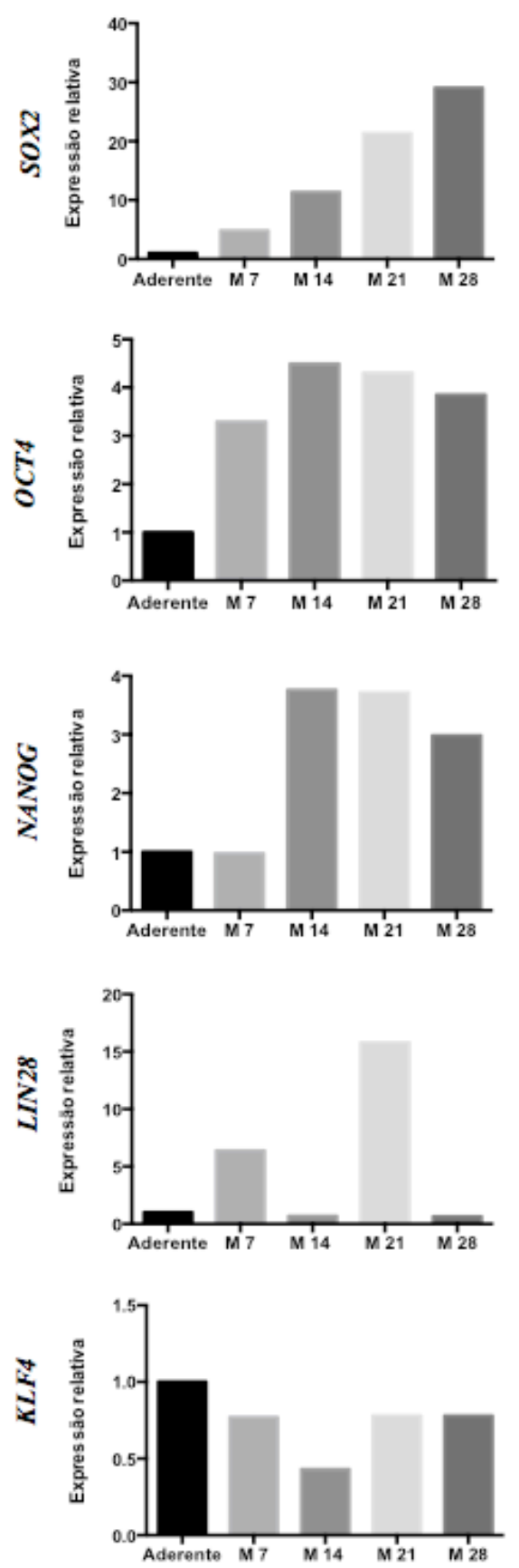

SKBR3
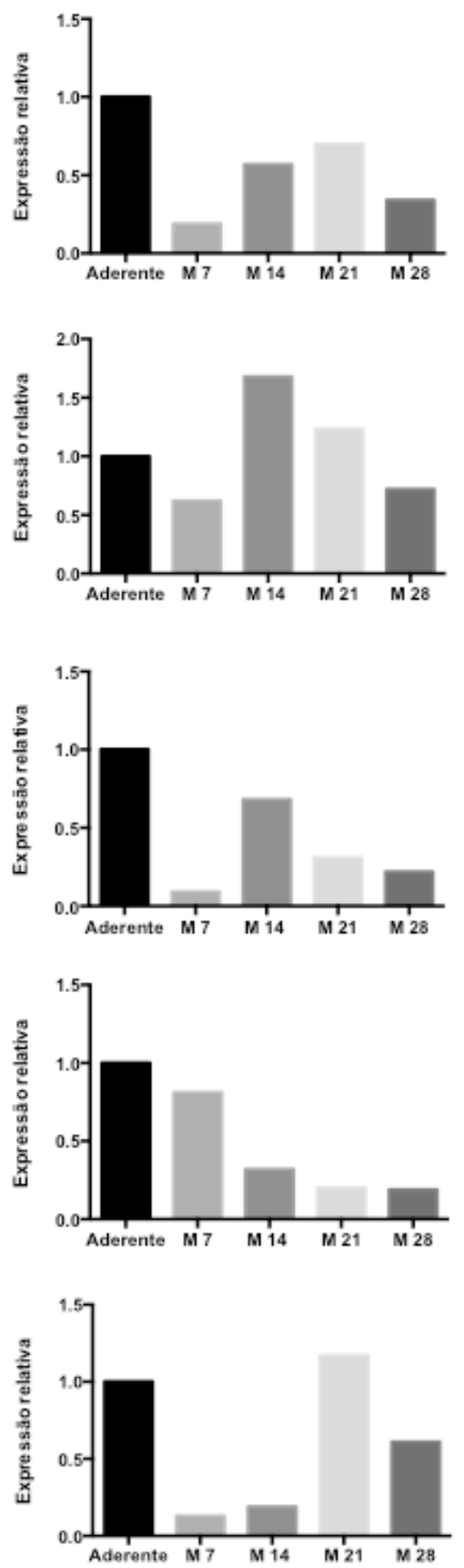

BT-474
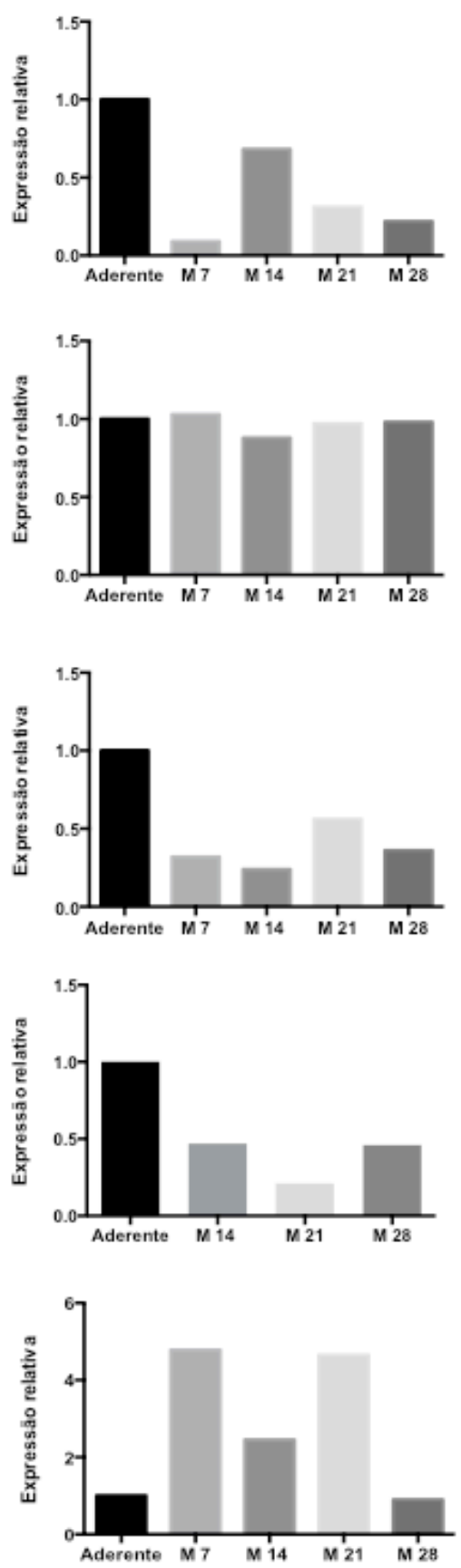

Figura 15 - Análise da expressão relativa dos genes $S O X 2$, OCT4, NANOG, LIN28 e KLF4 em células das linhagens MCF-7, BT-474 e SKBR3 aderentes e derivadas de mamosferas. Mamosferas de 7 (M7), 14 (M14), 21 (M21) e 28 dias (M28) de cultivo.

Conforme a Figura 15, nas mamosferas derivadas de MCF-7, foi observado um aumento consistente da expressão de $S O X 2$, OCT4 e NANOG, (resultados em concordância com o Capítulo I), além do aumento da expressão de LIN28 em M7 e M21.

SOX2, OCT4 e NANOG estão relacionados com tumores humanos fracamente diferenciados (BEN-PORATH et al., 2008). 
Para a linhagem SKBR3, OCT4 mostrou-se elevado nos pontos M14 e M21, assim como o marcador KLF4 também em M21 (Figura 15).

Para a linhagem BT-474, o gene KLF4 apresentou níveis aumentados em relação às células aderentes em três das quatro gerações de mamosferas: M7, M14 e M21. Foi observada uma grande variabilidade na expressão dos marcadores de pluripotência entre as linhagens celulares cultivadas em condições de mamosferas, avaliadas em quatro gerações ao longo das quatro semanas de cultivo (Figura 15).

Alguns relatos da literatura descrevem a ausência de expressão de alguns destes mesmos marcadores em alguns tipos de células-tronco, como no caso das células-tronco mesenquimais, que são células multipotentes capazes de se diferenciar em cartilagem, gordura e ossos. Estas células, que foram isoladas de medula óssea humana, só expressam NANOG após seu cultivo in vitro (PIERANTOZZI et al., 2011). Deste modo, a variação na expressão destes marcadores é algo esperado.

Leis et al., (2012) investigaram a expressão das proteínas codificadas pelos três fatores de transcrição, conhecidos comp reguladores principais de pluripotência: OCT4, SOX2 e NANOG. Apenas SOX2 se mostrou expresso em mamosferas derivadas de tumores e de linhagens celulares, e mesmo assim, em apenas algumas células. Interessantemente, os resultados obtidos por Leis et al., 2012 com o aumento da expressão de SOX2 em MCF-7 ao longo do tempo de cultivo foram idênticos aos observados em nossos experimentos avaliados por qRT-PCR (Figura 15).

O fato de haver variabilidade na expressão dos marcadores de pluripotência avaliados pode indicar que os marcadores de pluripotência avaliados não os mais adequados para a identificação de CSC nas linhagens tumorais de mama aqui analisadas. Resultados anteriores mostraram que em câncer de pulmão, os marcadores de células-tonco LIN28, KLF4, SOX2, OCT4 e NANOG apresentam diferentes padrões de expressão dependendo do tipo histológico estudado (MOREIRA et al., 2010).

Resultados de estudos anteriores sugeram que LIN28 mantém a pluripotência de células-tronco e progenitoras embrionárias e somáticas através do bloqueio da maturação de let-7 (VISWANATHAN; DALEY; GREGORY et al., 2008; BALZER et al., 2010), porém ainda não se sabe o papel de LIN28 no contexto de câncer (YANG et al., 2010). 


\subsubsection{CD44 e CD24 em mamosferas}

Ainda não existe um consenso na literatura em relação aos marcadores de CSCs mais adequados para células de mama. No entanto, diversos trabalhos mostram que CD44+, CD24/baixa e $\mathrm{ALDH}^{+}$são biomarcadores utilizados recentemente para identificar e caracterizar estas células (DE BEÇA et al., 2013).

Deste modo, neste trabalho foram realizadas análises na tentativa de contribuirmos com esta área, investigando qual a parcela das células totais de cada linhagem estudada apresenta o fenótipo de interesse inicial $\left(\mathrm{CD} 44^{+} / \mathrm{CD} 24^{-/ \text {baixa }}\right)$. Para isto, foram realizadas análises dos marcadores de células-tronco tumorais de mama CD44 e CD24 em células wt aderentes e também em células derivadas de mamosferas de $1^{\text {a }}$ geração (M7) (Figura 16)

A

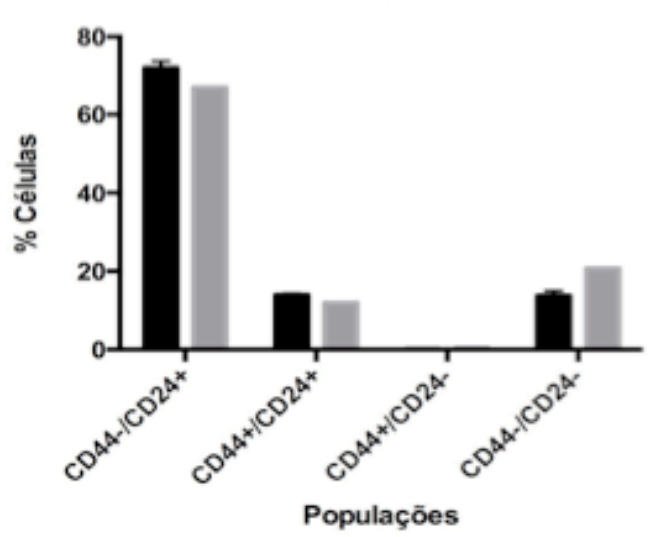

$\mathrm{C}$
B
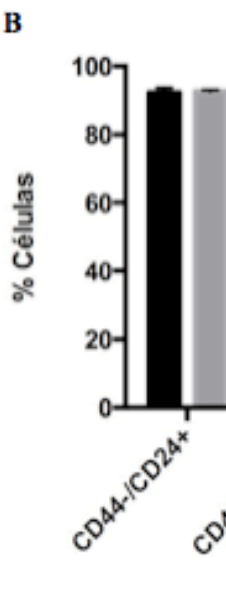

BT-474

SKBR3

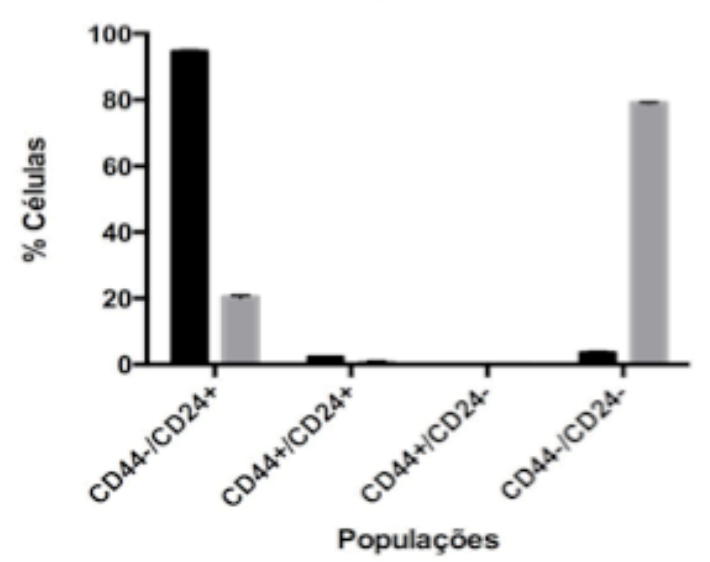

Figura 16 - Porcentagem das populações CD $44^{-} / \mathrm{CD} 24^{+}, \mathrm{CD} 44^{+} / \mathrm{CD} 24^{+}, \mathrm{CD} 44^{+} / \mathrm{CD} 24^{-}, \mathrm{CD}_{4} 4^{-} / \mathrm{CD}^{-} 4^{-}$ em células aderentes e derivadas de mamosferas de $1^{\text {a }}$ geração das linhagens MCF-7, BT-474 e SKBR3. Linhagens (A) MCF-7, (B) BT-474 e (C) SKBR3. 
Conforme apresentado na Figura 16, a população $\mathrm{CD} 44^{-} / \mathrm{CD} 24^{+}$constitui a grande maioria das células aderentes de todas as linhagens avaliadas (MCF-7: 72,10\%; BT-474: 92,25\%; SKBR3 94,5\%). Isto se repetiu nas células derivadas de mamosferas de MCF-7 (67\%) e BT-474 (92,6\%) (Figura 16A e B). Diferentemente de SKBR3 que apresentou nas mamosferas 19,8\% de células CD44\%CD24+ e 79\% de células CD44\%CD24- (Figura 16C).

Células com fenótipo de interesse nesse estudo ( $\left.\mathrm{CD} 44^{+} / \mathrm{CD} 24^{-}\right)$representaram menos de $0,5 \%$ em células aderentes, assim como nas mamosferas de todas as linhagens avaliadas. No estudo de Vazquez-Martin et al., (2011) essa população era de apenas $0,1 \%$ de mamosferas de $1^{\text {a }}$ geração derivadas da linhagem SKBR3.

Apesar do fenótipo $\mathrm{CD}_{4} 4^{+} / \mathrm{CD} 24^{-}$não estar aumentado em mamosferas, estes resultados estão de acordo com a literatura que mostra que linhagens luminais (MCF-7 e BT474) e HER2+ (SKBR3) são constituídas principalmente por células com baixa expressão de CD44 e alta expressão de CD24 (MUROHASHI et al., 2010; RICARDO et al., 2011).

Foi observado ainda que a segunda população mais abundante dentre células aderentes e de mamosferas das linhagens BT-474 e SKBR3 possuia o fenótipo CD44/CD24- enquanto que nas células MCF-7 aderentes foi a CD44 $4^{+} / \mathrm{CD} 24^{+}$(em concordância com MUROHASHI et al., 2010). O fenótipo $\mathrm{CD}_{4} 4^{-} / \mathrm{CD} 24^{-}$foi o segundo mais frequente em mamosferas derivadas de MCF-7.

A população com fenótipo $\mathrm{CD} 44^{+} / \mathrm{CD} 24^{-/ \text {baixa }}$ que possui características de CSCs de mama, foi primeiramente descrita por Al-Hajj et al. (2003) em tumores de mama primários e é associada com a expressão de marcadores basal/mesenquimal ou mioepiteliais. Todas as linhagens celulares de tumor de mama avaliadas por Sheridan et al., 2009, que mostraram enriquecimento da subpopulação celular $\mathrm{CD}_{4} 4^{+} / \mathrm{CD} 24^{-}$, correspondiam ao subtipo basal e haviam passado pela EMT. Esta mesma observação foi descrita por outros grupos (HONETH et al. 2008; MANI et al., 2008; CHARAFE-JAUFFRET et al., 2009).

\subsubsection{ALDH1 em mamosferas}

Diante dos resultados apresentados acima, que demonstraram a baixa frequência de células com o fenótipo $\mathrm{CD} 44^{+} / \mathrm{CD} 24^{-/ \text {baixa }}$, investigamos na literatura a existência de marcadores de células-tronco que poderiam ser utilizados no isolamento de CSCs de mama. Neste sentido, dois grupos independentes descreveram que o alto nível de expressão da ALDH1 em CSC de mama parecia estar envolvido com características de células com fenótipo HER2+ e basal (NAKSHATRI et al., 2009, RESETKOVA et al., 2010). De modo 
relevante para este trabalho, resultados indicaram que a superexpressão de HER2 em linhagens celulares parece ser suficiente para aumentar a porcentagem e células ALDH+ independente do status de ER (KORKAYA et al., 2008).

Dessa forma, a fim de determinar os percentuais de células $\mathrm{ALDH}^{+}$nas linhagens estudadas e, compará-los entre células aderentes e mamosferas de cada linhagem, foram realizadas análises de citometria de fluxo como mostrado abaixo através de gráficos dot plots representativos (Figura 17). O eixo y corresponde às medidas de dispersão de luz detectadas pelo detector side scatter que capta o feixe de luz disperso pelo fluxo de células de acordo com diferenças de granulosidade. $\mathrm{O}$ eixo $\mathrm{x}$ corresponde a intensidade de fluorescência de BAAA (Aldefluor $\left.{ }^{\circledR}\right)$ captada no canal do fluoróforo FITC-FL1. Os gráficos à esqueda representam os controles negativos (presença do inibidor de BAAA, DEAB).

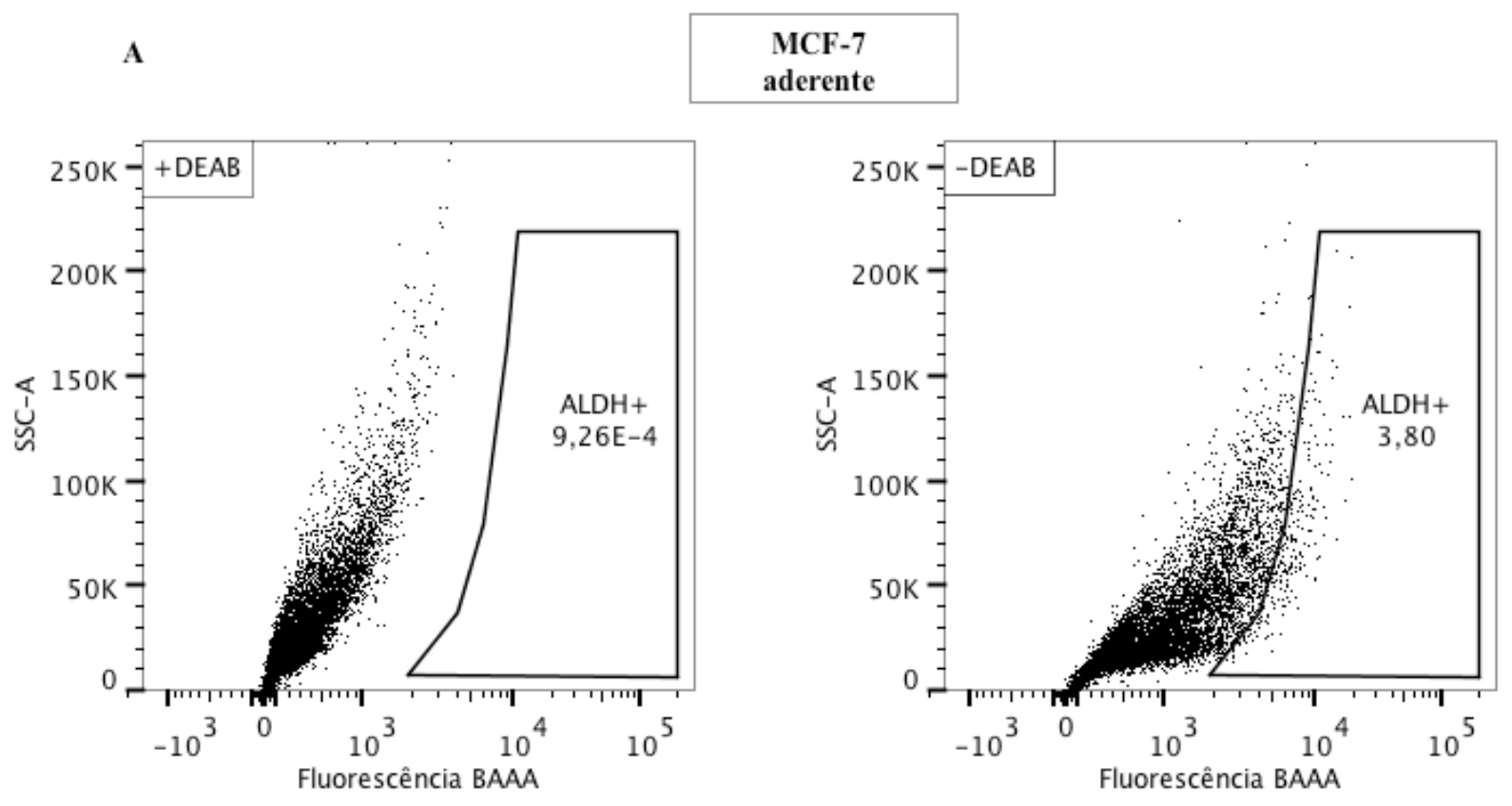



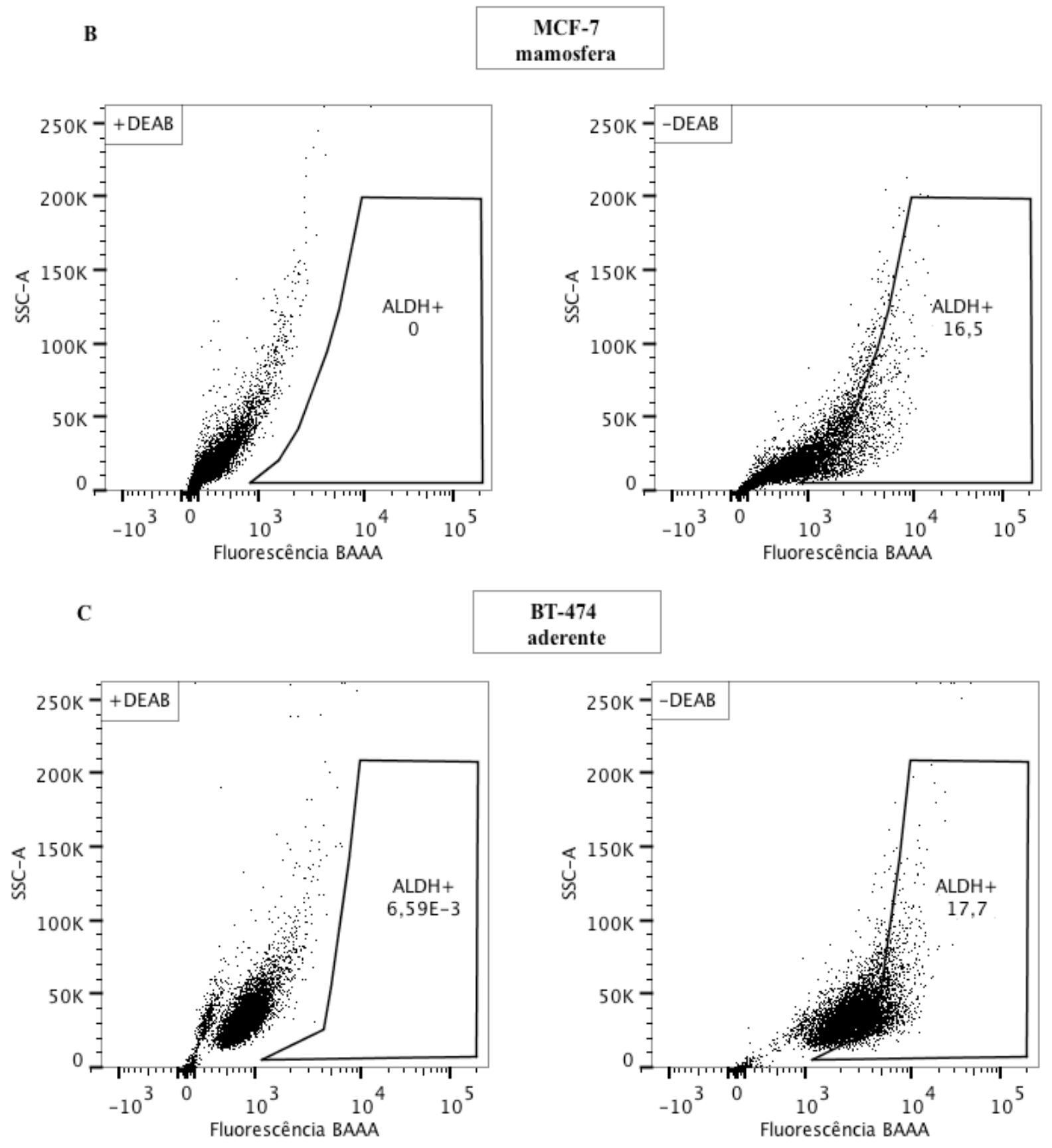
D

BT-474

mamosfera
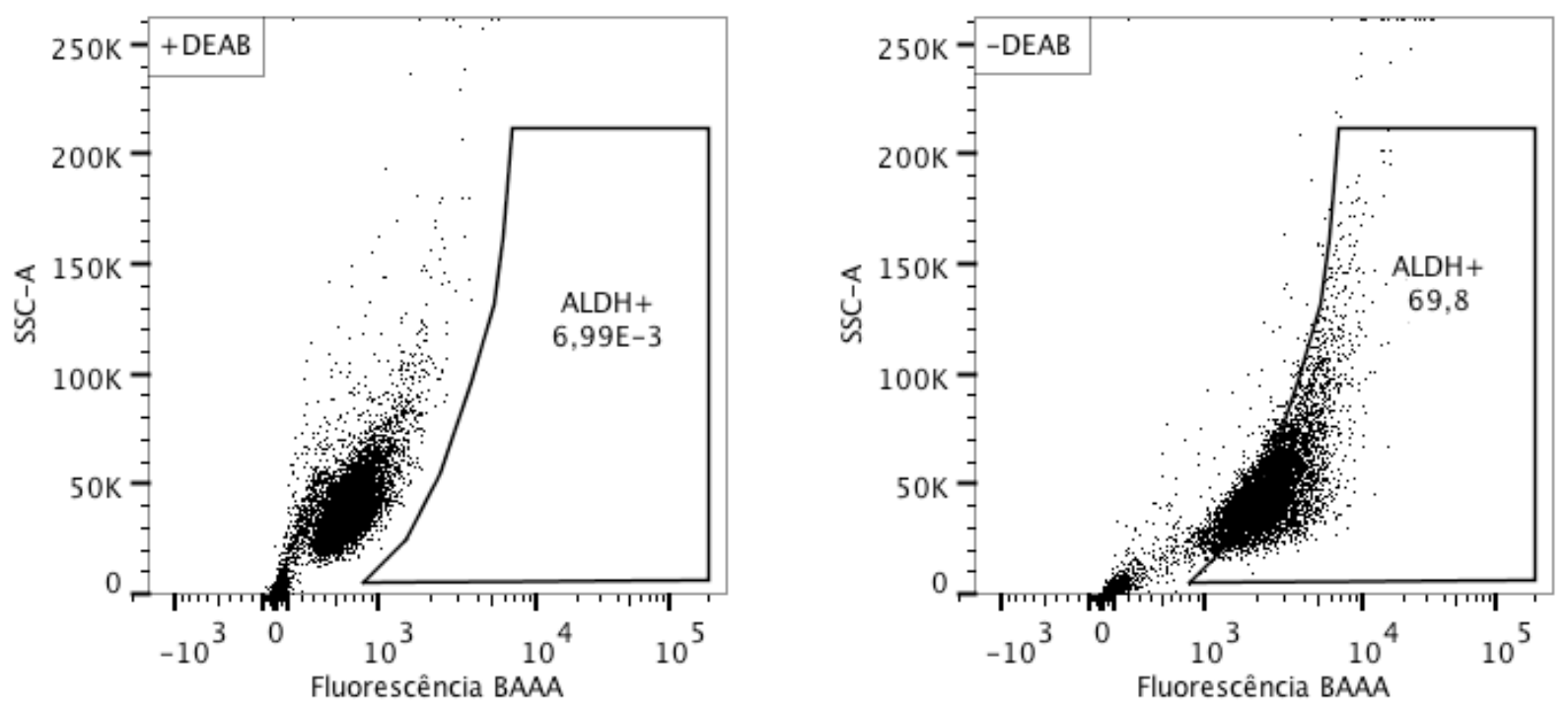

E

SKBR3

aderente
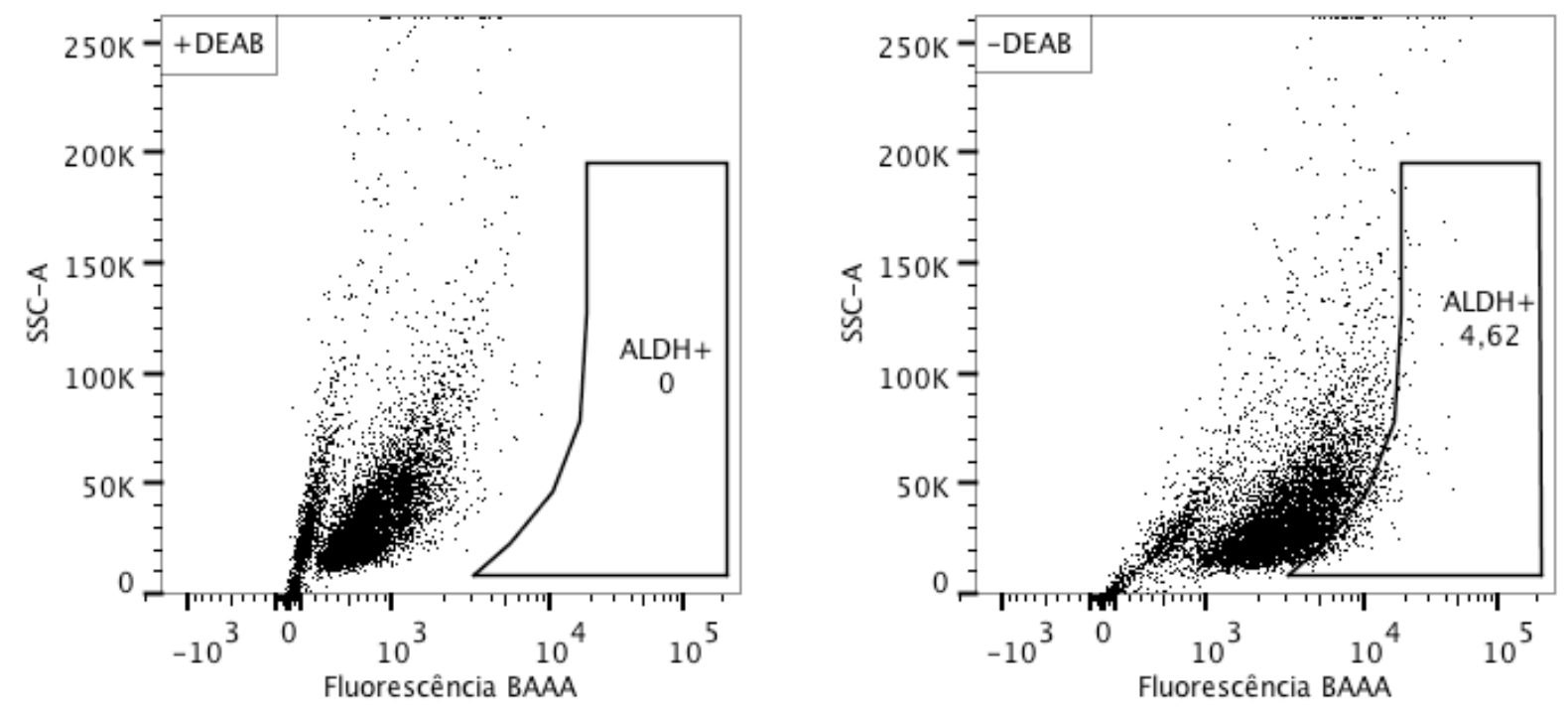


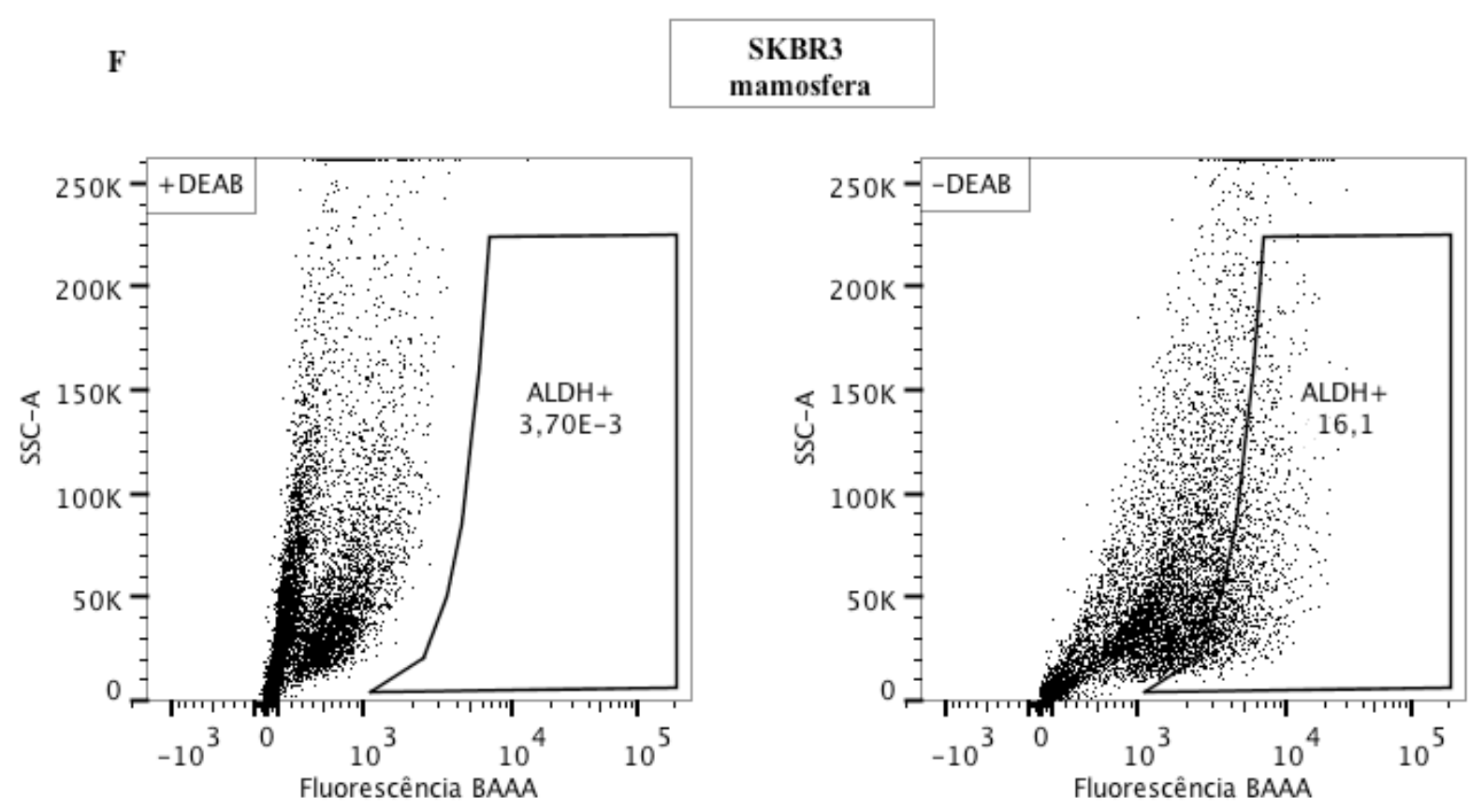

Figura 17 - Dot plots representativos dos percentuais de células $\mathrm{ALDH}^{+}{ }^{+}$entre as células aderentes e derivadas de mamosferas das linhagens MCF-7, BT-474 e SKBR3 na presença ou ausência de DEAB. Percentagens de ALDH1 ${ }^{+}$em células aderentes das linhagens MCF-7 (A), BT-474 (C) e SKBR3 (E) na presença e na ausência de DEAB Percentagens de $\mathrm{ALDH} 1^{+}$em mamosferas de $1^{\text {a }}$ geração das linhagens das respectivas linhagens $(\mathrm{B}, \mathrm{D}$ e F) na presença ou na ausência de DEAB. $O$ eixo y corresponde às medidas de dispersão de luz detectadas pelo detector side scatter que capta o feixe de luz disperso pelo fluxo de células de acordo com diferenças de granulosidade. O eixo $\mathrm{x}$ corresponde à intensidade de fluorescência de BAAA captada no canal do fluoróforo FITC-FL1.

Os gates de seleção (área delimitada), contidos nos gráficos dot plots, determinados através de programa específico, foram todos cuidadosamente analisados e estabelecidos. Nos dot plots representativos dos controles, apesar dos gates de seleção mostrarem valores muito próximos do valor 0 , não continha, absolutamente, nenhum ponto representavivo de célula como mostrado (Figura 17).

Abaixo seguem as análises comparativas dos percentuais de células $\mathrm{ALDH}^{+}$em células aderentes e mamosferas das linhagens estudadas (Figura 18). 


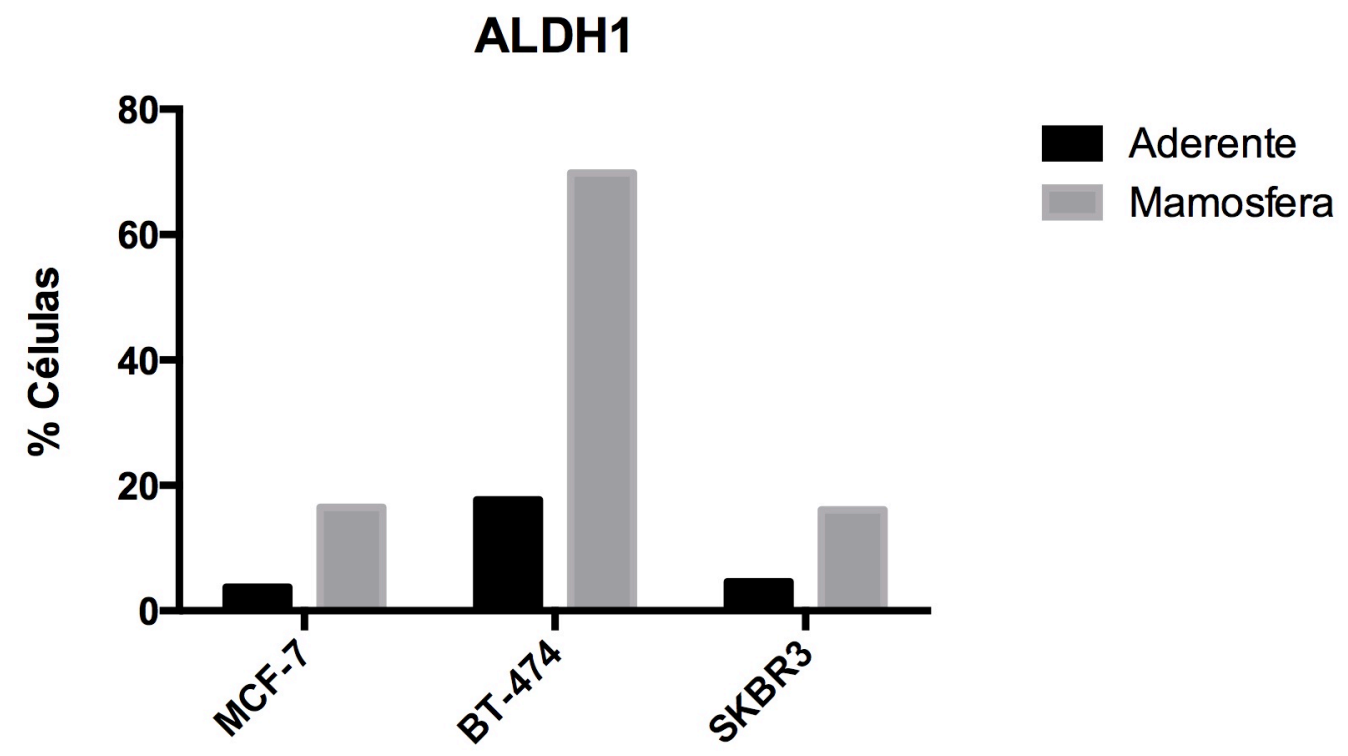

Figura 18 - Percentuais de células $\mathrm{ALDH}^{+}$entre células aderentes e derivadas de mamosferas das linhagens MCF-7, BT-474 e SKBR3.

Atualmente a ALDH1 é considerada o marcador "padrão ouro" para o isolamento de subpopulações de CSC em diversas linhagens tumorais e células derivadas de diversos tipos de tumores tais como: leucemias (ROLLINS-RAVAL et al., 2012), câncer de próstata (LI et al., 2010), carcinoma de nasofaringe (WU et al., 2013), câncer de mama (DE BEÇA et al., 2013; GINESTIER et al., 2007; MORIMOTO et al., 2009), sarcoma (LOHBERGER et al., 2012), câncer colorretal (WANG et al., 2012), câncer renal (OZBEK et al., 2012), câncer de laringe (JIN et al., 2011), câncer gástrico (WAKAMATSU et al., 2012), adenocarcinoma de pulmão (LIANG; SHI, 2012) dentre outros.

Conforme a Figura 18, mostrada acima, os percentuais de células ALDH1 ${ }^{+}$em células aderentes das linhagens MCF-7, BT-474 e SKBR3 foram, respectivamente, 3,8\%, 17,7\% e 4,6\%. Ao mesmo tempo, em células derivadas de mamosferas este percentual foi significantemente maior, atingindo, respectivamente, 16,5\% (aumento de 4,34x), 69,8\% (aumento de 3,94x) e 16,1\% (aumento de 3,5x), nas mesmas linhagens, o que mostra um enriquecimento de células $\mathrm{ALDH}^{+}$em cultura de mamosferas obtidas a partir de todas as linhagens aqui estudadas.

Com estes percentuais de células $\mathrm{ALDH}^{+}$, abriu-se a possibilidade de isolá-las a partir de culturas aderentes tanto wt quanto após a indução de superexpressão dos miRNAs que foram realizados nos experimentos subsequentes deste trabalho. 
3.3.2.5 Expressão endógena de HER2 em células aderentes e mamosferas

Primeiramente foram realizadas análises comparativas da expressão endógena de HER2 nas linhagens estudadas em condições aderentes (Figura 19). Apesar dos níveis de expressão de HER2 estarem bem estabelecidos nas linhagens MCF-7, BT-474 e SKBR3, essa análise comparativa foi realizada a fim de confirmar esse perfil e permitir análises de correlação com os miRNAs estudados (etapa subsequente).

\section{HER2}

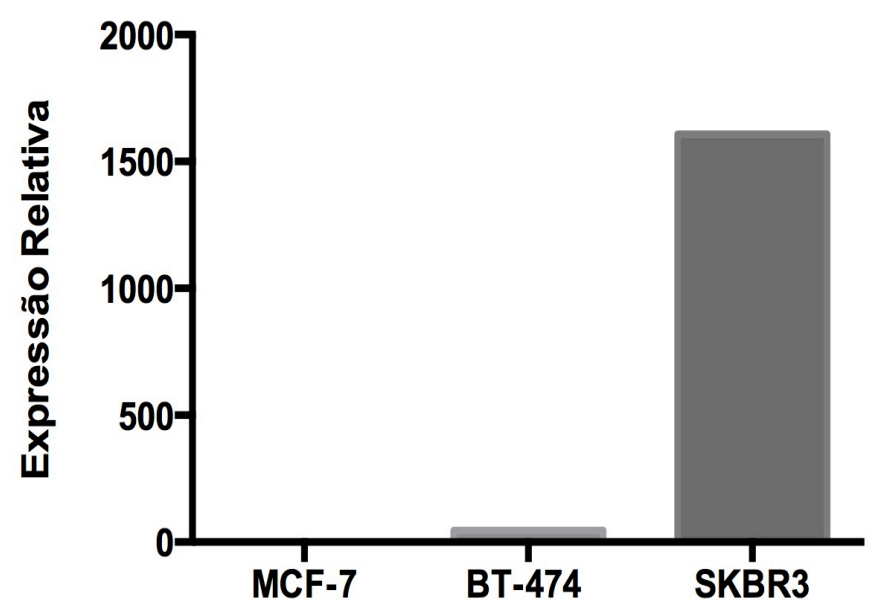

Figura 19 - Expressão endógena de HER2 nas células wild-type aderentes das linhagens MCF-7, BT474 e SKBR3.

De acordo com o esperado, as células BT-474 e SKBR3 apresentaram expressões endógenas de $H E R 2$, respectivamente, 45x e 1600x maiores comparadas com células MCF-7.

Após a análise da expressão de HER2 entre as linhagens MCF-7, BT-474 e SKBR3, foram realizadas análises da expressão endógena de $H E R 2$ entre células aderentes e derivadas de mamosferas de quatro gerações (M7, M14, M21 e M28) (Figura 20). 
HER2

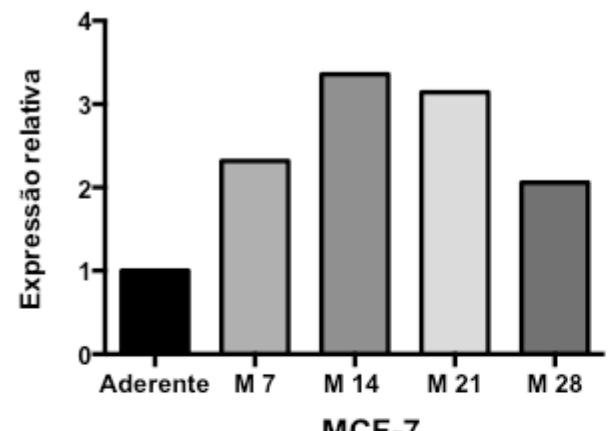

MCF-7
HER2

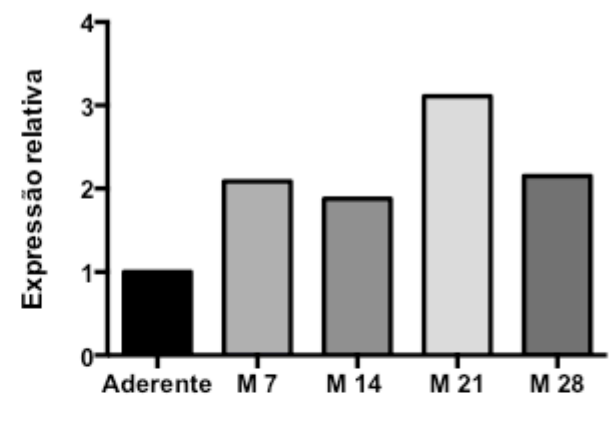

SKBR3

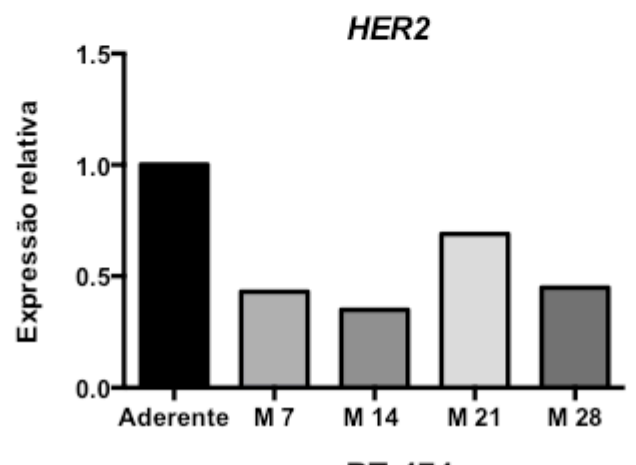

Figura 20 - Análise da expressão endógena relativa de $H E R 2$ em células aderentes e derivadas de mamosferas das linhagens MCF-7, BT-474 e SKBR3. Mamosferas de 7 (M7), 14 (M14), 21 (M21) e 28 dias (M28) das linhagens MCF-7(A), BT-474 (B) e SKBR3 (C).

Alguns grupos reportaram a importância da sinalização de $H E R 2$ na manutenção de células-tronco tumorais de mama (KORKAYA et al., 2008; LI et al., 2008, MAGNIFICO et al., 2009).

Na Figura 20 acima, foi observado um aumento da expressão de $H E R 2$ ( $>2 \mathrm{x}$, em sua grande maioria) em mamosferas das linhagens MCF-7 e SKBR3, quando comparados com as células aderentes dessas linhagens (Figura 20). Este efeito não foi observado em BT-474 que ao contrário, apresentou níveis diminuídos de HER2.

De grande relevância para o gerenciamento clínico de pacientes com tumores de mama, alguns autores relataram o sucesso terapêutico do tratamento com tzb de tumores primários de mama HER2-. Um destes trabalhos avaliou a efetividade de tzb no tratamento de pacientes com amplificação de HER2 e observaram que 174 pacientes originalmente classificados como HER2+ eram na verdade HER- e tiveram uma resposta ao tzb similar a pacientes com amplificação de HER2 (PAIK; KIM; WOLMARK, 2008). A confiabilidade deste estudo foi inicialmente questionada, no entanto resultados similares também foram posteriormente reportados por outro grupo (PEREZ et al., 2010). 
Em Março de 2013 o grupo do Dr. Max Wisha publicou um trabalho seminal mostrando que Her2 é seletivamente expresso e regula a auto-renovação de CSC de tumores luminais ER+ e Her2- (ITHIMAKIN et al., 2013). Os resultados deste trabalho foram gerados a partir de linhagens celulares de câncer de mama, em modelos animais e em tumores humanos primários e metastáticos pareados. Surpreendentemente a expressão de HER2 nos tumores luminais primários HER2- se mostrou aumentada nos ossos de camundongos xenotransplantados, assim como em metástases de pacientes, quando comparados com os tumores primários. Em ensaios in vitro células da linhagem MCF-7 que expressavam HER2 possuíam uma capacidade de gerar tumores muito maior do que células HER2-. Os achados deste paper corroboram um outro trabalho que mostrou que $89 \%$ das mulheres com tumores de mama HER2- possuíam células tumorais circulantes HER2+ (GEORGOULIAS et al., 2012).

O aumento de expressão de HER2 não se deu pela amplificação gênica do oncogene, mas sim pela ligação de RANK (produzido no microambiente ósseo por osteoblastos) ao seu receptor expresso nas CSCs de mama, que por sua vez ativa NF-kB e leva a expressão de HER2 (ITHIMAKIN et al., 2013).

Os dados gerados neste trabalho são tão importantes que um ensaio clínico randomizado está atualmente sendo conduzido pelo National Surgical Adjuvant Breast and Bowel Project (NSABP, Protocolo B47), buscando avaliar os benefícios clínicos da administração de tzb em mulhers com câncer de mama com HER2-1 ${ }^{+}$e HER2-2 ${ }^{+}$ determinados por imunohistoquímica e sem amplificação gênica de HER2.

\subsubsection{Expressão dos miRNAs -221, -222 e -4728-3p em células aderentes e mamosferas}

A seguir, foi realizada uma análise comparativa da expressão endógena de miR-221, 222 e -4728-3p entre as linhagens MCF-7, BT-474 e SKBR3 (Figura 21). 


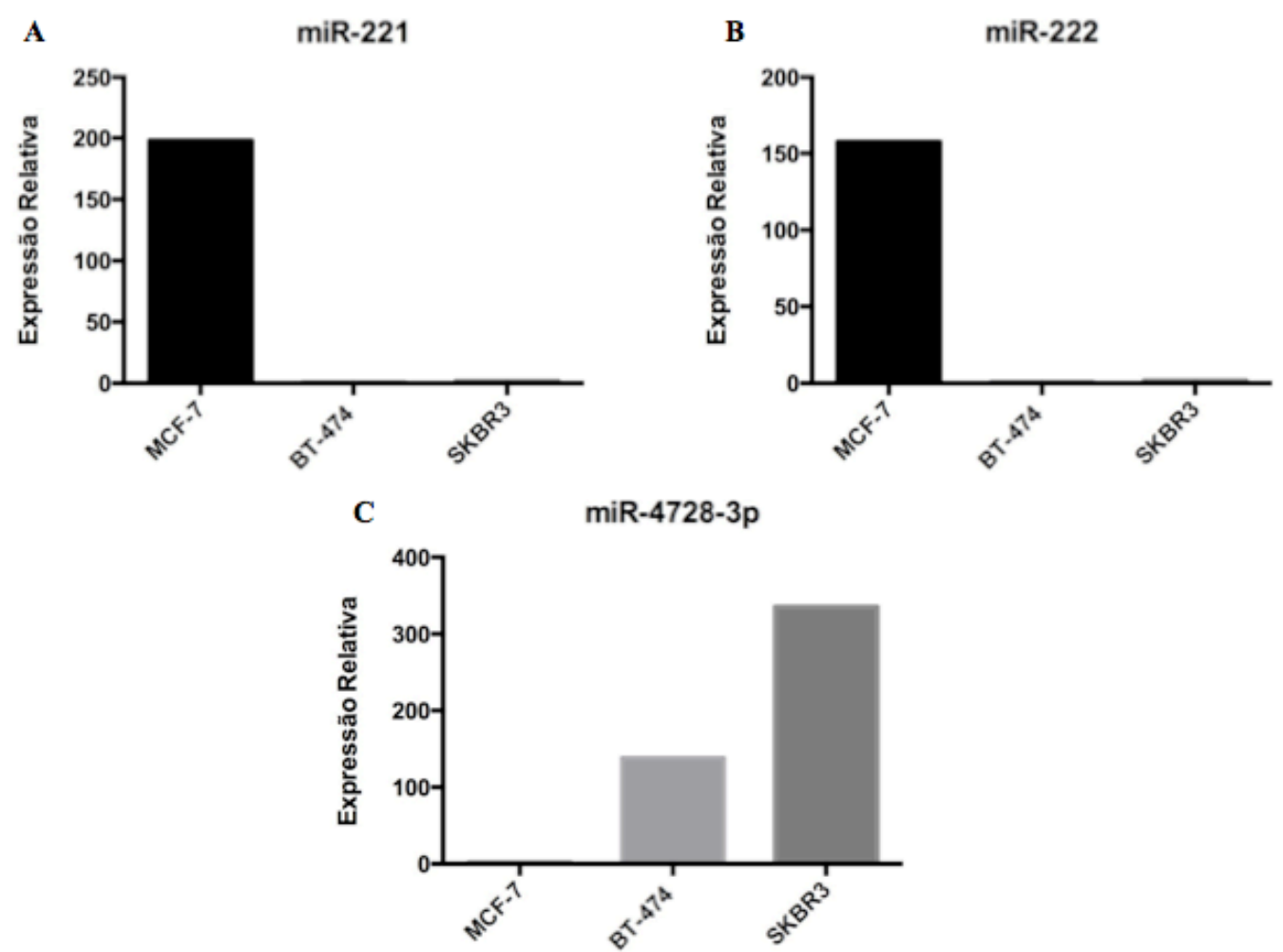

Figura 21 - Expressão endógena relativa de miR-221, -222 e -4728-3p nas células wild-type aderentes das linhagens MCF-7, BT-474 e SKBR3.

Foi observado que células MCF-7 possuem a maior expressão de miR-221 e -222 entre as linhagens estudadas, apresentando, respectivamente, 198x e 157x mais que células BT-474, que possui a menor expressão desses miRNAs nessas linhagens.

Células SKBR3 possuem expressão de ambos miRNAs 2x maior que células BT-474. Estes resultados estão de acordo com Sempere et al. (2007) que avaliou a expressão desses miRNAs nas mesmas linhagens e verificou que estavam aumentados em células MCF-7 quando comparadas com células BT-474 e SKBR3.

A análise da expressão do miRNA-4728-3p, mostrou que este se encontrava 138x mais expresso na BT-474 e 335x mais na SKBR3 ambas comparadas com células MCF-7, a qual apresentou a menor expressão desse miRNA. Este resultado está de acordo com Persson et al. (2011), que também verificou a expressão desse miRNA nessas mesmas linhagens e observou que células que possuem superexpressão de HER2 também apresentam níveis aumentados de 4728-3p conforme exposto no início deste trabalho.

A seguir a expressão endógena dos miRNAs -221, -222 e -4728-3p foi analisada nas linhagens MCF-7, SKBR3 e BT-474, tanto em cultura de células aderentes quanto em mamosferas. 
A expressão relativa dos miRNAs nas mamosferas foi calculada em relação à expressão dos mesmos em células aderentes. Nestes experimentos, os quais foram realizados anteriormente à transdução viral, avaliou-se a expressão dos miRNAs de interesse em diferentes em mamosferas de quatro gerações (M7, M14, M21 e M28), a fim de confirmar se nestas condições estes miRNAs seriam induzidos, e qual seria o time-point de maior indução.

Todos os dados obtidos para todas as linhagens celulares e para todos os miRNAs são mostrados a seguir na Figura 22.

MCF-7
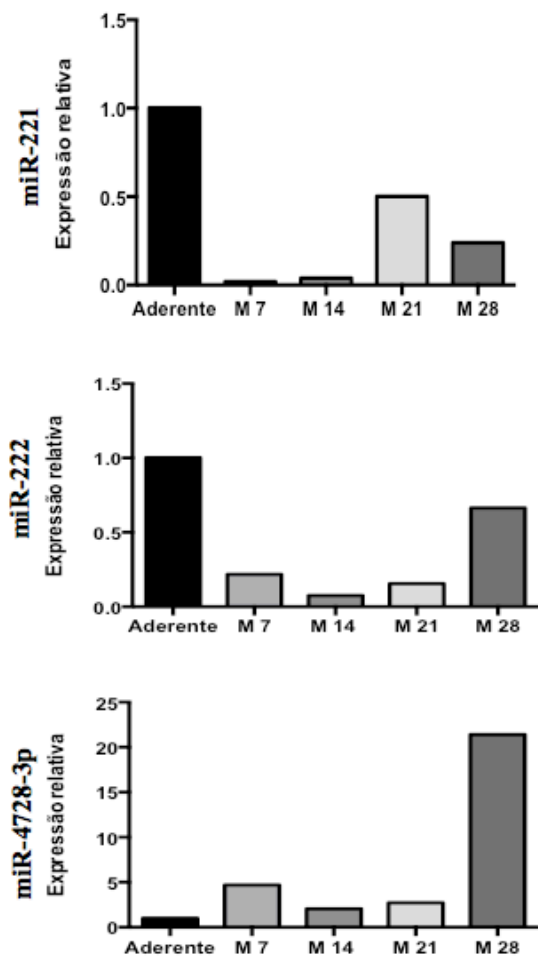

SKBR3
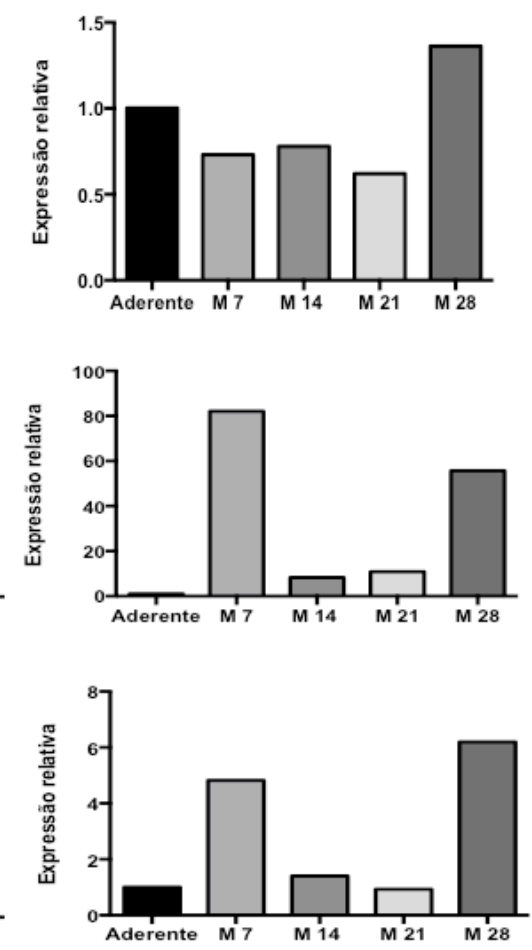

BT-474
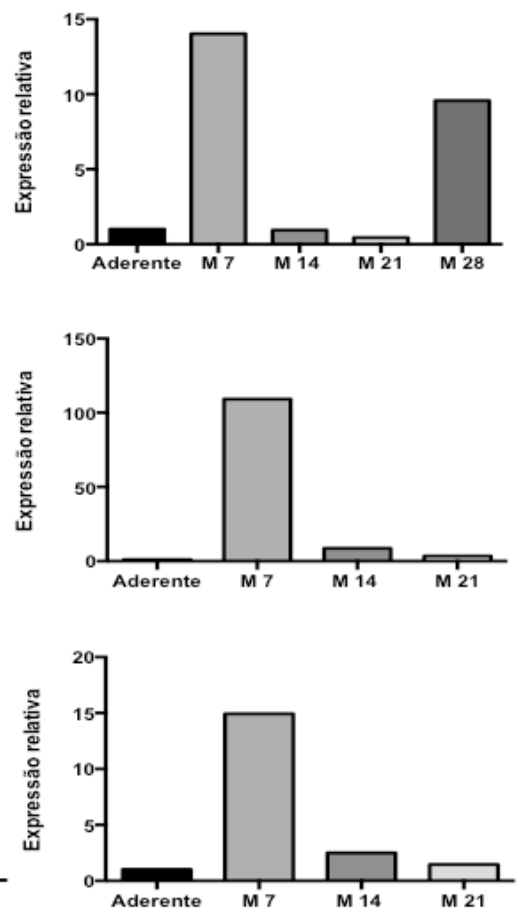

Figura 22 - Análise da expressão endógena relativa de miR-221, -222 e -4728-3p em células aderentes e derivadas de mamosferas das linhagens celulares MCF-7, BT-474 e SKBR3. Mamosferas de 7 (M7), 14 (M14), 21 (M21) e 28 dias (M28) de cultivo.

Para a linhagem MCF-7, foi observado um aumento de expressão apenas do miRNA4728-3p nas mamosferas em relação à expressão em condições aderentes, com pico de expressão em M28 (21x).

Em relação à linhagem SKBR3, foi observada uma expressão mais elevada de todos os miRNAs do estudo nas mamosferas em relação às células aderentes em pelo menos uma das gerações de mamosferas. O miRNA-221 se mostrou ligeiramente aumentado em M28 (1.4x), enquanto que o miRNA-222 teve seu pico em M7 (82x), e o miR-4728-3p apresentou um picoo em M28 (6.2x). 
Já na linhagem BT-474, os picos de expressão de todos os miRNAs foram observados na mesma geração: M7 (variando de 14x a 109x), e também foi observada uma elevação da expressão do miRNA-221 na geração M28.

O perfil de expressão dos miRNAs -221 e -222 foram diferentes entre si nas mesmas linhagens. Apesar desses miRNAs serem co-expressos e possuírem a mesma seed-sequence, eles possuem diferenças nas suas sequências downstream à seed-sequence (BAEK et al., 2008), como foi discutido no Capítulo I, o que pode indicar que eles possam ser regulados por diferentes moléculas ou mecanismos.

\subsubsection{Superexpressão dos miRNAs em linhagens utilizando construtos lentivirais.}

\subsubsection{Determinação da proporção dos plasmídeos na co-transfecção}

Para a produção de vetores lentivirais baseados no HIV foi necessária a co-transfecção de três plasmídeos necessários à formação da partícula viral), além do plasmídeo de interesse que codifica o gene para a superexpressão do miRNA e um gene-repórter RFP (Red Fluorescence Protein) (vetores: CD516B-scramble; CD516B-mir-221; CD516B-mir-222 e CD516B-mir-4728-3p), conforme descrito nos Materiais e Métodos deste Capítulo. Portanto, foi necessária a determinação da proporção dos plasmídeos de interesse e da mistura dos 3 plasmídeos de formação da partícula viral ( $p P A C K H 1)$. Para isso, foi empregado o plasmídeo utilizado como controle positivo, pSIH1-H1-siLuc-copGFP, presente no kit adquirido.

Inicialmente, foram testadas relações de plasmídeo controle positivo : $p P A C K H 1$ nas proporções 1:6 e 1:4. Os resultados foram avaliados por microscopia de fluorescência capturadas em $48 \mathrm{~h}$ após a co-transfecção. Imagens fotográficas registrando estes resultados (em luz visível e em fluorescência) são apresentadas a segir (Figura 23). 


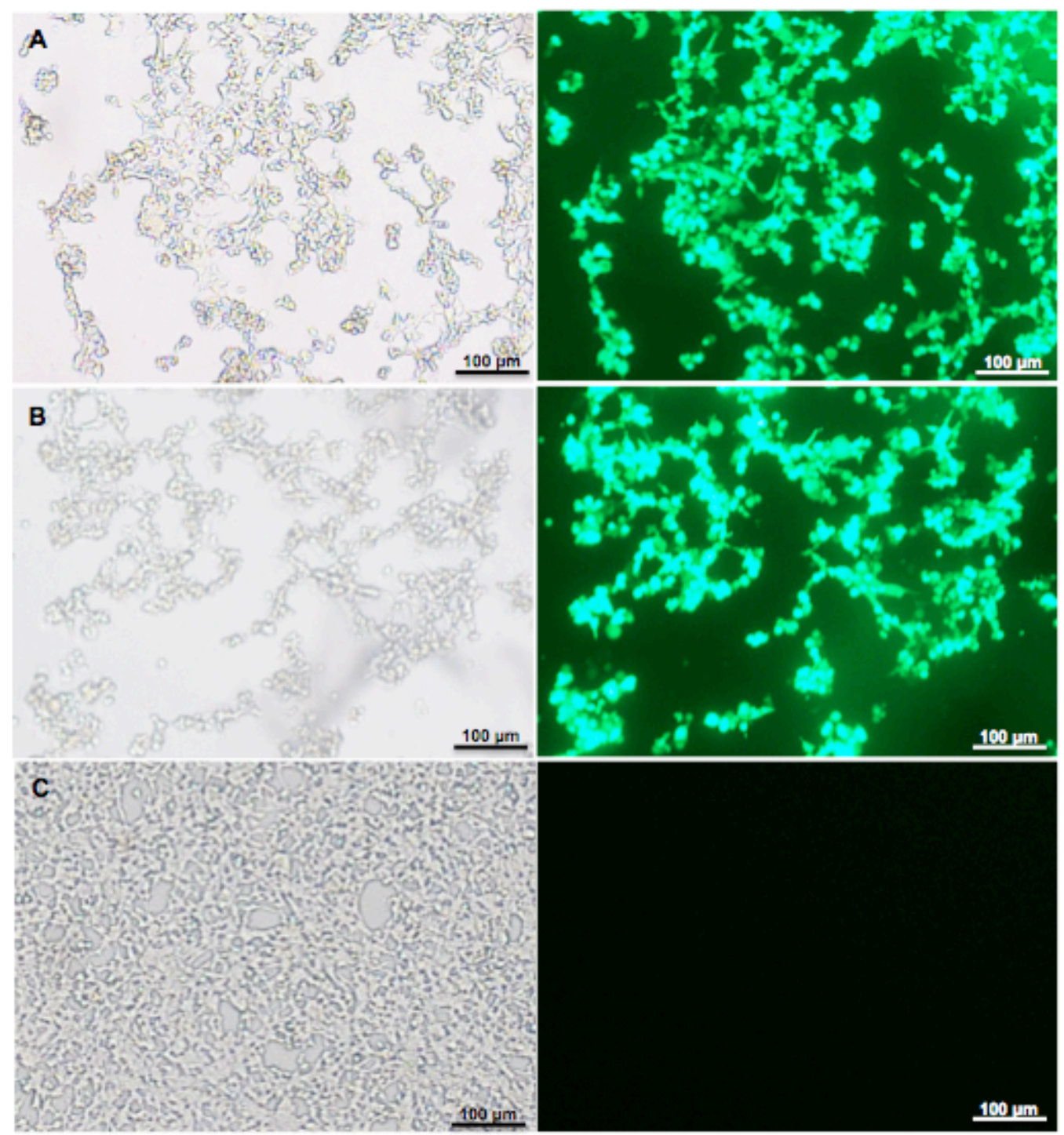

Figura 23 - Imagens fotográficas por microscopia em luz visível e UV da linhagem celular 293T/17 48h após a co-transfecção do plasmídeo controle positivo pSIH1-H1-siLuc-copGFP : pPACKH1 em diferentes proporções. (A) 1:6 (B) 1:4 (C) Controle negativo.

Os resultados indicaram maior intensidade de fluorescência em células cotransfectadas na proporção 1:4 em 48h após a co-transfecção. A partir de $24 \mathrm{~h}$ após a cotransfecção foram observadas alterações na morfologia celular para um aspecto arredondado, além da presença de sincício, que é resultado indicador de fusão celular resultante de replicação viral, efeitos observados nas duas proporções de plasmídeos testadas.

A fim de verificar o efeito da co-transfecção dos plasmídeos e, posteriormente, o efeito da transdução dos mesmos nas células de interesse, foram realizadas co-transfecções com o plasmídeo CD516B-mir-222, o qual possui maior tamanho em relação aos demais plasmídeos de interesse, inclusive em relação ao plasmídeo controle positivo pSIH1-H1siLuc-copGFP. 
A partir desse experimento, observou-se, além da expressão de RFP, alteração da morfologia celular com a presença de sincícios e grande desprendimento de células 293T/17, principalmente $72 \mathrm{~h}$ após a co-transfecção (tempo no qual coletou-se o sobrenadante para a transdução viral nas células de interesse). A transdução nas células-alvo, não ocorreu após ser usado o protocolo original da empresa SBI. Portanto, houve a necessidade de padronização da técnica.

A fim de evitar o desprendimento de células 293T/17 e determinar qual o tempo do ponte de coleta com maior número de partículas virais viáveis, co-transfecções foram testadas na presença ou ausência de poli-lisina, além de duas diferentes proporções de plasmídeos (CD516B-mir-222: pPACKH1, 1:2 e 1:4) e diferentes tempos de coleta (24, 48 e 72h), conforme Figura 24.

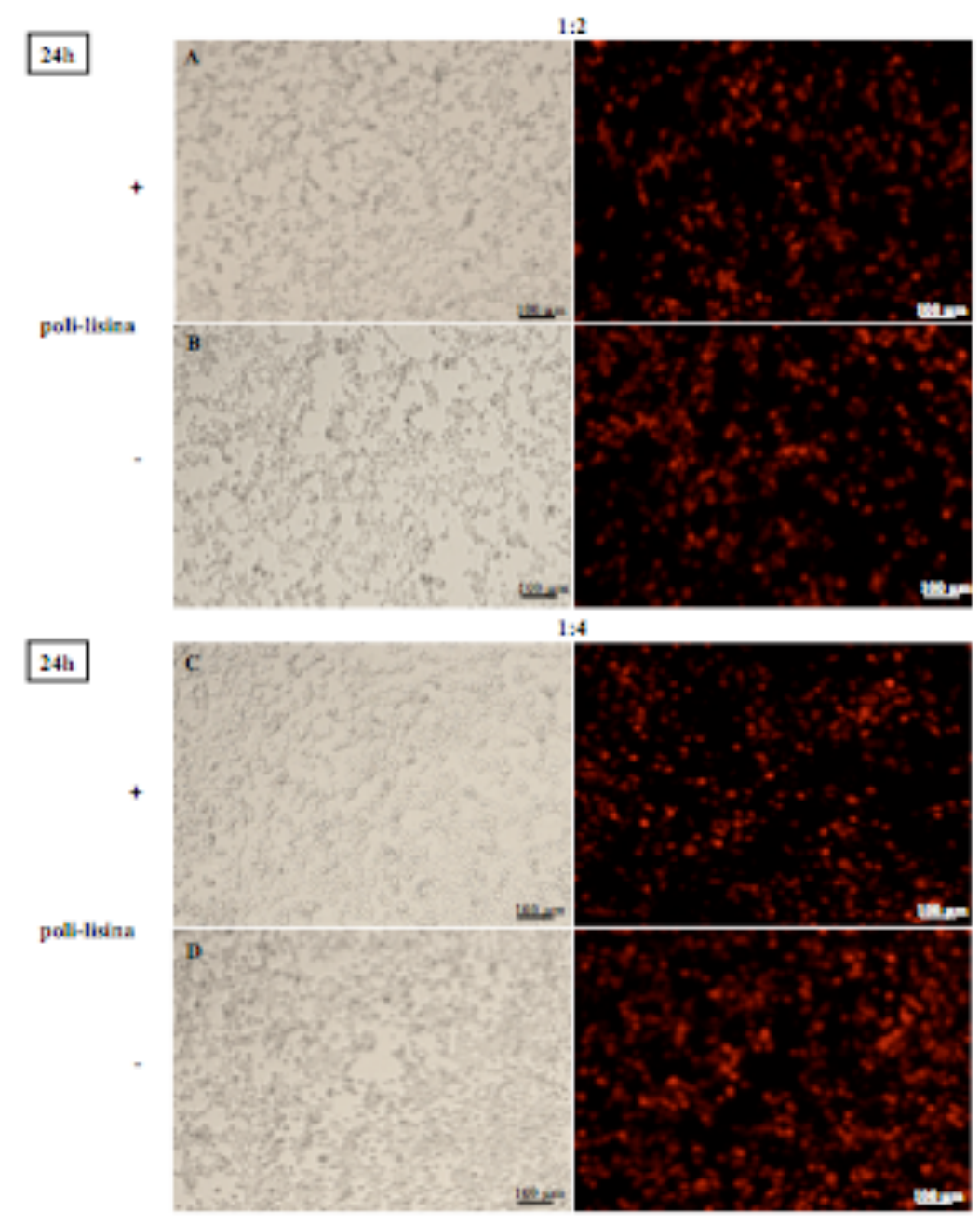




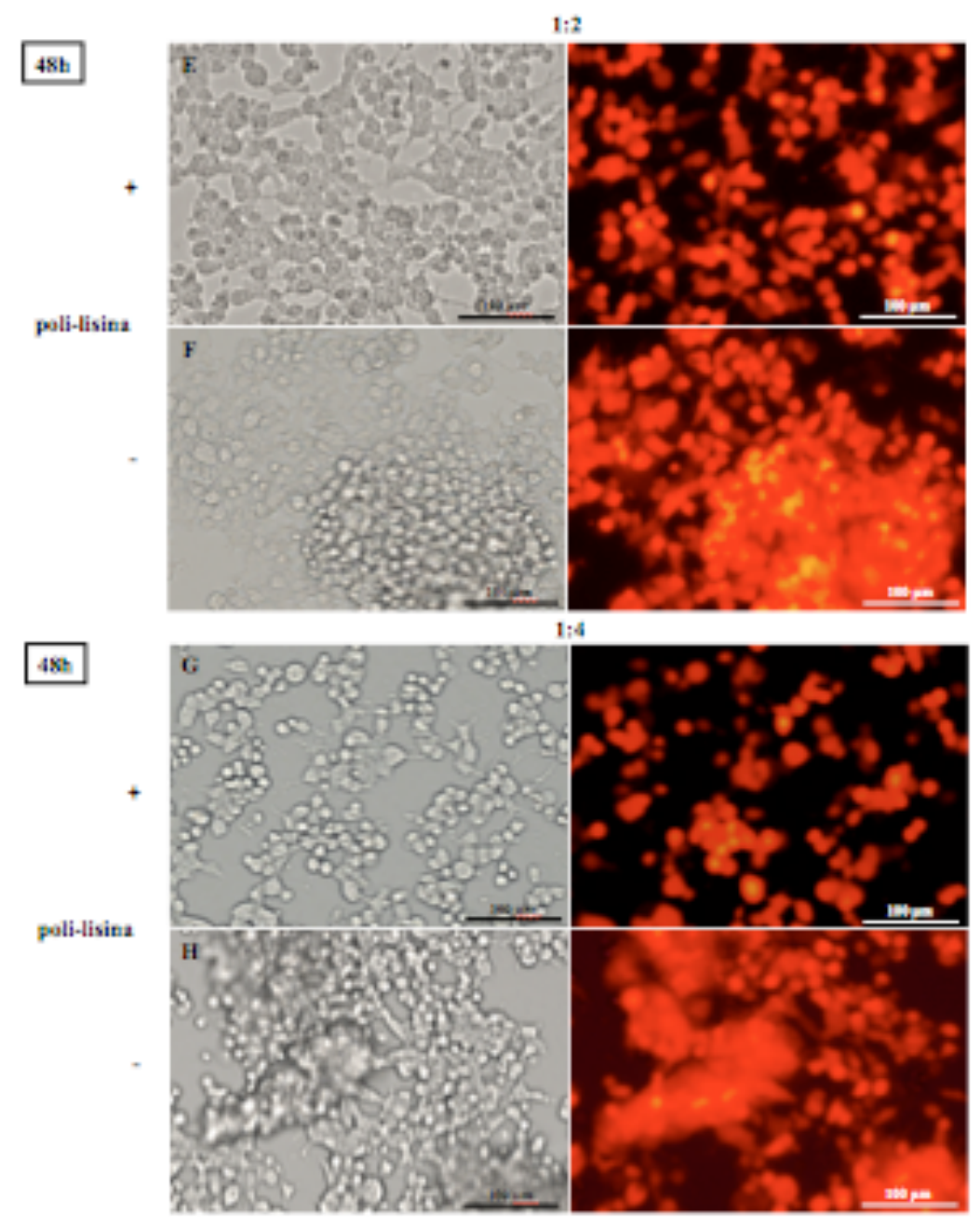




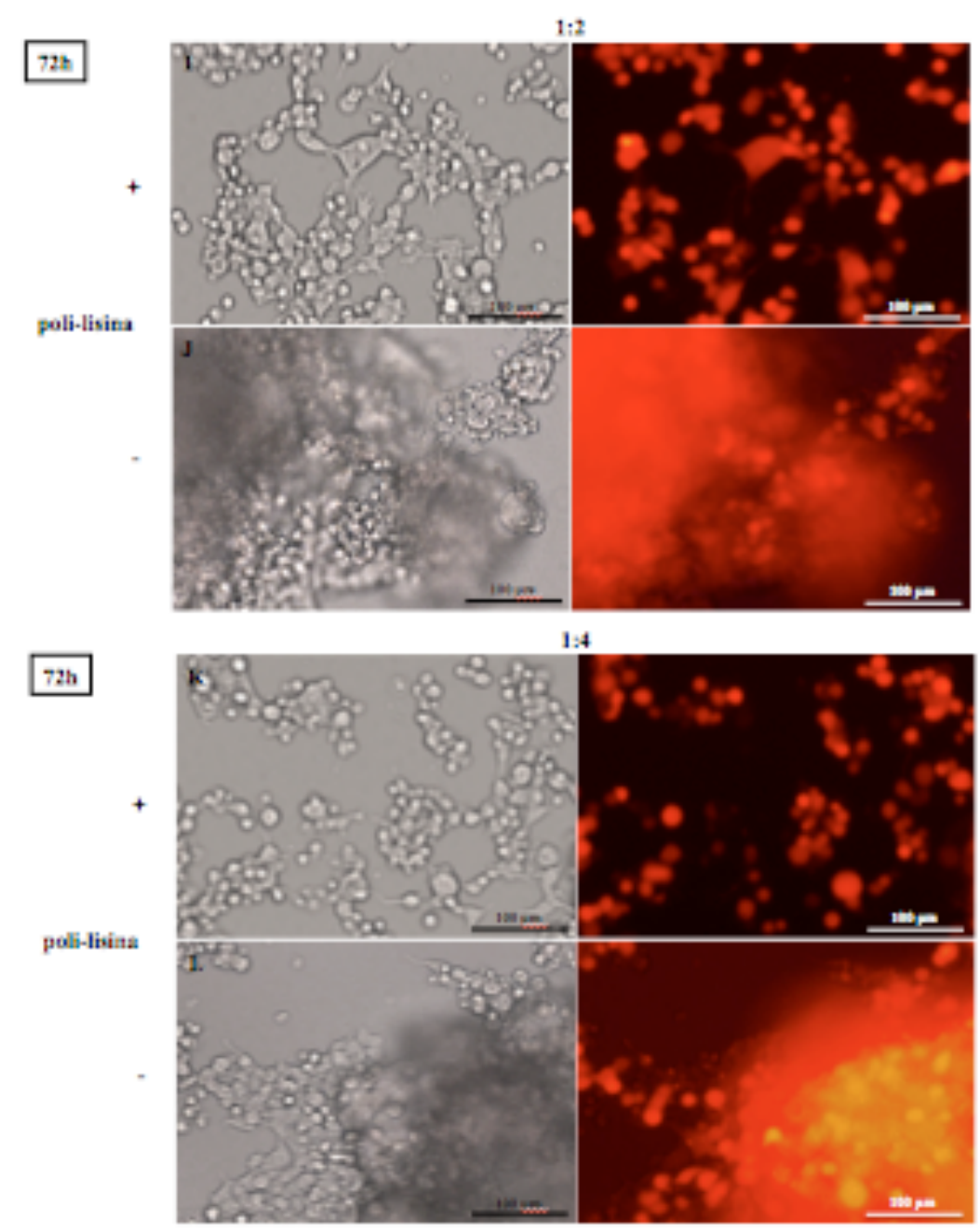

Figura 24 - Imagens fotográficas por microscopia em luz visível e UV da linhagem celular 293T/17 após a co-transfecção dos plasmídeos CD516B-mir-222 : pPACKH1 em diferentes proporções, na ausência ou presença de poli-lisina em diferentes tempos. Presença de poli-lisina (A, C, E, G, I, K) ou ausência $(\mathbf{B}, \mathbf{D}, \mathbf{F}, \mathbf{H}, \mathbf{J}, \mathbf{L})$. Fotografia foram feitas $24 \mathrm{~h}$ (A-D) $48 \mathrm{~h}(\mathbf{E}-\mathbf{H})$ ou $72 \mathrm{~h}$ (I-L) após a tranfecção. As proporções usadas dos plasmídeos CD516B-mir-222 : pPACKH1 foram 1:2 (A-B, E-F, I-J) ou 1:4 (C-D, G-H, K-L).

A partir desses resultados mostrados acima (Figura 24), foi possível observar que a presença da poli-lisina evitou o grande desprendimento de células, principalmente nos pontos de 48 e 72h após a co-transfecção. As proporções 1:2 e 1:4 entre plasmídeos CD516B-mir222 : pPACKH1 não apresentaram diferenças aparentes, porém os tempos de 24,48 e $72 \mathrm{~h}$ apresentaram diferenças significativas em relação ao desprendimento e morte celular. Portanto, a fim de verificar a influência dos diferentes tempo de coleta do sobrenadante no título viral, a etapa de determinação da titulação viral foi realizada. 


\subsubsection{Titulação viral}

As titulações virais foram feitas por qRT-PCR utilizando o kit UltraRapid Lentiviral Titer (SBI), que contém um iniciador universal (WPRE) para qualquer construto baseado em HIV proveniente da SBI e um outro iniciador universal (UCR1) utilizado como uma referência interna para o cálculo do MOI.

Para determinar os MOIs das amostras foram utilizados gDNAs derivados de células 293T/17 transduzidas com sobrenadantes contendo partículas virais coletadas 24, 48 e $72 \mathrm{~h}$ após a infecção. Os pontos da curva de calibração foram amplificados simultaneamente com as nossas amostras. A curva de calibração (Figura 25) mostra a correlação entre os valores de MOI das amostras fornecidas pelo fabricante e os valores $2^{-\Delta \mathrm{CT}}$ de cada amostra obtidos na reação, onde $\Delta \mathrm{Ct}=\mathrm{Ct}$ WPRE $-\mathrm{Ct}_{\mathrm{UCR} 1}$. Para determinar o valor de MOI e, posteriormente o número de partículas virais presentes nos sobrenadantes analisados, foi utilizada a equação da reta $(\mathrm{y}=\mathrm{ax}+\mathrm{b})$ obtida a partir curva de calibração, onde y é o valor de MOI a ser determinado para cada amostra e $\mathbf{x}$ o valor dado por $2^{-\mathrm{ACT}}$ de cada amostra analisada $(\mathrm{y}=$ 0,4075 multiplicado pelo valor de $2^{-\Delta \mathrm{CT}}$ ). A partir da determinação dos valores de MOI dos sobrenadantes foi possível determinar a concentração de partículas virais (IFU/mL) presentes nos sobrenadantes através da seguinte equação: $\left(\mathrm{MOI}_{\text {amostra }}\right)$ x (número de células utilizados no momento da transdução) x 1000/ $\mu 1$ de sobrenadante contendo partículas virais para a transdução. As concentrações de partículas virais obtidas nos sobrenadantes de 24, 48 e $72 \mathrm{~h}$ foram, respectivamente, $8.71 \times 10^{6}, 12.6 \times 10^{6}$ e $0.136 \times 10^{6} \mathrm{IFU} / \mathrm{mL}$.

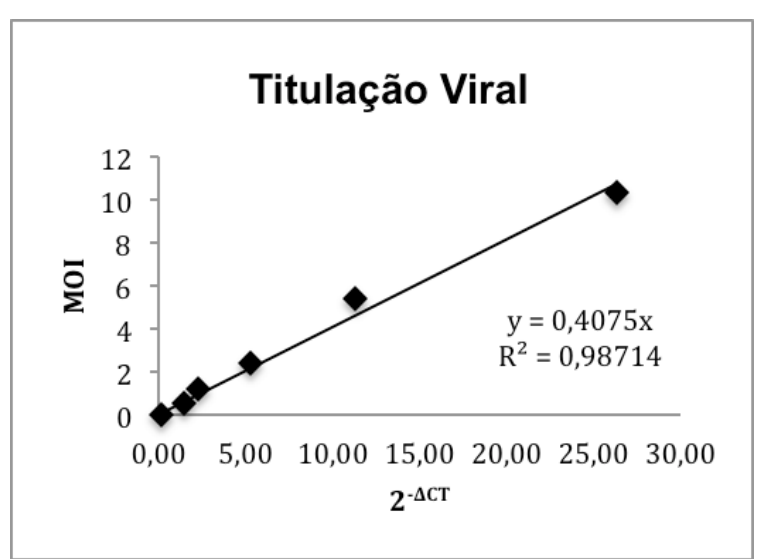

Figura 25 - Curva de calibração para titulação viral. No eixo x: valores de $2^{-\Delta C T}$ e no eixo y: valores de MOI, equação da reta $(\mathrm{y}=0,4075 \mathrm{x})$ e $\mathrm{R}^{2}$ (coeficiente de correlação). Da esquerda para a direita temos: ponto 1 (MOI $0 ; 2^{-\Delta \mathrm{CT}}: 0,16$ ), ponto 2 (MOI $0.52 ; 2^{-\Delta \mathrm{CT}}: 1,46$ ), ponto 3 (MOI $1.22 ; 2^{-\Delta \mathrm{CT}}: 2,22$ ), ponto 4 (MOI 2.4; $2^{-\Delta \mathrm{CT}}: 5,23$ ), ponto 5 (MOI $5.4 ; 2^{-\Delta \mathrm{CT}}: 11,27$ ) e ponto 6 (MOI $10.3 ; 2^{-\Delta \mathrm{CT}}: 26,30$ ). 


\subsubsection{Transdução viral nas células-alvo}

Para a transdução das partículas virais nas células-alvo foram utilizados diferentes volumes $(10,20,50$ e $100 \mu \mathrm{L})$ de sobrenadante do ponto de coleta de $48 \mathrm{~h}$ após a cotransfecção, uma vez que este apresentou maior concentração de partículas virais. Além disso, o sobrenadante deste mesmo ponto mostrou maior expressão do gene-repórter (RFP) sem sinais de morte celular (Figura 26). As linhagens MCF-7, SKBR3 e BT-474 foram transduzidas com $10 \mu \mathrm{L}$ de sobrenadante contendo lentivetores para a superexpressão de miR221, -222 e -4728-3p e co-expressão o gene-repórter RFP (Figura 26). 


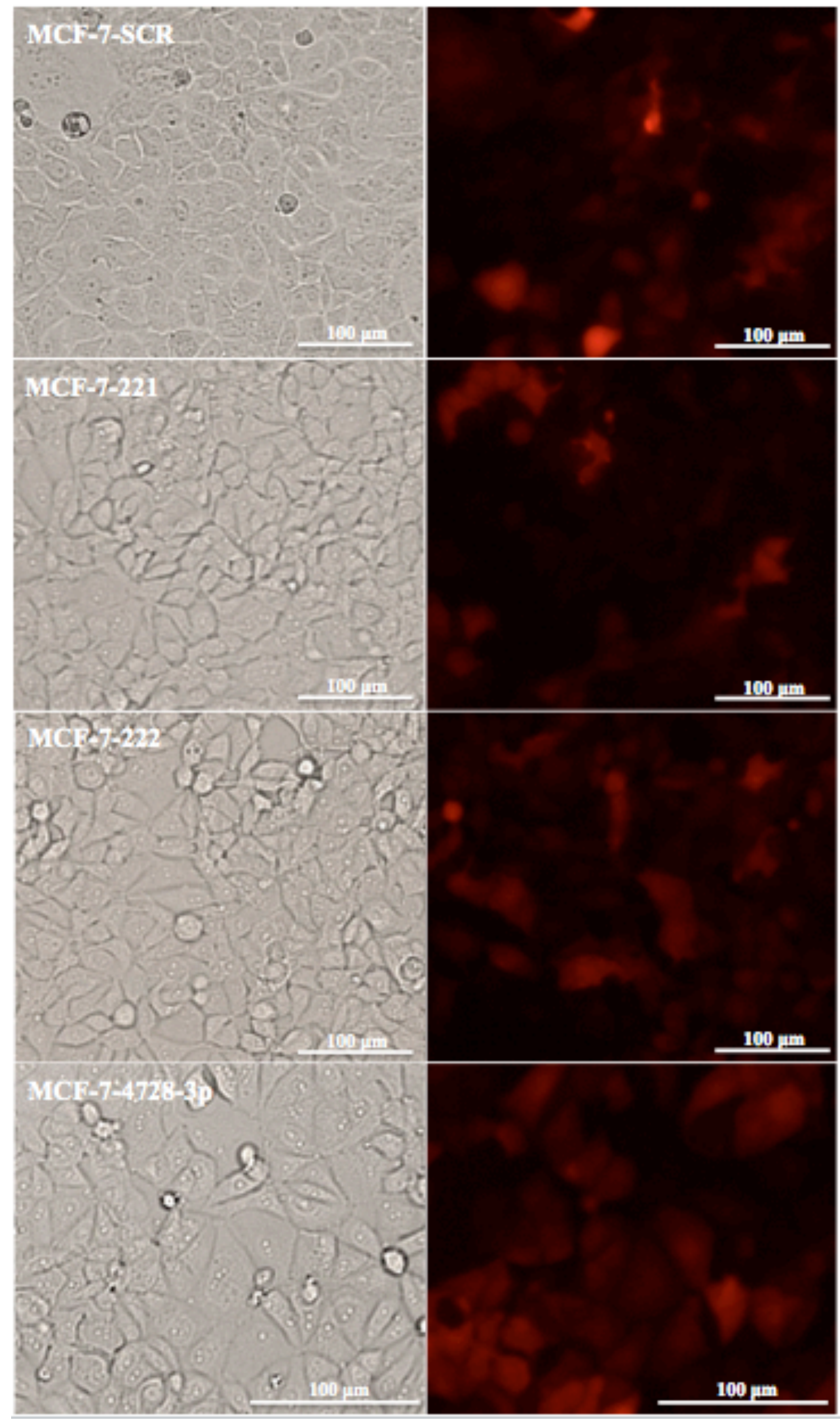




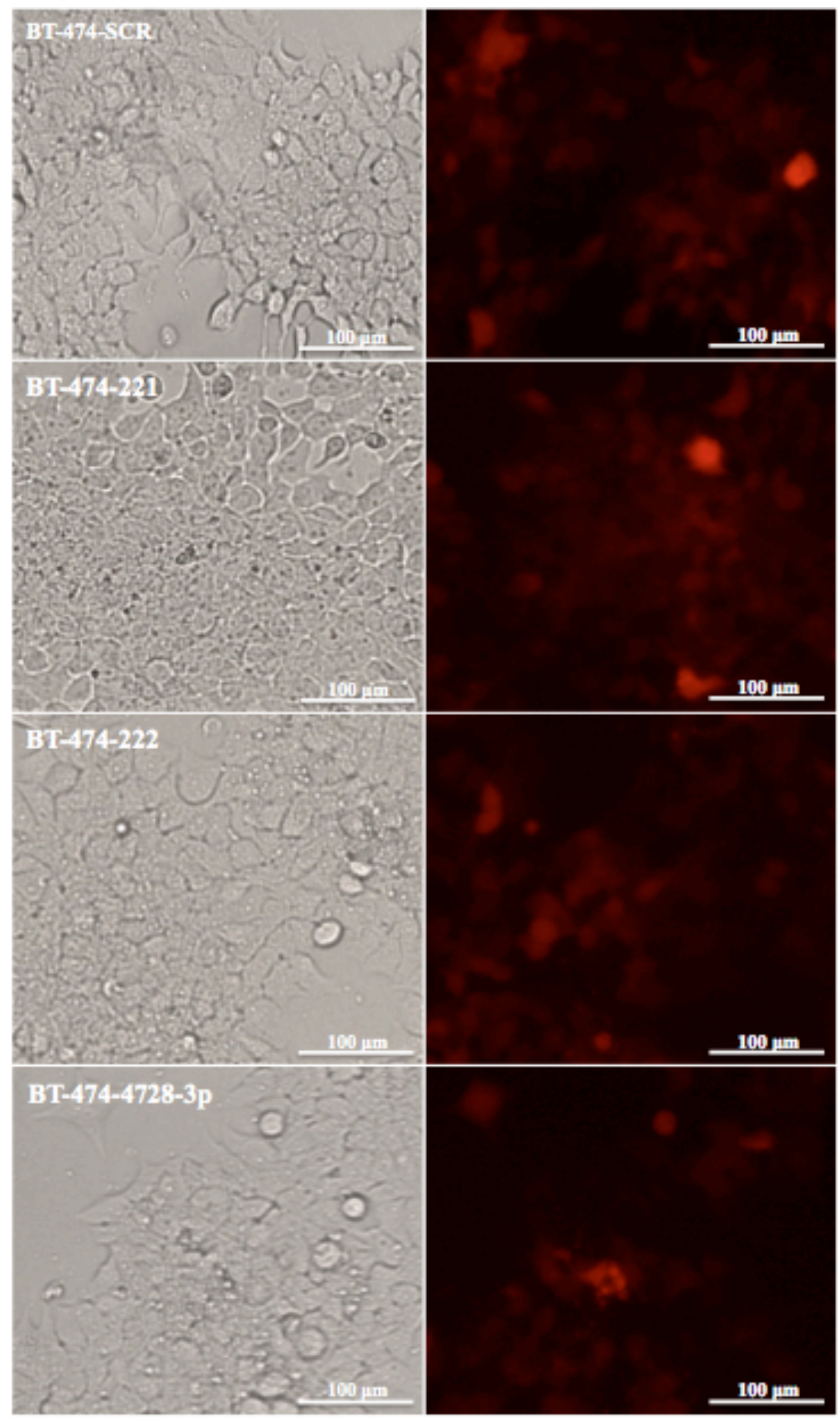




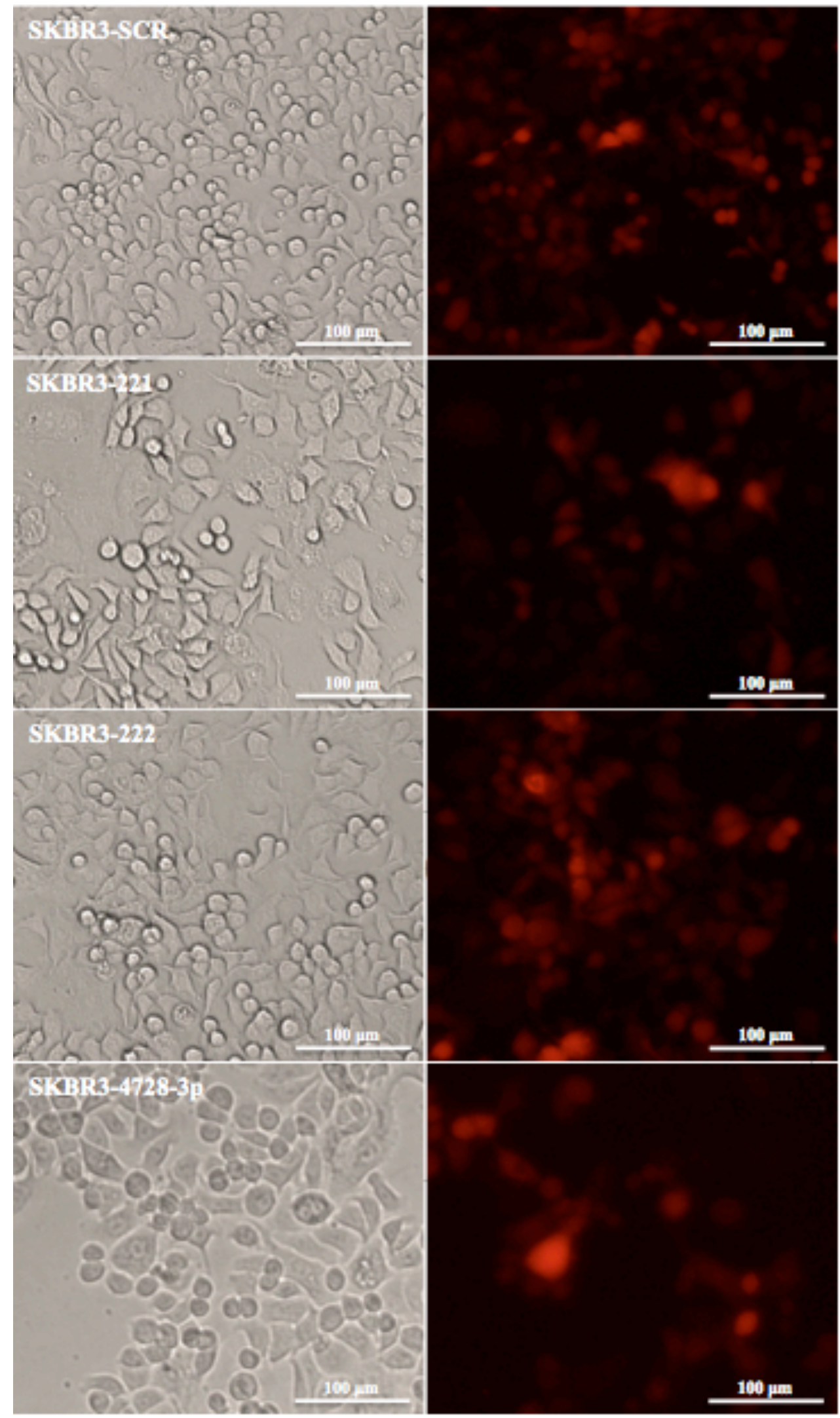

Figura 26 - Imagens fotográficas por microscopia em luz visível e UV linhagens celulares MCF-7, BT-474 e SKBR3 transduzidas com lentivetores para a superexpressão de miR-221, 222 e $4728-3 p$ e RFP. 
A partir das observações no microscópio de fluorescência foi possível notar que a eficiência da transdução com $10 \mu \mathrm{L}$ de sobrenadante não foi $100 \%$ nas 3 linhagens transduzidas com os 4 plasmídeos. Isso leva a uma maior probabilidade de apenas 1 DNA viral ter se inserido no DNA genômico das células-alvo. Através dos cálculos de MOI, considerando o volume de sobrenadante utilizado, o número de células plaqueadas, o título viral uma a eficiência de transdução menor que $100 \%$ com pouca variação entre as linhagens, foi possível estimar o valor de MOI menor que 10 para todas as transduções realizadas acima (Figura 26).

\subsubsection{Expressão dos miRNAs após transdução com lentivetores}

A verificação do efeito das transduções lentivirais sobre a expressão dos miRNAs estudados, foi realizada por qRT-PCR. Ao construto scramble (scr), vetor controle de sequência aleatória, foram designados valores de 1. Estes valores foram então usados como calibradores para o cálculo da expressão relativa das amostras (conforme descrito em Matérias e Métodos).

$\mathrm{Na}$ Figura 27 podemos observar que todas as amostras transduzidas com os construtos para a superexpressão dos miRNAs de interesse apresentaram significativos aumentos de expressão de seus respectivos miRNAs, tanto em relação aos seus níveis endógenos nas mesmas células wt, quanto em relação aos controles scr. 
MCF-7
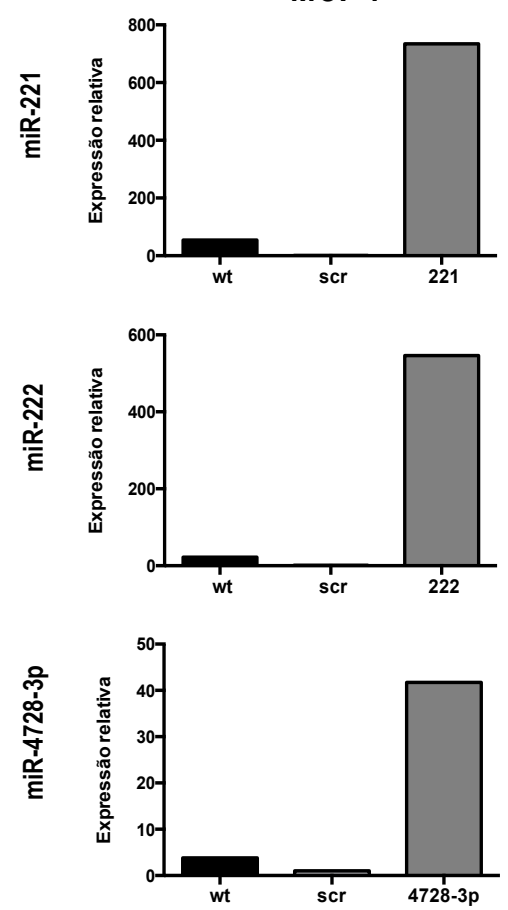

SKBR3
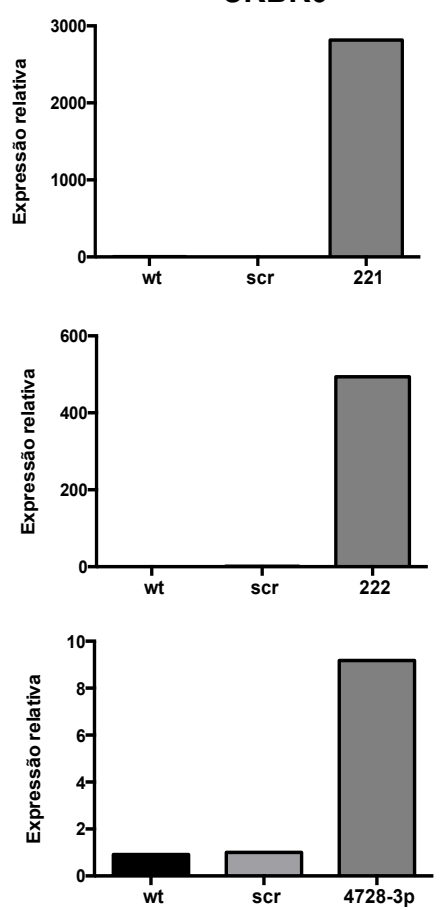

BT-474
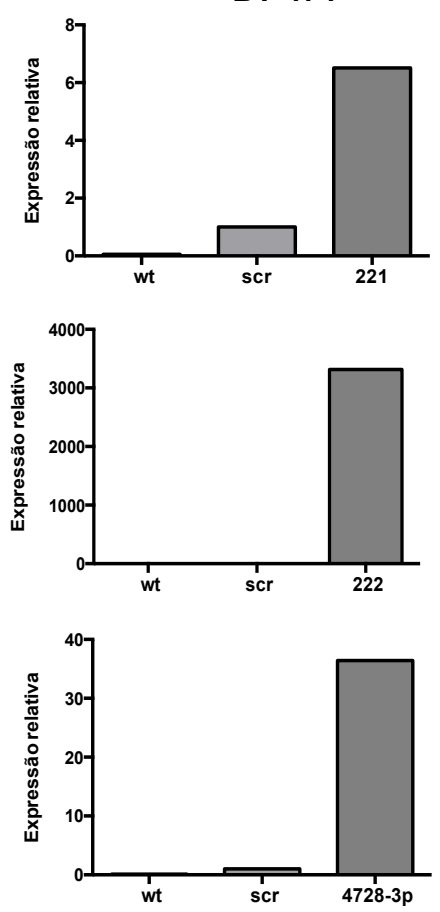

Figura 27 - Quantificação de miR-221, -222 e -4728-3p em células transduzidas. Células wild-type (wt), transduzidas com vetores-controle: scramble (scr), ou com os vetores lentivirais contendo construtos para a superexpressão dos miRNAs de interesse: -221, -222 e -4728$3 \mathrm{p}$.

Os níveis de superexpressão foram variáveis de acordo com a linhagem e com o construto lentiviral. Nas células MCF7, os respectivos níveis de expressão de miR-221, -222 e -4728-3p em relação ao scr foram aproximadamente (734x, 546x e 42x), SKBR3 (2817x, 493x e 9x) e SKBR3 e BT-474 (6,5x, 3316x e 36x).

\subsubsection{Análise e separação da subpopulação $A L D H^{+}$após indução da superexpressão de $\operatorname{miRNAs}$}

A fim de obter subpopulações $\mathrm{ALDH}^{+}$a partir de células MCF-7, BT-474 e SKBR3 após a indução da superexpressão dos miRNAs, foram realizados tratamentos com o reagente Aldefluor ${ }^{\circledR}$ (BAAA) na ausência e na presença de seu inibidor DEAB (controle) e, posteriormente, foram feitas análises e separações por citometria de fluxo. A partir de células wt, foram separadas subpopulações $\mathrm{ALDH}^{+}$e $\mathrm{ALDH}^{-}$.

Abaixo encontram-se os dot-plots representativos das populações $\mathrm{ALDH}^{+}$analisadas e separadas a partir de todas as populações celulares (Figura 28). 
A

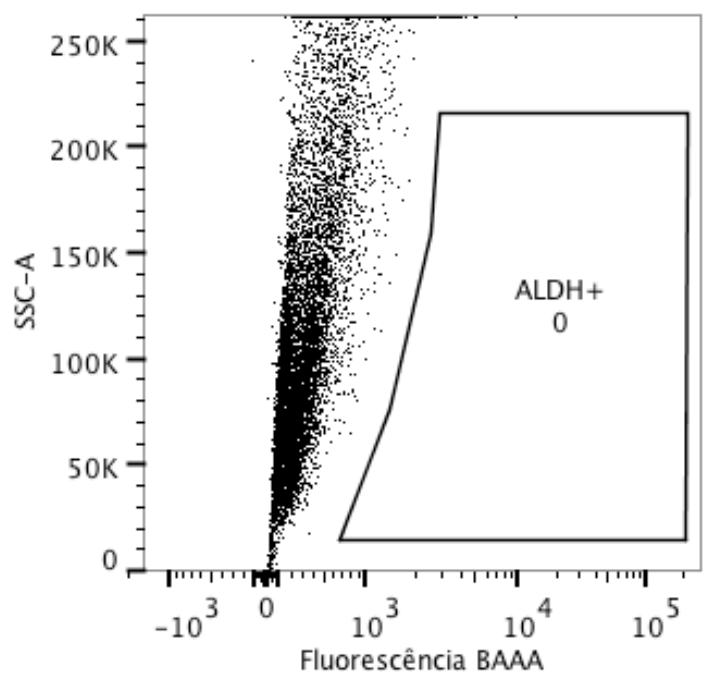

B

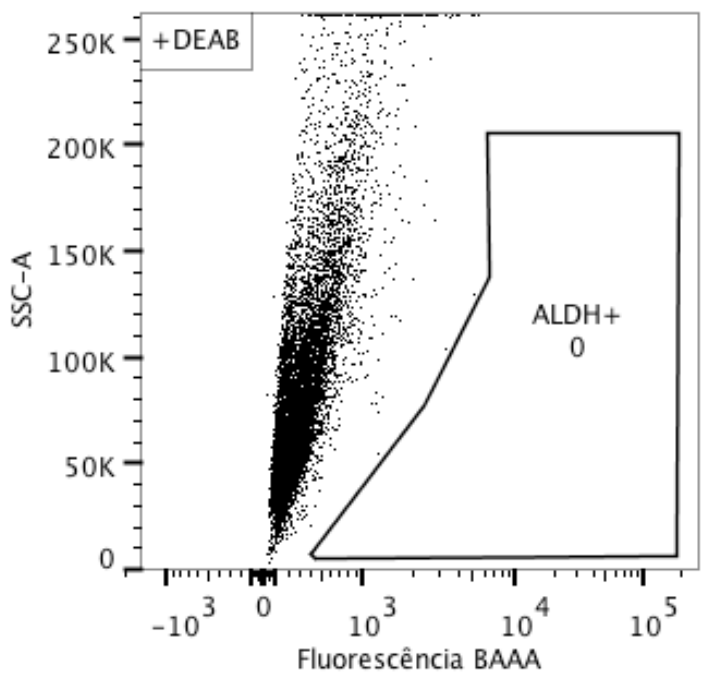

C

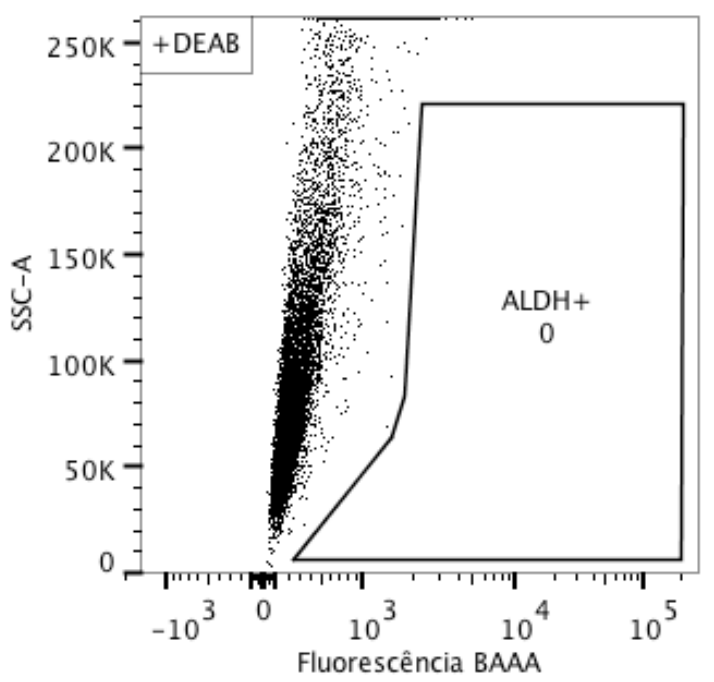

\section{MCF7-wt}

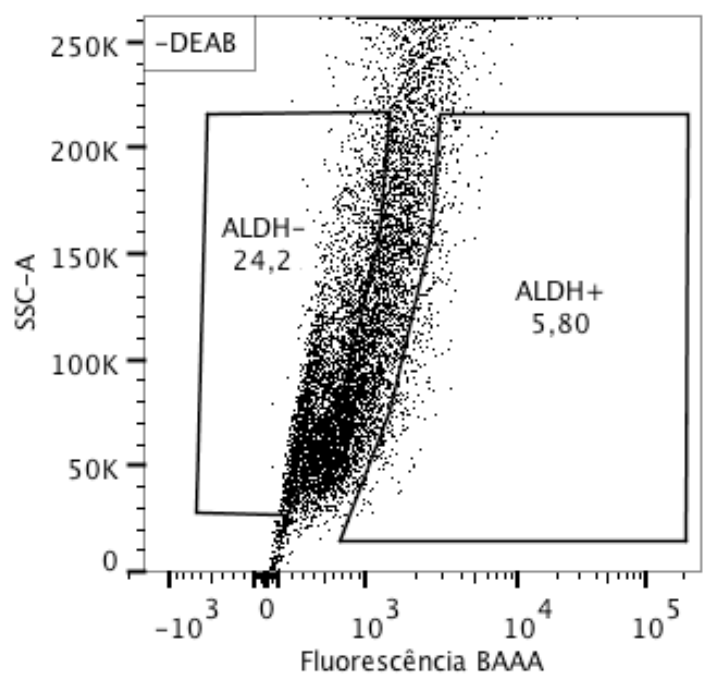

\section{MCF7-scr}

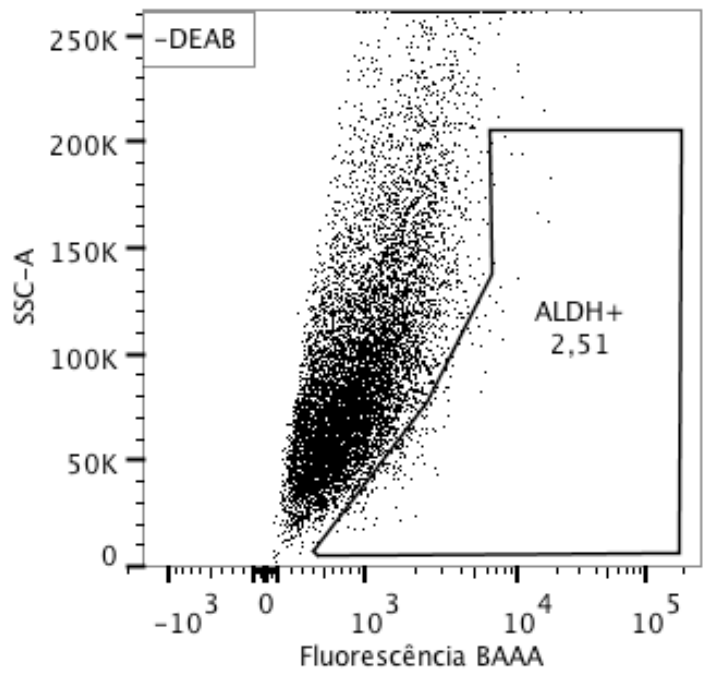

\section{MCF 7-221}

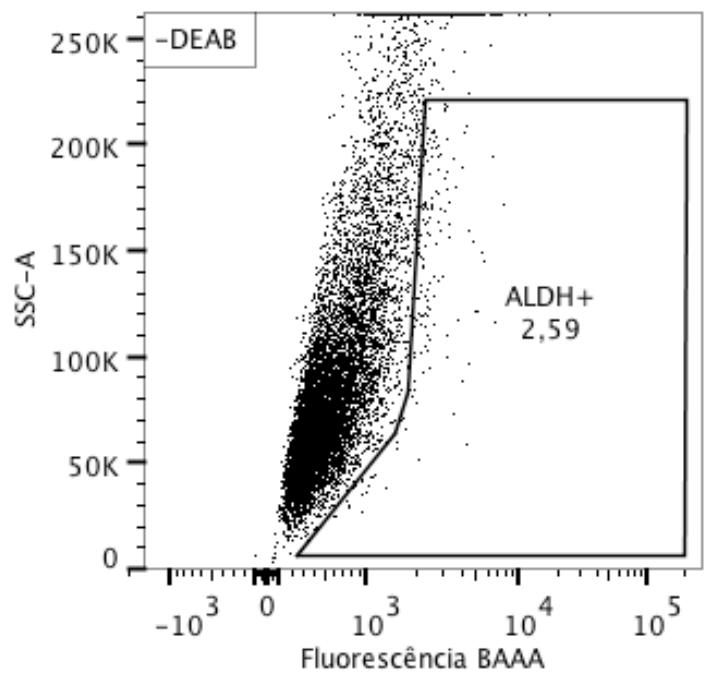


D

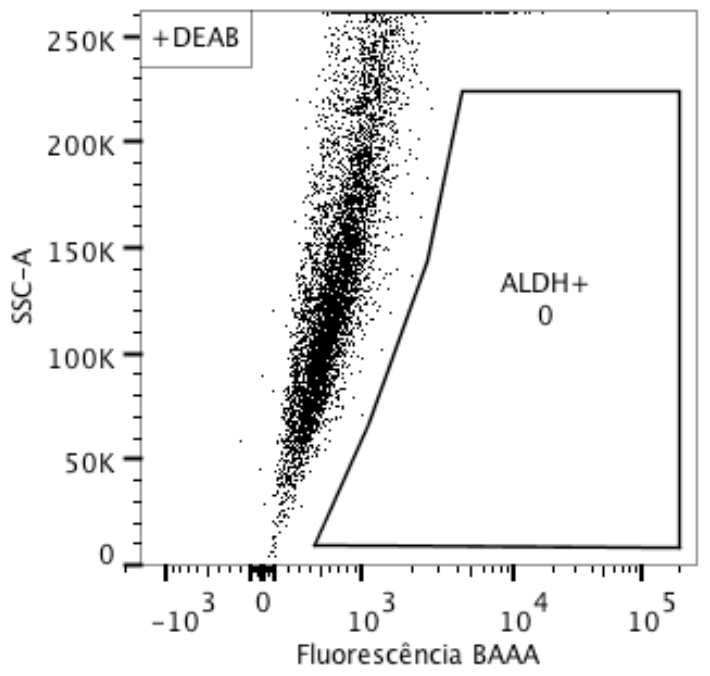

E

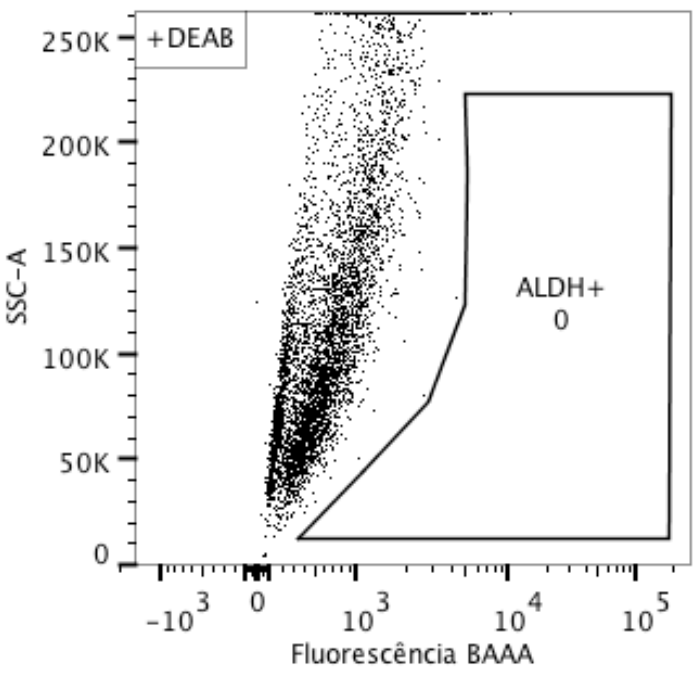

F

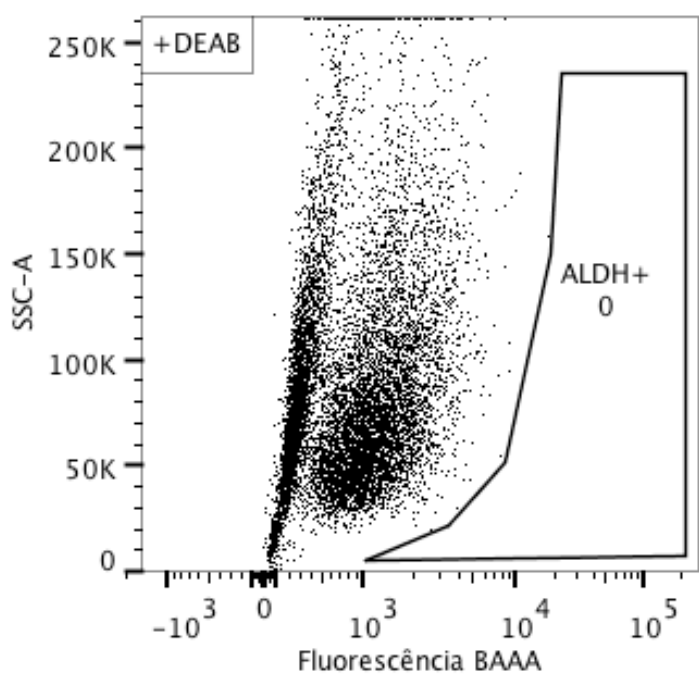

MCF 7-222

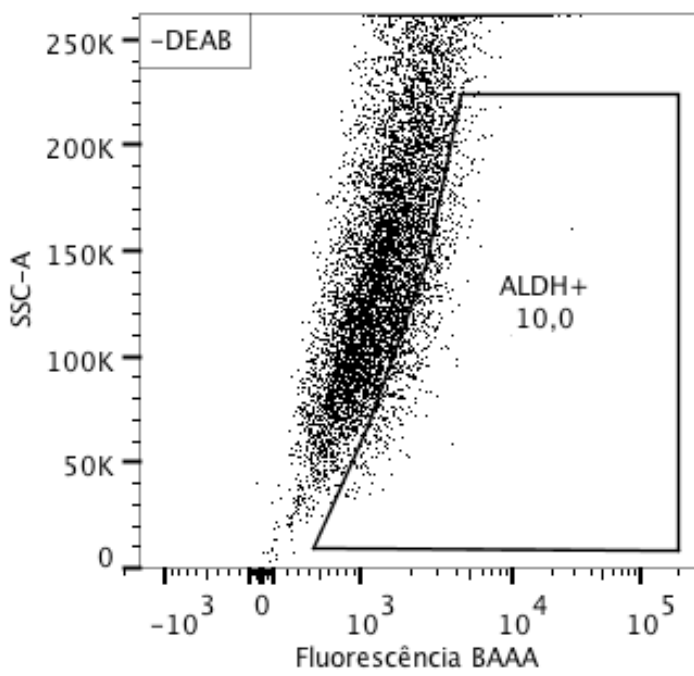

MCF7-4728-3p

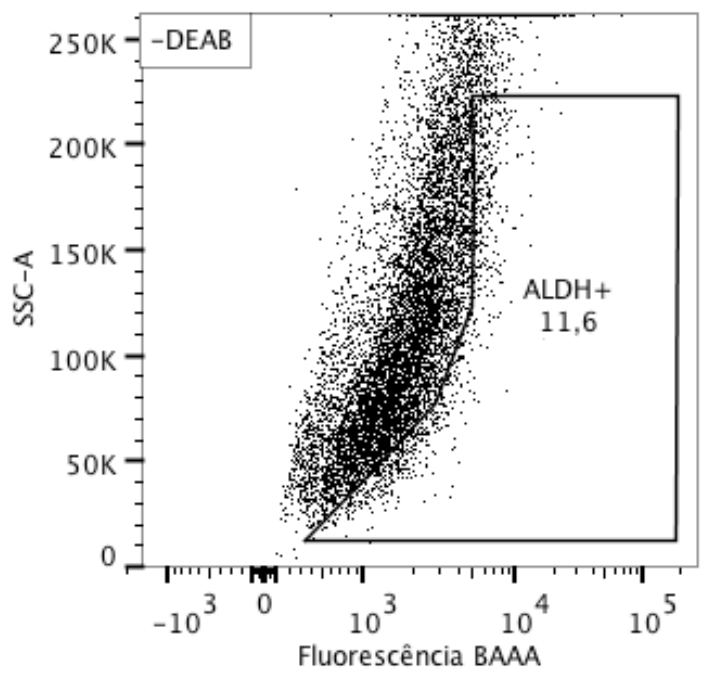

SKBR3-wt

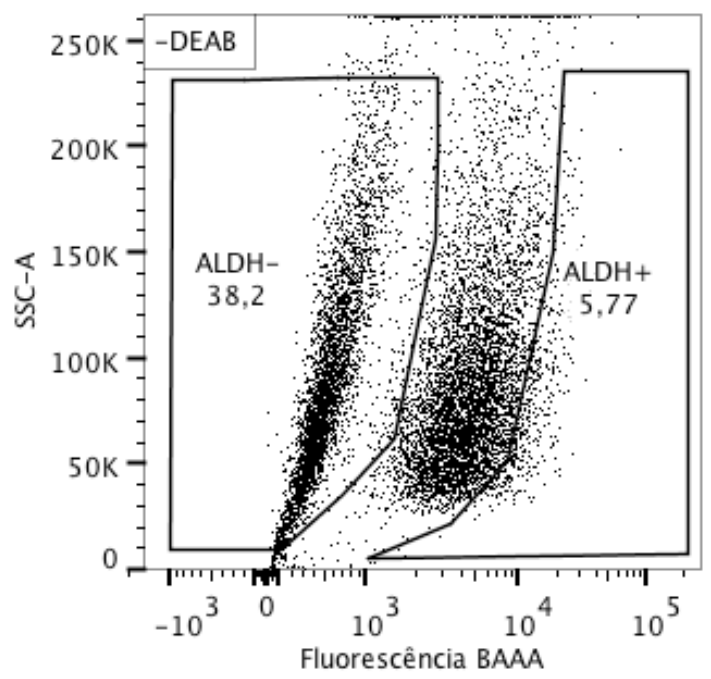


G

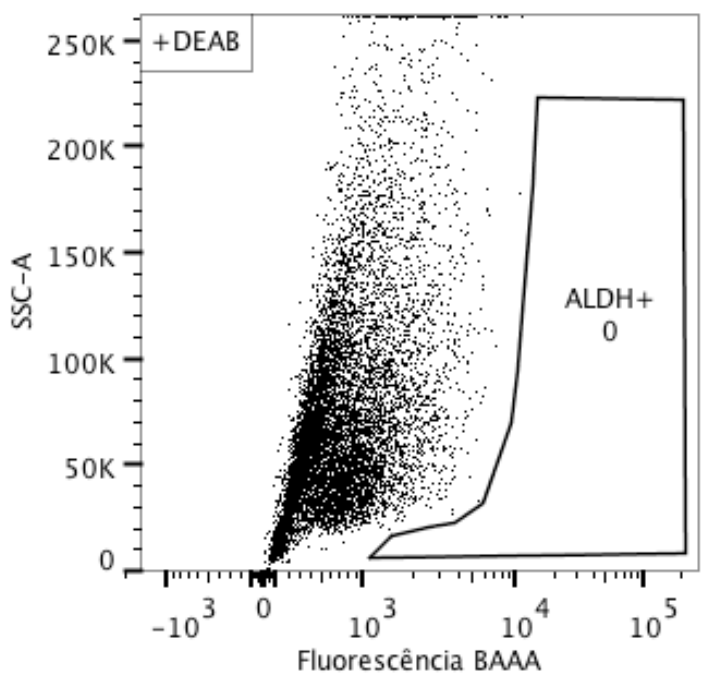

H

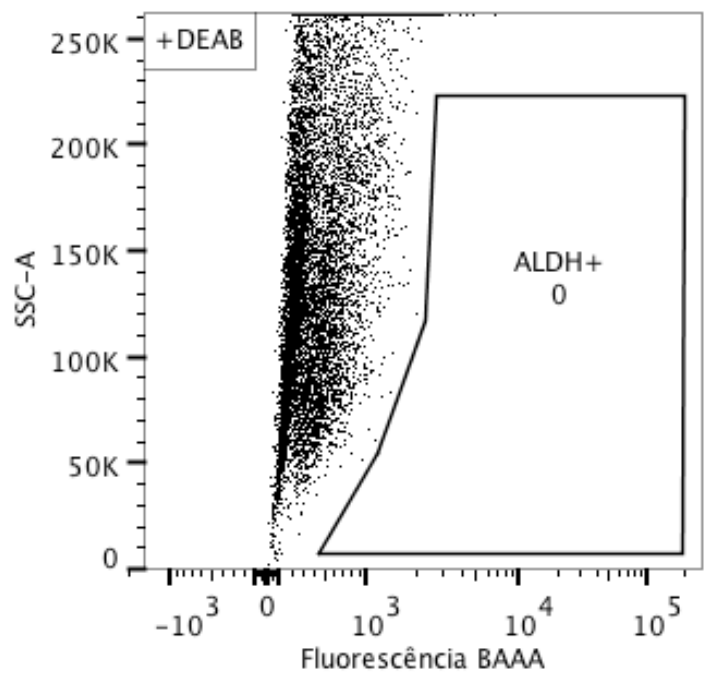

I

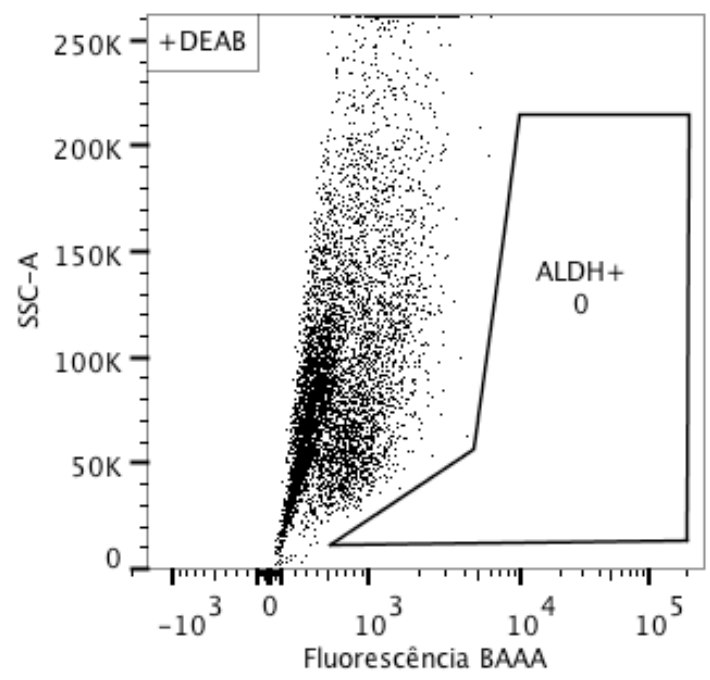

\section{SKBR3-scr}

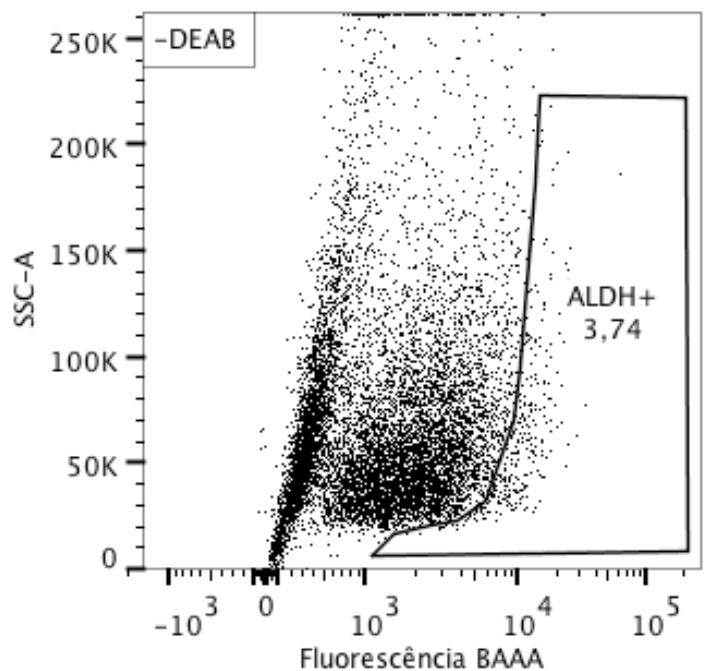

SKBR3-221

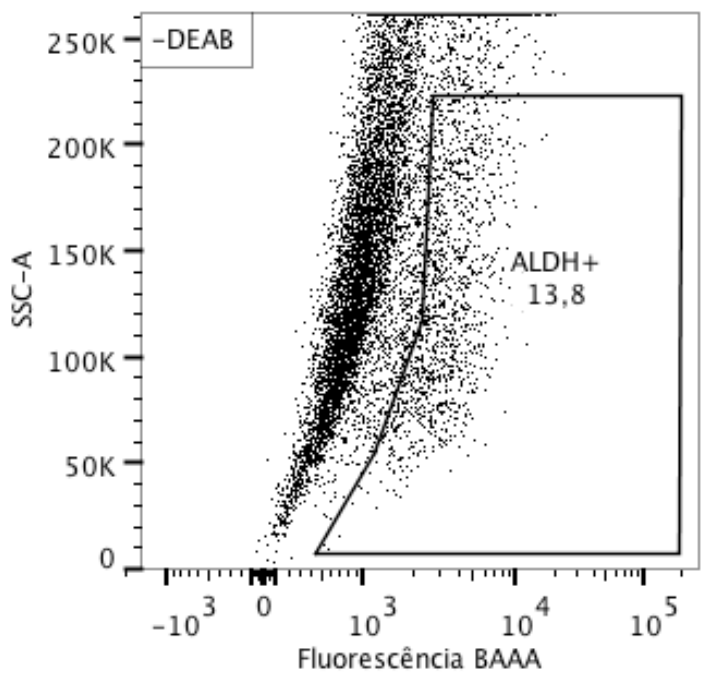

SKBR3-222

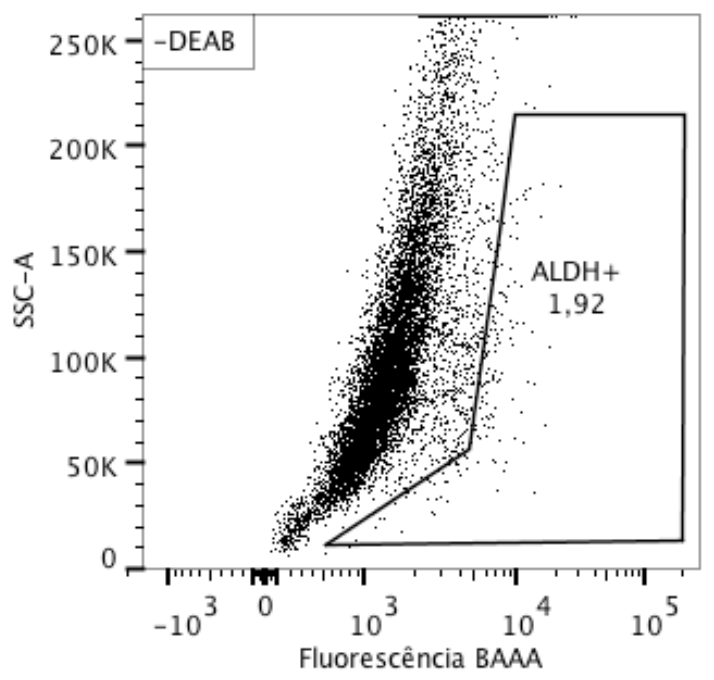


J

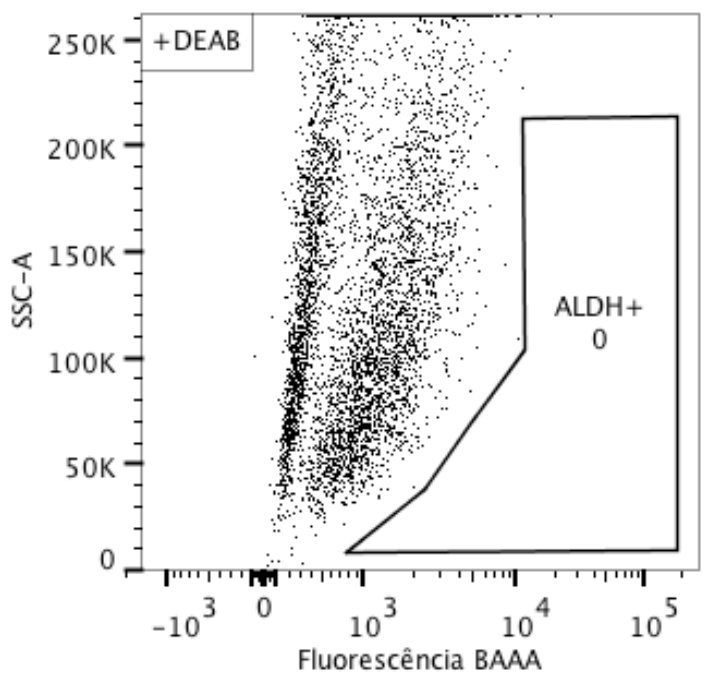

K

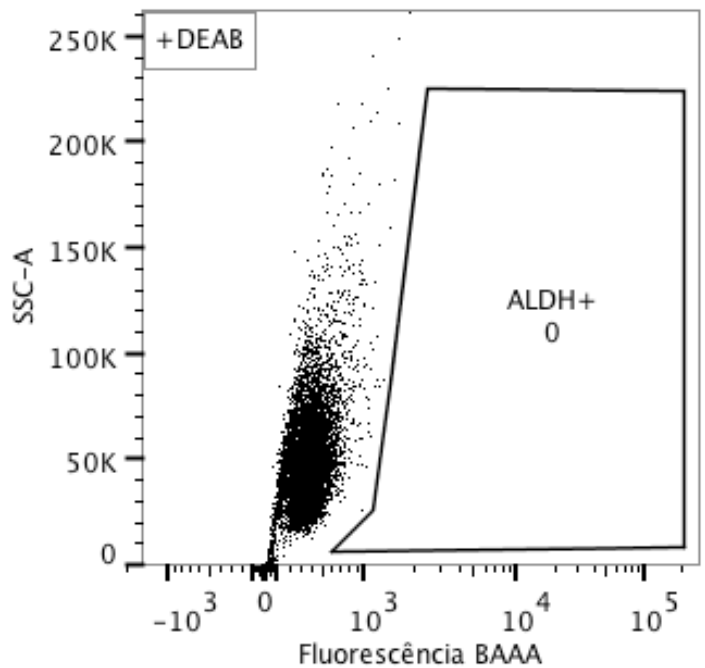

L

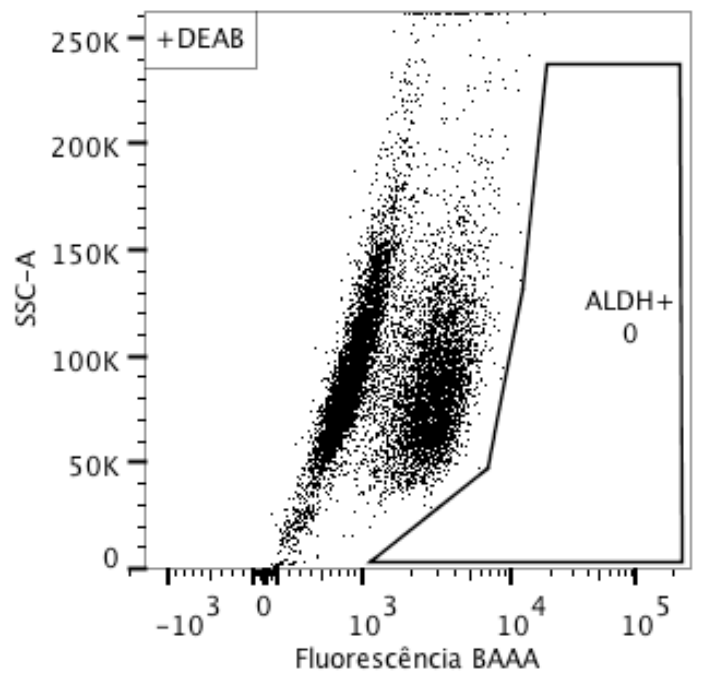

\section{SKBR3-4728-3p}

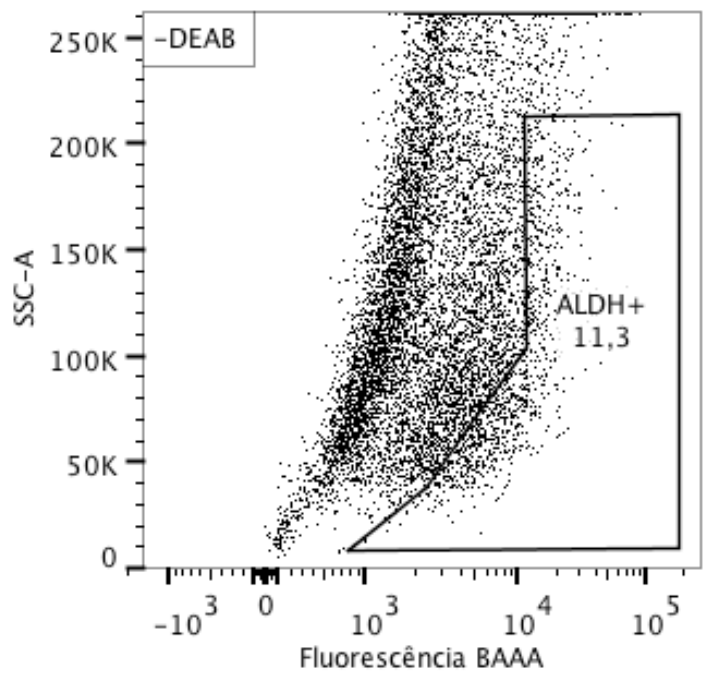

BT-474-wt

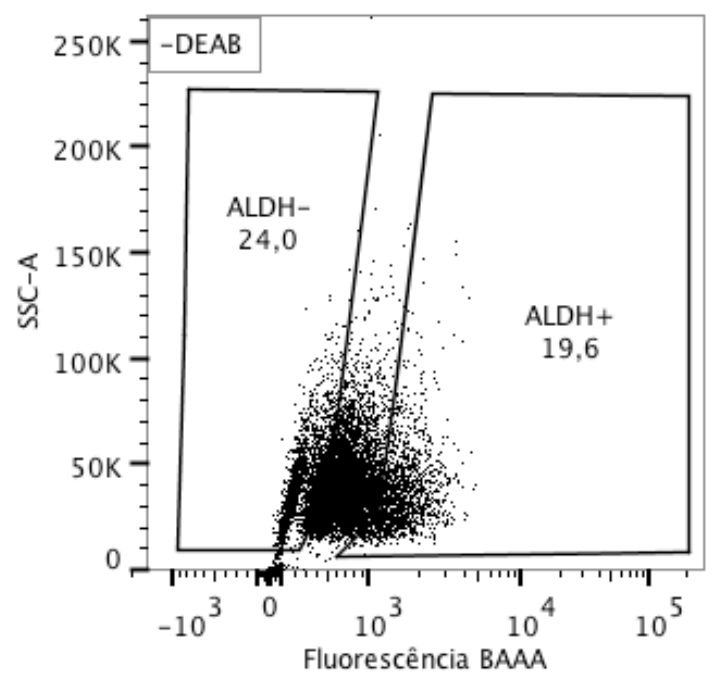

\section{BT-474-scr}

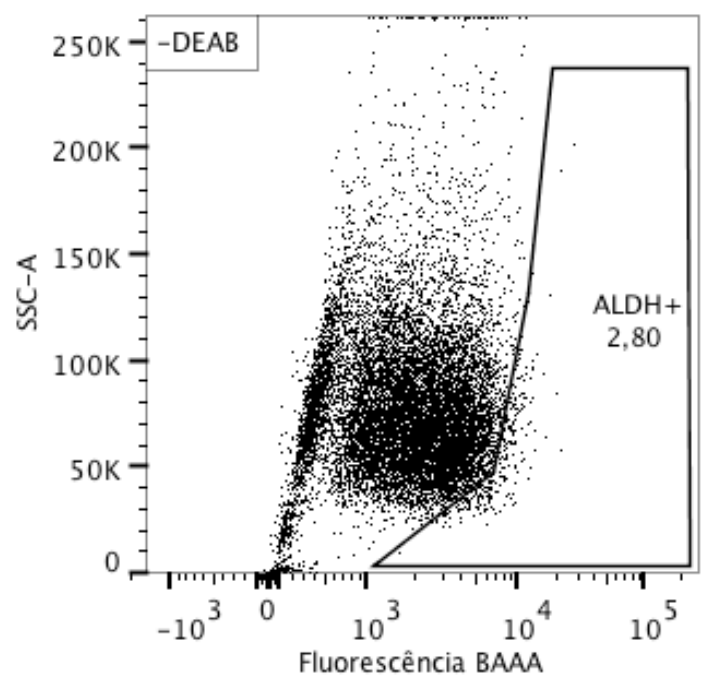


M

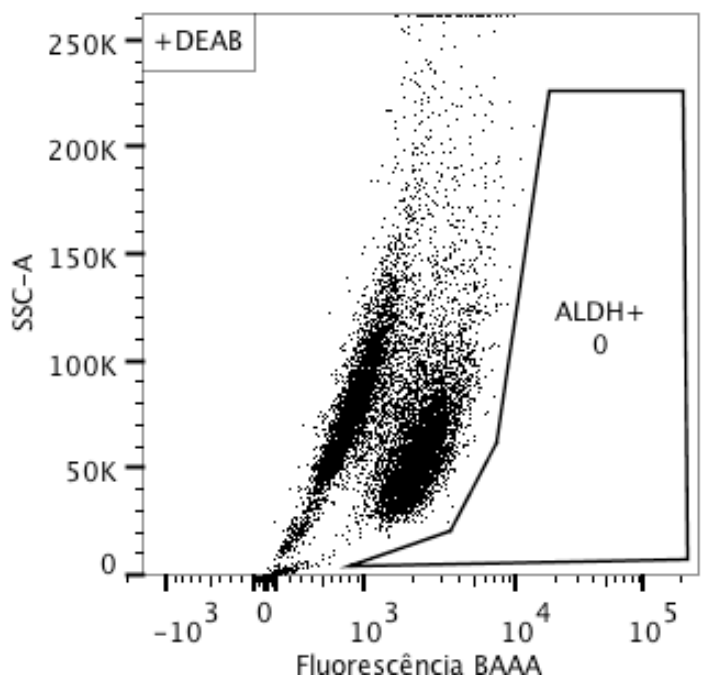

$\mathbf{N}$

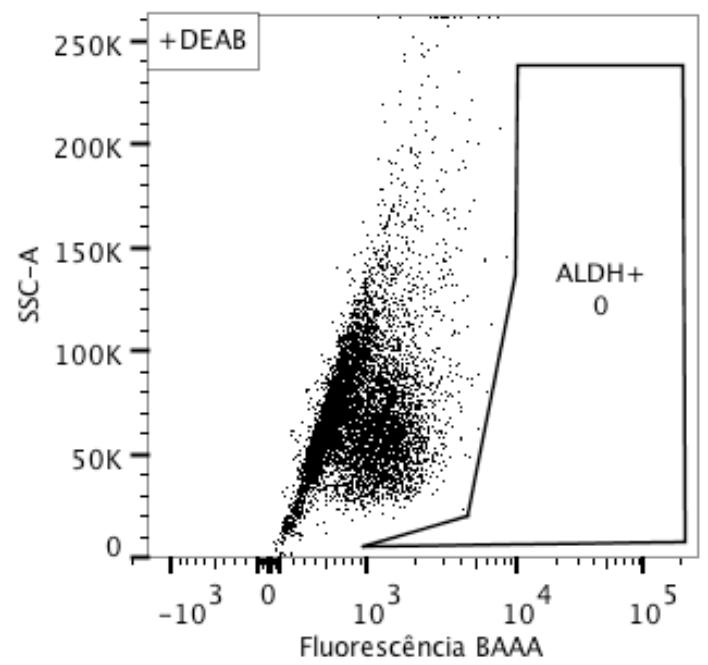

o

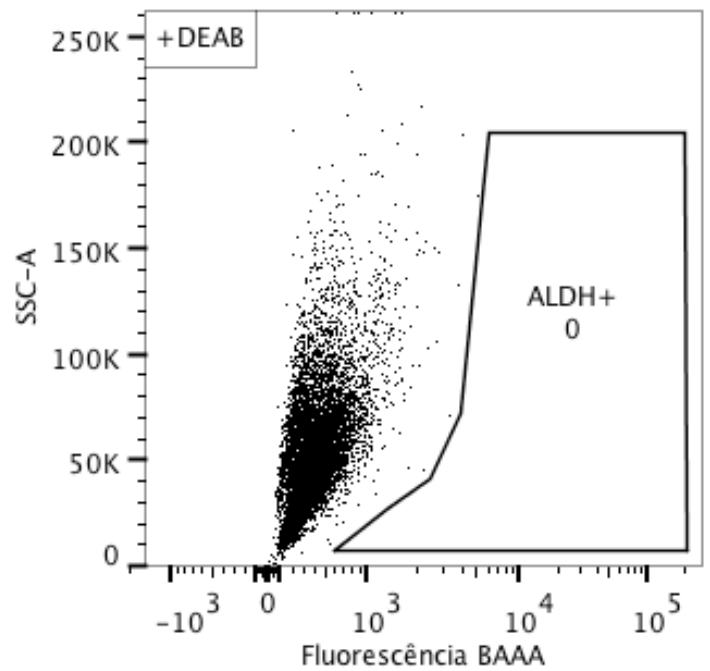

\section{BT-474-221}

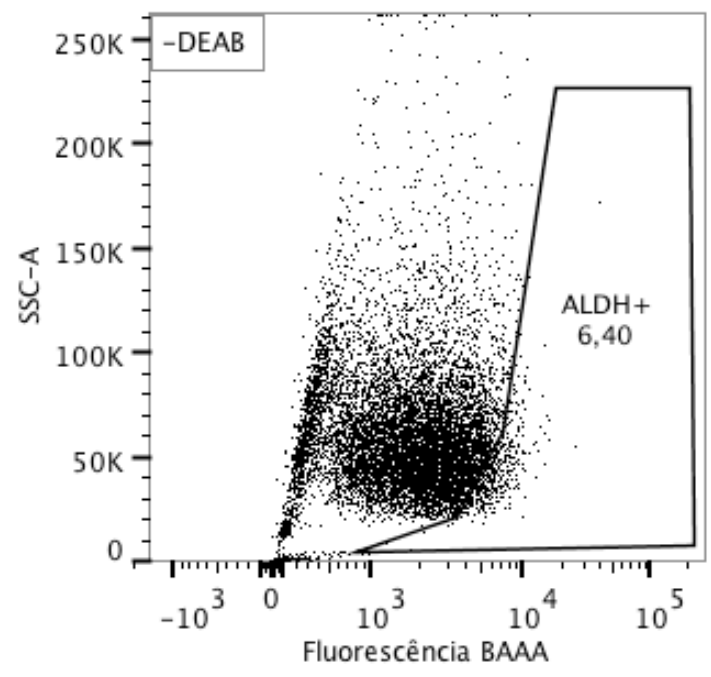

\section{BT-474-222}

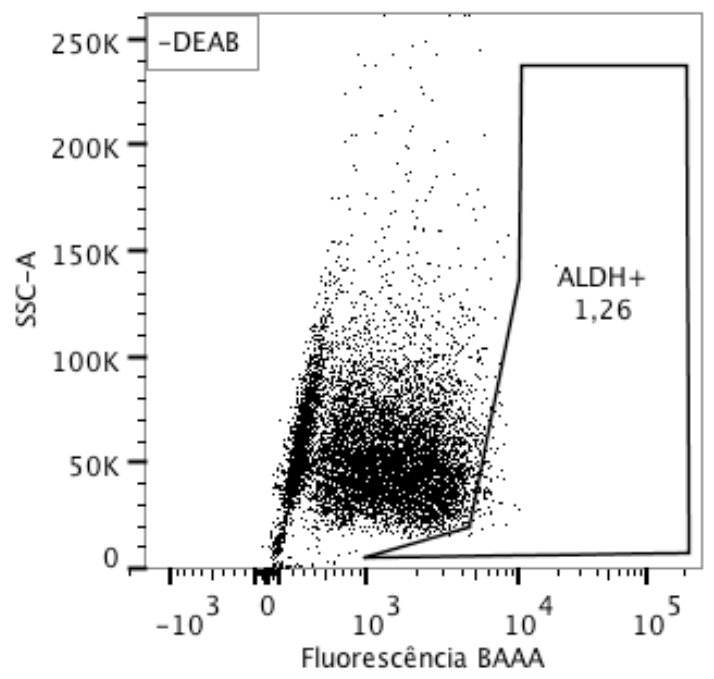

BT-474-4728-3p

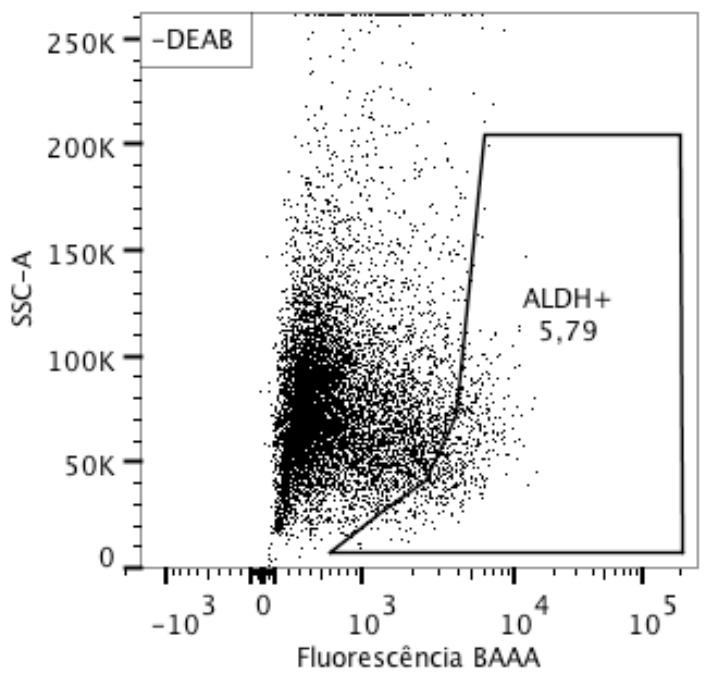


Figura 28 - Dot plots representativos da porcentagem de células ALDH1 ${ }^{+}$entre as células aderentes das linhagens MCF-7, BT-474 e SKBR3 transduzidas com os construtos scr, $-221,-222$ e $-4728-3 p$.

Os gráficos comparativos dos percentuais das subpopulações $\mathrm{ALDH}^{+}$derivadas de cada linhagem e na presença de superexpressão de cada miRNA são apresentados a seguir (Figura 29).

A

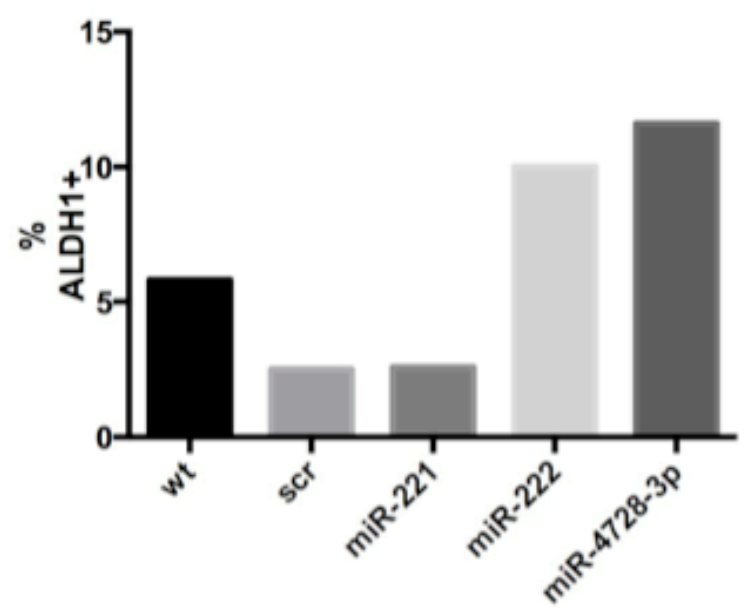

B

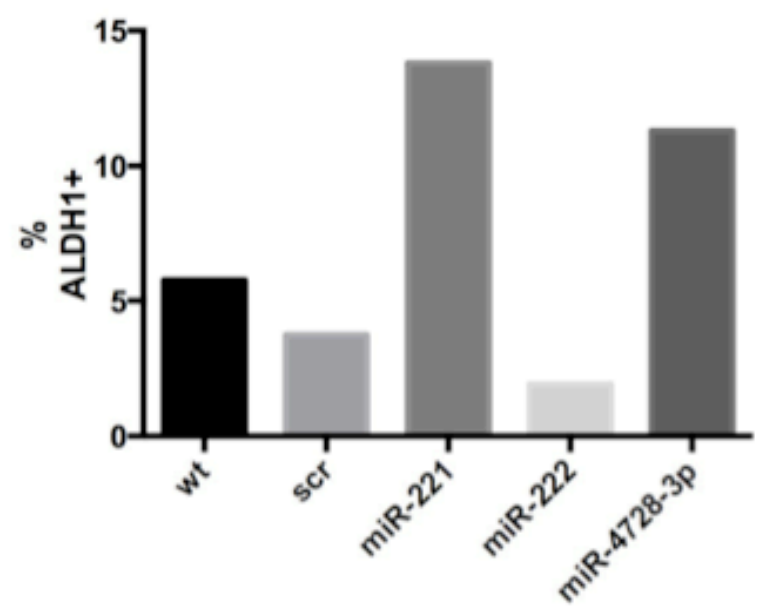

C

BT-474

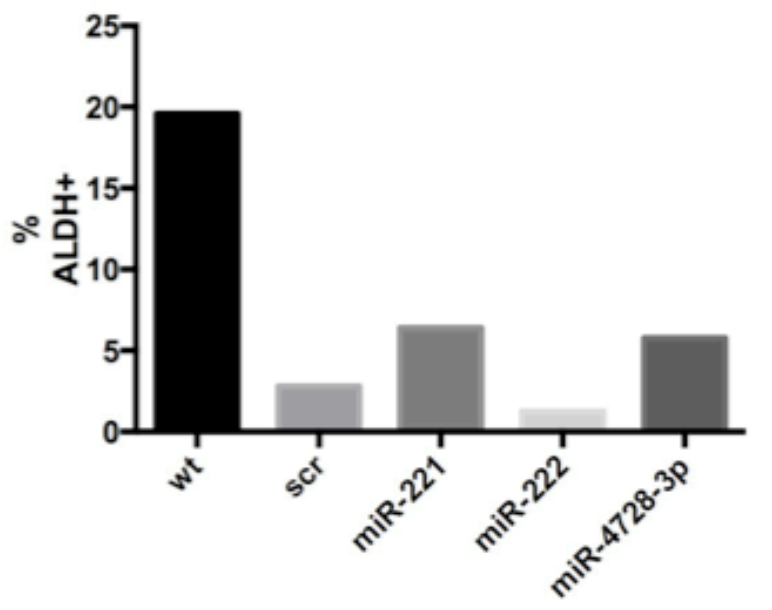

Figura 29 - Percentuais de subpopulações $\mathrm{ALDH}^{+}$em linhagens wt, controle e em células com superexpressão de miR-221, -222 e -4728-3p. Os gráficos apresentam os percentuais das subpopulações ALDH ${ }^{+}$em células MCF-7 (A), SKBR3 (B) e BT-474 (C) para wt, controle (scr), e células com superexpressão dos miRNAs -221, -222 e -4728-3p.

Conforme mostrado nas Figuras 29A, B e C , as frações de células $\mathrm{ALDH}^{+}$em células wt das linhagens MCF-7, SKBR3 e BT-474 foram, respectivamente, 5,8\%, 5,7\% e 19,6\%. 
Em células MCF-7 transduzidas com o scr, miRNAs -221, -222 e -4728-3p (Figura 29A) as subpopulações $\mathrm{ALDH}^{+}$foram, respectivamente, $2,5 \%, 2,59 \%, 10 \%$ e 11,6\%, respectivamente.

Em células SKBR3 transduzidas com o scr, miRNAs -221, -222 e -4728-3p (Figura 29B) os percentuais de subpopulações $\mathrm{ALDH}^{+}$foram, respectivamente, 3,74\%, 13,8\%, 1,92\% e $11,3 \%$, respectivamente.

Os percentuais de subpopulações $\mathrm{ALDH}^{+}$foram em células BT-474 transduzidas com o scr, miRNAs -221, -222 e -4728-3p (Figura 29C) foram, respectivamente, 2,8\%, 6,4\%, $1,6 \%$ e $5,79 \%$.

Verifica-se aumentos nesses percentuais em MCF-7 e SKBR-3 que superexpressam o miRNA-4728-3p tanto em relação ao contole quanto em relação às células wt. Da mesma forma, esses aumentos são observados em células MCF-7 que superexpressam o miRNA-222 e em células SKBR3 que superexpressam o miRNA-221. Os demais percentuais nessas duas linhagens encontram-se diminuídos em relação às células wt.

Células BT-474 que superexpressavam os miRNAs -221 e -4728-3p apresentaram percentuais aumentados de $\mathrm{ALDH}^{+}$em relação ao controle. Nesta linhagem observaram-se, em relação às células wt, reduções significativas nos percentuais de todas as populações celulares analisadas.

Apesar do percentual de células $\mathrm{ALDH}^{+}{ }^{+}$em algumas populações transduzidas serem relativamente baixos foi possível seu isolamento a partir de células aderentes e cultivo.

\subsubsection{Ensaio de proliferação em células BT-474 transduzidas}

Até agora foi possível realizar apenas um ensaio de proliferação com células wt e transduzidas da linhagem BT-474, uma vez que as demais linhagens ainda apresentam baixas quantidades de células.

Abaixo encontra-se o gráfico que mostra os valores de índices celulares gerados pelo aparelho $x$ CELLigence (Roche), avaliados em intervalos de 1 hora (Figura 30). 


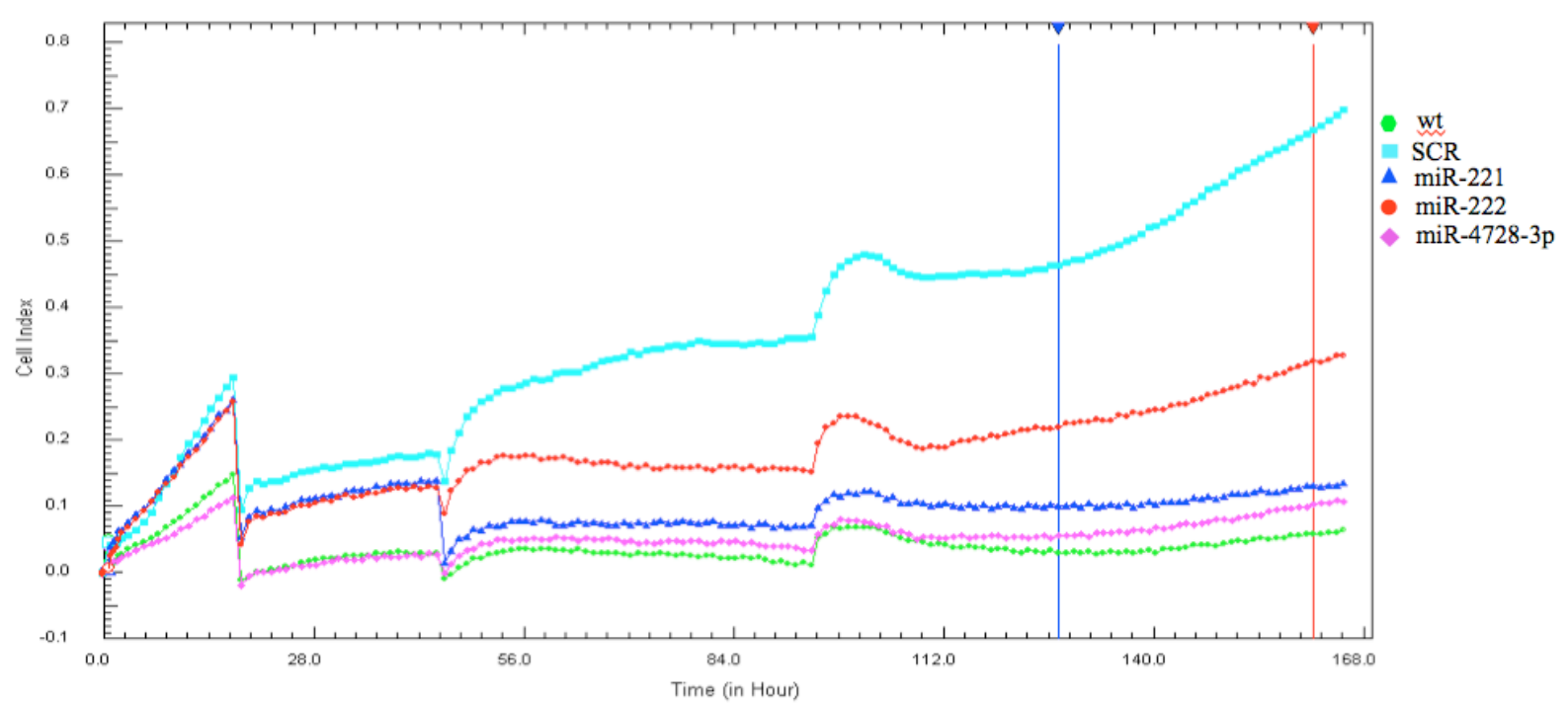

Figura 30 - Índices celulares calculados por impedância em intervalos de 1 hora em células BT-474 superexpressando miR-221, -222 e -4728-3p. Wild-type (wt-verde), controle (scr-azul claro) e com superexpressão de miR-221 (azul escuro), -222 (vermelho) e -4728-3p (lilás). A demarcação indica o intervalo de 127-161h analisado.

No intervalo indicado acima (Figura 30) foram calculados os valores de slope (inclinação da reta) de células BT-474 wt, scr e com superexpressão dos miRNAs -221, -222 e $-4728-3 p$ (Figura 31)

\section{Proliferacão}

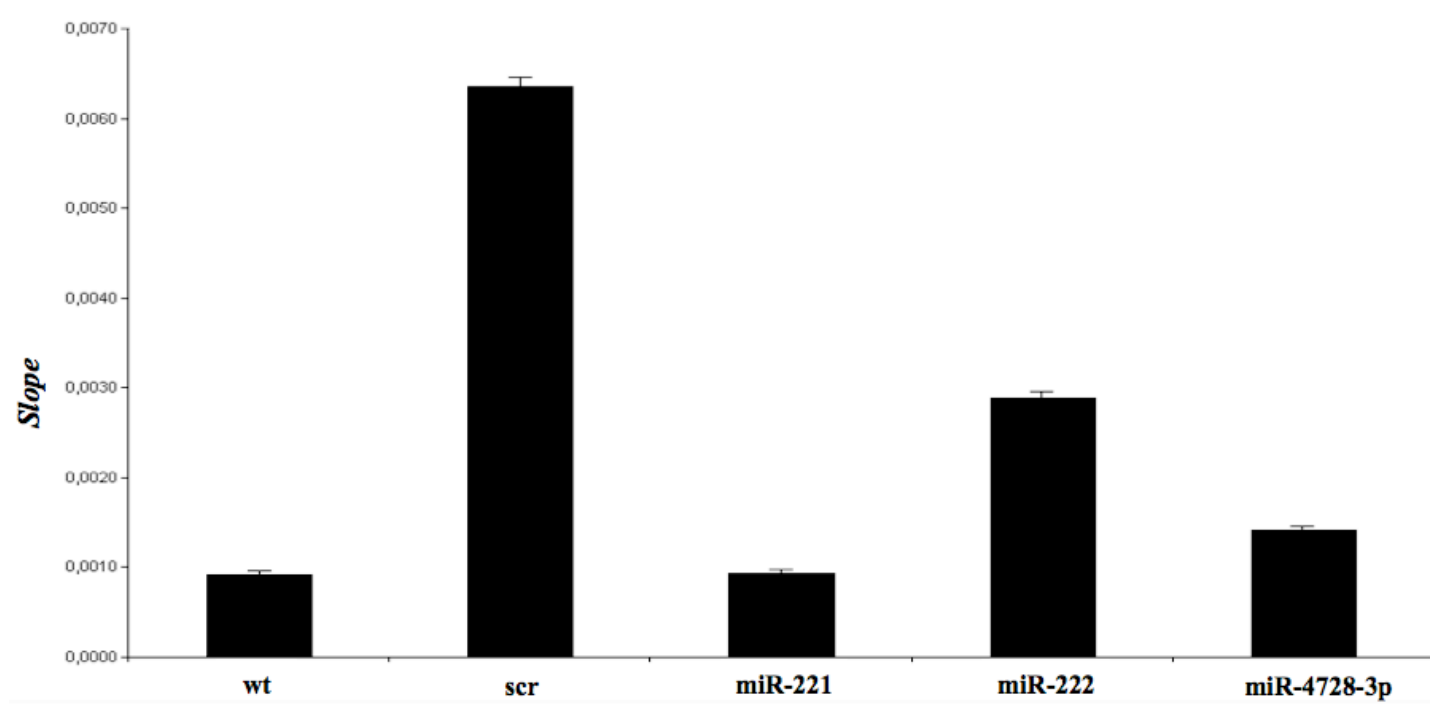

BT-474

Figura 31 - Valores de slope calculados em um intervalo de tempo de 34h em células BT-474 com superexpressão de miR-221, -222 e -4728-3p. Wild-type (wt), controle (scr) e com superexpressão de miR-221, -222 e -4728-3p. Os valores de slope foram calculados a partir da média dos índices celulares (triplicatas) e são diretamente proporcionais ao índice de proliferação celular em cada um dos experimentos. 
A partir desses resultados (Figura 31), em células BT-474, foram observados valores aproximados de slope para células wt, scr e que superexpressam miR-221, -222 e 4728-3p, respectivamente, 0,001;0,006;0,001; 0,003 e 0,0015. O valor de slope do scr foi aproximadamente 6x maior do que em células wt, o que sugere que células transduzidas com o lentivetor scr poderiam estar desenvolvendo algum efeito inespecífico envolvido nas vias de proliferação celular. Porém, mais experimentos deverão ser realizados a fim de confirmar este resultado. Devido a esse problema, as demais anáises comparativas envolvendo proliferação foram prejudicadas, uma vez que não se tem um controle adequado para compará-las.

\subsubsection{Ensaio de citotoxicidade}

A fim de determinar valores de IC50, foram realizados ensaios de citotoxicidade dos quimioterápicos paclitaxel em células wt das linhagens SKBR3 e BT-474 (Figura 31)

A

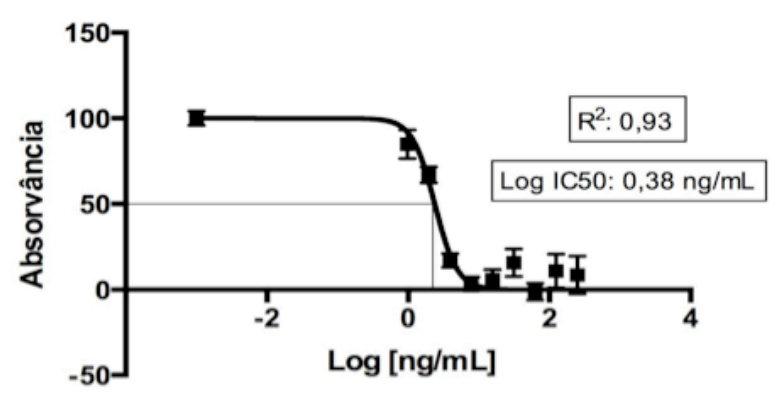

Paclitaxel
B

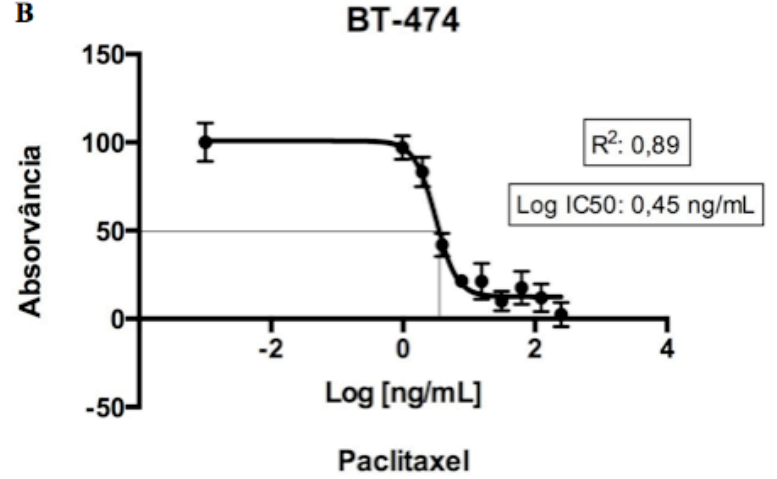

Figura 32 - Valores de IC50 do quimioterápico paclitaxel em células wt das linhagens SKBR3 e BT-474. Os pontos indicam a média (6 replicatas) das absorbâncias (esq-dir) do controle (células-não tratadas), e nove concentrações crescentes.

Os valores de IC50 são mostrados na Figura 32 e serão utilizados para os próximos experimentos de apoptose envolvendo essas linhagens celulares com expressão alterada dos miRNAs de interesse. Os gráficos referentes ao tratamento dessas linhagens com o quimioterápico trastuzumabe não foram mostrados aqui, pois as células apresentaram comportamento muito semelhante nas oito maiores concentrações das curvas, o que impossibilitou plotar a curva completa de regressão não-linear levando a valores baixos de $\mathrm{R}^{2}$ e um cálculo impreciso da IC50. 


\subsection{Conclusões}

\subsubsection{Capítulo I}

- A geração de mamosferas a partir da linhagem celular MCF-7 e de amostras de pacientes foi bem sucedida. Mamosferas derivadas da linhagem MCF-7 mostraram-se maiores e eram constituídas por células bem aderidas entre si. Mamosferas obtidas a partir de tumores eram constituídas de células CD $44^{+} / \mathrm{CD} 24^{-}$e se mostraram menores e constituídas de células menos aderidas entre si, o que pode sugerir um perfil basal ou de EMT nessas células;

- A expressão de marcadores de pluripotência de células-tronco embrionárias $S O X 2$, NANOG e OCT4 em mamosferas derivadas tanto da linhagem MCF-7 quanto de células derivadas de tumores primários das pacientes mostrou-se elevada, o que sugere um enriquecimento de CSCs pluripotentes nas mamosferas provenientes desses tipos celulares;

- As frações celulares separadas de CD44 $4^{+}$e CD24- da linhagem MCF-7 foi maior em mamosferas do que em células aderentes, o que pode sugerir um enriquecimento de CSCs com o fenótipo CD44 ${ }^{+} / \mathrm{CD} 24^{-}$em mamosferas dessa linhagem;

- Para todas as amostras estudadas, a expressão de miR-221 e miR-222 encontrava-se aumentada quando células aderentes foram comparadas a mamosferas, o que reforça o papel destes miRNAs na regulação de CSCs;

- Células MCF-7 apresentaram maior eficiência na formação de mamosferas após a indução confirmada da superexpressão de miR-221 e miR-222, o que sugere um possível papel desses miRNAs na biologia de CSCs;

- Células MCF-7 apresentaram maior resistência à morte celular quando tratadas com paclitaxel após a indução da superexpressão de miR-222, sugerindo um papel desse miRNA na regulação de morte celular de CSCs.

\subsubsection{Capítulo II}

- Mamosferas foram obtidas a partir de células das linhagens MCF-7, BT-474 e SKBR3. Mamosferas maiores e em maior quantidade foram formadas a partir de BT474, seguida por MCF-7 e SKBR3; 
- Mamosferas obtidas a partir de células da linhagem MCF-7, sem amplificação de HER2, apresentaram pelo menos o dobro de expressão de HER2 em todas as 4 gerações. Este fato reforça a importância de HER2 na biologia de CSCs e sua possível relevância no tratamento de pacientes que não sejam HER2+;

- O estudo do perfil de expressão de cinco marcadores de pluripotência de célulastronco embrionárias (SOX2, NANOG, OCT4, KLF4 e LIN28) nas três linhagens de mama mostrou expressão elevada de SOX2, NANOG, OCT4 nas culturas de mamosferas da linhagem MCF-7 quando comparadas com as células aderentes em concordância com o capítulo I. Os demais aumentos foram pontuais, o que sugere que estes não são marcadores universais para CSCs de linhagens de mama;

- O fenótipo $\mathrm{CD} 44^{+} / \mathrm{CD} 24^{-/ \text {baixo }}$ estava presente em uma pequena fração das células de mamosferas das três linhagens estudadas, o que sugere que esse fenótipo não seja o mais adequado para CSCs destas mamosferas;

- O perfil de expressão dos miRNAs em células aderentes e de mamosferas da linhagem MCF-7 e linhagens HER2+, BT-474 e SKBR3 mostra que existe uma variabilidade na expressão endógena dos miRNAs ao longo dos tempos de cultivo. Isso sugere a necessidade do estudo mais aprofundado desses miRNAs na biologia de CSCs;

- Mamosferas de todas as linhagens apresentaram um enriquecimento de células $\mathrm{ALDH}^{+}$quando comparadas com as células aderentes. Este achado sugere que essas mamosferas podem estar enriquecidas de CSCs e que ALDH1 pode ser um marcador útil no estudo de CSCs derivadas das linhagens MCF-7, BT-474 e SKBR3;

- A superexpressão dos miRNAs aqui estudados foi bem sucedida. A expressão elevada de miR-4728-3p levou a um aumento das subpopulações $\mathrm{ALDH}^{+}$nas linhagens MCF-7 e SKBR3. Para as células SKBR3 e BT-474 a superexpressão de miR-222 resultou em uma diminuição das frações $\mathrm{ALDH}^{+}$. Em conjunto os resultados reforçam o envolvimento destes miRNAs na regulação da produção de CSCs ALDH1+. 


\subsection{Perspectivas futuras}

O estudo da biologia e do papel de CSCs em câncer de mama é um aspecto extremamente atual e relevante. A heterogeneidade tumoral aparece como um fator de grande importância no manejo clínico das pacientes e a classificação das mesmas em diferentes subtipos pode mudar durante a evolução clínica. Trabalhos recentes consolidam o conceito de que o status de HER2 apresenta relevante variação entre componentes diversos de um tumor, incluindo não apenas variações no próprio tumor primário, mas também em células tumorais circulantes e micrometástases ocultas ao diagnóstico. Deste modo, não apenas as CSCs têm um papel cada vez mais claro no estabelecimento de metástases à distância, como HER2 tem sua importância ainda mais reconhecida para o tratamento de um grupo mais amplo de pacientes.

Neste contexto, além dos resultados apresentados nas páginas anteriores, este trabalho gerou uma grande quantidade de reagentes que serão fundamentais para a continuidade dos estudos que buscam relacionar HER2, CSCs e os miRNAs aqui estudados. Deste modo, as perspectivas futuras desta linha de pesquisa incluem:

- Realizacão de ensaios funcionais (proliferação, resistência à apoptose e migração/invasão) com as células $\mathrm{ALDH}^{+}$obtidas a partir das linhagens MCF-7, BT474 e SKBR3 que superexpressam miR-221, -222, -4728-3p;

- O knockdown dos miRNAs -221, -222, -4728-3p nessas mesmas linhagens já foi realizado (dados não apresentados), portanto a próxima etapa envolve a análise e isolamento das frações $\mathrm{ALDH}^{+}$em células com expressão diminuída desses mesmos miRNAs;

- Realização de ensaios funcionais (proliferação, resistência à apoptose e migração/invasão) envolvendo células com expressão diminuída (referidas acima);

- Identificação dos genes-alvo regulados pelos miRNAs através de sequenciamento em larga-escala após a superexpressão ou a redução da expressão de miR-221, -222, 4728-3p nas células de interesse. 


\section{REFERÊNCIAS}

AL-EJEH, F. et al. Breast cancer stem cells: treatment resistance and therapeutic opportunities. Carcinogenesis, v. 32, n. 5, p. 650-658, 2011.

AL-HAJJ, M. Cancer stem cells and oncology therapeutics. Curr. Opin. Oncol., v. 19, n. 1, p. 61-64, 2007.

AL-HAJJ, M.; CLARKE, M. F. Self-renewal and solid tumor stem cells. Oncogene, v. 23, n. 43, p. 7274-7282, 2004.

AL-HAJJ, M. et al. Prospective identification of tumorigenic breast cancer cells. Proc. Natl. Acad. Sci. USA, v. 100, n. 7, p. 3983-3988, 2003.

ALISON, M. R. et al. Finding cancer stem cells: are aldehyde dehydrogenases fit for purpose? J. Pathol., v. 222, n. 4, p. 335-344, 2010.

ANDORFER, C. A. et al. MicroRNA signatures: clinical biomarkers for the diagnosis and treatment of breast cancer. Trends. Mol. Med., v. 17, n. 6, p. 313-319, 2011.

ANDROUTSELLIS-THEOTOKIS, A. et al. Notch signalling regulates stem cell numbers in vitro and in vivo. Nature, v. 442, n. 7104, p. 823-826, 2006.

ANDRÉ, S.; TOMÁS, A. R.; FONSECA, R. Determination of HER2 by fluorescence in situ hybridization (FISH) in breast cancer. Experience of the Reference Laboratory of Lisbon. Acta Med. Port., v. 18, n. 6, p. 417-422, 2005.

ARMSTRONG, L. et al. Phenotypic characterization of murine primitive hematopoietic progenitor cells isolated on basis of aldehyde dehydrogenase activity. Stem Cells, v. 22, n. 7, p. 1142-1151, 2004.

ATLASI, Y. et al. OCT-4, an embryonic stem cell marker, is highly expressed in bladder cancer. Int. J. Cancer, v. 120, n. 7, p. 1598-1602, 2007.

AUSTIN, T. W. et al. A role for the Wnt gene family in hematopoiesis: expansion of multilineage progenitor cells. Blood, v. 89, n. 10, p. 3624-3635, 1997.

BABAIE, Y. et al. Analysis of Oct4-dependent transcriptional networks regulating selfrenewal and pluripotency in human embryonic stem cells. Stem Cells, v. 25, n. 2, p. 500-510, 2007.

BAEK, D. et al. The impact of microRNAs on protein output. Nature, v. 455, n. 7209, p. 6471, 2008.

\footnotetext{
* De acordo com: ASSOCIAÇÃO BRASILEIRA DE NORMAS TÉCNICAS. NBR 6023: informação e documentação: referências: elaboração. Rio de Janeiro, 2002.
} 
BALBER, A. E. Concise review: aldehyde dehydrogenase bright stem and progenitor cell populations from normal tissues: characteristics, activities, and emerging uses in regenerative medicine. Stem Cells, v. 29, n. 4, p. 570-575, 2011.

BALZER, E. et al. LIN28 alters cell fate succession and acts independently of the let-7 microRNA during neurogliogenesis in vitro. Development, v. 137, n. 6, p. 891-900, 2010.

BARTEL, D. P. MicroRNAs: genomics, biogenesis, mechanism, and function. Cell, v. 116, n. 2, p. 281-297, 2004.

BEDARD, P. L.; CARDOSO, F.; PICCART-GEBHART, M. J. Stemming resistance to HER2 targeted therapy. J. Mammary Gland. Biol. Neoplasia, v. 14, n. 1, p. 55-66, 2009.

BELTRAN, A. S. et al. Generation of tumor-initiating cells by exogenous delivery of OCT4 transcription factor. Breast Cancer Res., v. 13, n. 5, p. R94, 2011.

BEN-PORATH, I., et al. An embryonic stem cell-like gene expression signature in poorly differentiated aggressive human tumors. Nature Genetics, v. 40, n. 5; p. 499-507, 2008.

BHARDWAJ, G. et al. Sonic hedgehog induces the proliferation of primitive human hematopoietic cells via BMP regulation. Nat. Immunol., v. 2, n. 2, p. 172-180, 2001.

BIXBY, S. et al. Cell-intrinsic differences between stem cells from different regions of the peripheral nervous system regulate the generation of neural diversity. Neuron., v. 35, n. 4, p. 643-656, 2002.

BONCI, D. et al. 'Advanced' generation lentiviruses as efficient vectors for cardiomyocyte gene transduction in vitro and in vivo. Gene. Ther., v. 10, n. 8, p. 630-636, 2003.

BONNET, D.; DICK, J. E. Human acute myeloid leukemia is organized as a hierarchy that originates from a primitive hematopoietic cell. Nat. Med., v. 3, n. 7, p. 730-737,1997.

BRACKEN, C. P. et al. The role of microRNAs in metastasis and epithelial-mesenchymal transition. Cell Mol. Life Sci., v. 66, n. 10, p. 1682-1699, 2009.

BURNS, J. C. et al. Vesicular stomatitis virus G glycoprotein pseudotyped retroviral vectors: concentration to very high titer and efficient gene transfer into mammalian and nonmammalian cells. Proc. Natl. Acad. Sci. USA, v. 90, n. 17, p. 8033-8037, 1993.

CALIN, G. A. et al. Frequent deletions and down-regulation of micro- RNA genes miR15 and miR16 at 13q14 in chronic lymphocytic leukemia. Proc. Natl. Acad. Sci. USA, v. 99, n. 24, p. 15524-15529, 2002.

CHAKRABARTY, A. Trastuzumab-resistant cells rely on a HER2-PI3K-FoxO-survivin axis and are sensitive to PI3K inhibitors. Cancer Res., v.73, n. 3, p.1190-1200, 2013.

CHARAFE-JAUFFRET, E. et al. Breast cancer cell lines contain functional cancer stem cells with metastatic capacity and a distinct molecular signature. Cancer. Res., v. 69, n. 4, p. 13021313, 2009. 
CHRISTGEN, M. et al. Identification of a distinct side population of cancer cells in the Cal51 human breast carcinoma cell line. Mol. Cell. Biochem., v. 306, n. 1-2, p. 201-212, 2007.

CHUTE, J. P. et al. Inhibition of aldehyde dehydrogenase and retinoid signaling induces the expansion of human hematopoietic stem cells. Proc. Natl. Acad. Sci. USA, v. 103, n. 31, p. 11707-11712, 2006.

CLARKE, M. F.; FULLER, M. Stem cells and cancer: two faces of eve. Cell, v. 124, n. 6, p. 1111-1115, 2006.

COLLINS, A. T. et al. Prospective identification of tumorigenic prostate cancer stem cells. Cancer Res., v. 65, n. 23, p. 10946-10951, 2005.

COLLINS, S. J. Retinoic acid receptors, hematopoiesis and leukemogenesis. Curr. Opin. Hematol., v. 15, n. 4, p. 346-351, 2008.

COOLS, M. et al. Gonadoblastoma arising in undifferentiated gonadal tissue within dysgenetic gonads. J. Clin. Endocrinol. Metab., v. 91, n. 6, p. 2404-2413, 2006.

CREIGHTON, C. J. et al. Residual breast cancers after conventional therapy display mesenchymal as well as tumor-initiating features. Proc. Natl. Acad. Sci. USA, v. 106, n. 33, p. $13820-13825,2009$.

D'ANGELO, R. C.; WICHA, M. S. Stem cells in normal development and cancer. Prog. Mol. Biol. Transl. Sci., v. 95, p. 113-158, 2010.

DAVOREN, P. A. et al. Identification of suitable endogenous control genes for microRNA gene expression analysis in human breast cancer. BMC Mol. Biol., v. 9, p. 76, 2008.

DE BEÇA, F.F. et al. Cancer stem cells markers CD44, CD24 and ALDH1 in breast cancer special histological types. J. Clin. Pathol., v. 66, n. 3, p. 187-191, 2013.

DEAN, M.; FOJO, T.; BATES, S. Tumour stem cells and drug resistance. Nat. Ver. Cancer, v. 5, n. 4, p. 275-284, 2005.

DEBEB, B. G. et al. Differential radiosensitizing effect of valproic acid in differentiation versus self-renewal promoting culture conditions. Int. J. Radiat. Oncol. Biol. Phys., v. 76, n. 3, p. 889-895, 2010.

DONTU, G. et al. In vitro propagation and transcriptional profiling of human mammary stem/progenitor cells. Genes Dev., v. 17, n. 10, p. 1253-1270, 2003.

DONTU, G.; WICHA, M. S. Survival of mammary stem cells in suspension culture: implications for stem cell biology and neoplasia. J. Mammary Gland. Biol. Neoplasia, v. 10, n. 1, p. 75-86, 2005.

DUELLMAN, S. J. et al. A bioluminescence assay for aldehyde dehydrogenase activity. Anal Biochem., v. 434, n. 2, p. 226-232, 2013. 
DUESTER, G. Families of retinoid dehydrogenases regulating vitamin A function: production of visual pigment and retinoic acid. Eur. J. Biochem., v. 267, n. 14, p. 4315-4324, 2000 .

EISTERER, W. et al. Different subsets of primary chronic myeloid leukemia stem cells engraft immunodeficient mice and produce a model of the human disease. Leukemia, v. 19, n. 3, p. 435-441, 2005.

ELSTON, C. W.; ELLIS, I. O. Pathological prognostic factors in breast cancer. I. The value of histological grade in breast cancer: experience from a large study with long-term followup. Histopathology, v. 19, n. 5, p. 403-410, 1991.

EVANS, R. M. The steroid and thyroid hormone receptor superfamily. Science, v. 240, n. 4854, p. 889-895, 1988.

EZEH, U. I. et al. Human embryonic stem cell genes OCT4, NANOG, STELLAR, and GDF3 are expressed in both seminoma and breast carcinoma. Cancer, v. 104, n. 10, p. 2255-2265, 2005.

FANG, D. et al. A tumorigenic subpopulation with stem cell properties in melanomas. Cancer Res., v. 65, n. 20, p. 9328-9337, 2005.

FARNIE, G. et al. Novel cell culture technique for primary ductal carcinoma in situ: role of Notch and epidermal growth factor receptor signaling pathways. J. Natl. Cancer Inst., v. 99, n. 8, p. 616-627, 2007.

FEDERICO, M. Methods in Molecular Biology. v. 229. Lentivirus gene engineering protocols. New York City: Humana Press, 2003.

FELLI, N. et al. MicroRNAs 221 and 222 inhibit normal erythropoiesis and erythroleukemic cell growth via kit receptor down-modulation. Proc. Natl. Acad. Sci. USA, v. 102, n. 50, p. 18081-18086, 2005.

FELICETTI, F. The promyelocytic leukemia zinc finger-microRNA-221/-222 pathway controls melanoma progression through multiple oncogenic mechanisms. Cancer Res., v. 68, n. 8 , p. $2745-2754,2008$.

FILLMORE, C. M.; KUPERWASSER, C. Human breast cancer cell lines contain stem-like cells that self-renew, give rise to phenotypically diverse progeny and survive chemotherapy. Breast Cancer Res., v. 10, n. 2, p. R25, 2008.

FRAME, F. M.; MAITLAND, N. J. Cancer stem cells, models of study and implications of therapy resistance mechanisms. Adv. Exp. Med. Biol., v. 720, p. 105-118, 2011.

GALARDI, S. et al. miR-221 and miR-222 expression affects the proliferation potential of human prostate carcinoma cell lines by targeting p27Kip1. J. Biol. Chem., v. 282, n. 32, p. 23716-23724, 2007. 
GEE, H. E. et al. The small-nucleolar RNAs commonly used for microRNA normalisation correlate with tumour pathology and prognosis. Br. J. Cancer, v. 104, n. 7, p. 1168-1177, 2011.

GENTRY, T. et al. Isolation of early hematopoietic cells, including megakaryocyte progenitors, in the ALDH-bright cell population of cryopreserved, banked UC blood. Cytotherapy, v. 9, n. 6, p. 569-576, 2007.

GEOGGOULIAS, V. et al. Trastuzumab decreases the incidence of clinical relapses in patients with early breast cancer presenting chemo- therapy-resistant CK19 mRNA-positive circulating tumor cells: results of a randomized phase II study. Ann. Oncol., v. 23, n. 7, p. 1744-1750, 2012.

GIBBS, C. P. et al. Stem-like cells in bone sarcomas: implications for tumorigenesis. Neoplasia, v. 7, n. 11, p. 967-976, 2005.

GINESTIER, C. et al. ALDH1 is a marker of normal and malignant human mammary stem cells and a predictor of poor clinical outcome. Cell Stem Cell, v. 1, n. 5, p. 555-567, 2007.

GLINSKY, G. V. Stem cell origin of death-from-cancer phenotypes of human prostate and breast cancers. Stem Cell Rev., v. 3, n. 1, p. 79-93, 2007.

GONG, C. et al. Up-regulation of miR-21 mediates resistance to trastuzumab therapy for breast cancer. J. Biol. Chem., v. 286, n. 21, p. 19127-19137, 2011.

GREGORY, P. A. et al. The miR-200 family and miR-205 regulate epithelial to mesenchymal transition by targeting ZEB1 and SIP1. Nat. Cell Biol., v. 10, n. 5, p. 593-601, 2008.

GU, G. et al. Prostate cancer cells with stem cell characteristics reconstitute the original human tumor in vivo. Cancer Res., v. 67, n. 10, p. 4807-4815, 2007.

GUO, L.; LU, Z. The fate of miRNA strand through evolutionary analysis: implication for degradation as merely carrier strand or potential regulatory molecule? PLoS One, v. 5, n. 6, p. e11387, 2010.

HARRIS, L. N. et al. Predictors of resistance to preoperative trastuzumab and vinorelbine for HER2-positive early breast cancer. Clin. Cancer Res., v. 13, n. 4, p. 1198-1207, 2007.

HE, L.; HANNON, G. J. MicroRNAs: small RNAs with a big role in gene regulation. Nat Rev. Genet., v. 5, n. 7, p. 522-531, 2004.

HEISER, W. C. Delivery of DNA to cells in culture using particle bombardment. Methods Mol. Biol., v. 245, p. 175-184, 2004.

HESS, D. A. et al. Functional characterization of highly purified human hematopoietic repopulating cells isolated according to aldehyde dehydrogenase activity. Blood, v. 104, n. 6, p. 1648-1655, 2004. 
HESS, D. A. et al. Selection based on CD133 and high aldehyde dehydrogenase activity isolates long-term reconstituting human hematopoietic stem cells. Blood, v. 107, n. 5, p. 2162-2169, 2006.

HONETH, G. et al. The CD44+/CD24- phenotype is enriched in basal-like breast tumors. Breast Cancer Res., v. 10, n. 3, p. R53, 2008.

HOPE, K. J.; JIN, L.; DICK, J. E. Acute myeloid leukemia originates from a hierarchy of leukemic stem cell classes that differ in self-renewal capacity. Nat. Immunol., v. 5, n. 7, p. 738-743, 2004.

HOUBAVIY, H.B.; MURRAY, M.F.; SHARP, P.A. Embryonic stem cell-specific microRNAs. Dev. Cell., v. 5, n. 2, p. 351-358, 2003.

$\mathrm{HU}$, T. et al. Octamer 4 small interfering RNA results in cancer stem cell-like cell apoptosis. Cancer Res., v. 68, n. 16, p. 6533-6540, 2008.

HU, Y.; FU, L. Targeting cancer stem cells: a new therapy to cure cancer patients. Am. J. Cancer Res., v. 2, n. 3, p. 340-356, 2012.

HUANG, Q. et al. The microRNAs miR-373 and miR-520c promote tumour invasion and metastasis. Nat. Cell Biol., v. 10, n. 2, p. 202-210, 2008.

HYNES, N. E.; LANE, H. A. ERBB receptors and cancer: the complexity of targeted inhibitors. Nat. Rev. Cancer, v. 5, n. 5, p. 341-354, 2005.

HYNES, N. E.; MACDONALD, G. ErbB receptors and signaling pathways in cancer. Curr. Opin. Cell Biol., v. 21, n. 2, p. 177-184, 2009.

IARC. World Cancer Report, 2008. Disponível em: http://www.iarc.fr/en/publications/pdfsonline/wcr/2008/wcr_2008.pdf. Acesso em: 05 de Maio de 2013.

ISAACS, J.T. Role of programmed cell death in carcinogenesis. Environ. Health Perspect., v. 101, suppl. 5, p. 27-34, 1993.

ITHIMAKIN, S. et al. HER2 drives luminal breast cancer stem cells in the absence of HER2 amplification: implications for efficacy of adjuvant trastuzumab. Cancer Res., v. 73 n. 5, p. 1635-1646, 2013.

IORIO, M. V. et al. MicroRNA gene expression deregulation in human breast cancer. Cancer Res., v. 65, p. 7065-7070, 2005.

IZUMI, Y. et al. Tumour biology: herceptin acts as an anti-angiogenic cocktail. Nature, v. 416, n. 6878, p. 279-280, 2002.

JAISWAL, S. et al. Expression of BCR/ABL and BCL-2 in myeloid progenitors leads to myeloid leukemias. Proc. Natl. Acad. Sci. USA, v. 100, n. 17, p. 10002-10007, 2003.

JAMIESON, C. H. et al. Granulocyte-macrophage progenitors as candidate leukemic stem cells in blast-crisis CML. N. Engl. J. Med., v. 351, n. 7, p. 657-667, 2004. 
JIANG, F. et al. Aldehyde dehydrogenase 1 is a tumor stem cell-associated marker in lung cancer. Mol. Cancer Res., v. 7, n. 3, p. 330-338, 2009.

JIN, X., et al. Aldehyde dehydrogenase 1 can be used as a new marker of cancer stem cells in laryngeal cancer cells in vitro. Zhonghua Zhong Liu Za Zhi., v. 33, n. 12, p. 900-904, 2011.

KANG, L. et al. A positive cross-regulation of HER2 and ER- $\alpha 36$ controls ALDH1 positive breast cancer cells. J. Steroid Biochem. Mol. Biol., v. 127, n. 3-5, p. 262-268, 2011.

KELLY, L. M.; GILLILAND, D. G. Genetics of myeloid leukemias. Annu. Rev. Genomics Hum. Genet., v. 3, p. 179-198, 2002.

KHEIRELSEID, E. A. et al. Identification of endogenous control genes for normalisation of real-time quantitative PCR data in colorectal cancer. BMC Mol Biol, v. 11, p. 12, 2010.

KIM, S. J. et al. MicroRNA let-7a suppresses breast cancer cell migration and invasion through downregulation of C-C chemokine receptor type 7. Breast Cancer Res., v. 14, n. 1, p. R14, 2012.

KONDO, T.; SETOGUCHI, T.; TAGA, T. Persistence of a small subpopulation of cancer stem-like cells in the C6 glioma cell line. Proc. Natl. Acad. Sci. USA, v. 101, n. 3, p. 781786, 2004.

KORKAYA, H. et al. HER2 regulates the mammary stem/progenitor cell population driving tumorigenesis and invasion. Oncogene, v. 27, n. 47, p. 6120-6130, 2008.

KOYAMA, Y. et al. In vivo molecular imaging to diagnose and subtype tumors through receptor-targeted optically labeled monoclonal antibodies. Neoplasia, v. 9, n. 12, p. 10211029, 2007.

KRIVTSOV, A. V. et al. Transformation from committed progenitor to leukaemia stem cell initiated by MLL-AF9. Nature, v. 442, n. 7104, p. 818-822, 2006.

KRIZHANOVSKY, V.; LOWE, S. W. Stem cells: The promises and perils of p53. Nature, v. 460, n. 7259, p. 1085-1086, 2009.

KWON, M. J.; SHIN, Y. K. Regulation of ovarian cancer stem cells or tumor-initiating cells. Int. J. Mol. Sci., v. 14, n. 4, p. 6624-6648, 2013.

LABRECQUE, J.; BHAT, P. V.; LACROIX, A. Purification and partial characterization of a rat kidney aldehyde dehydrogenase that oxidizes retinal to retinoic acid. Biochem. Cell Biol., v. 71, n. 1-2, p. 85-89, 1993.

LE SAGE, C. et al. Regulation of the p27(Kip1) tumor suppressor by miR-221 and miR-222 promotes cancer cell proliferation. EMBO J., v. 26, n. 15, p. 3699-3708, 2007.

LEIS, O. et al. Sox 2 expression in breast tumours and activation in breast cancer stem cells. Oncogene, v. 31, n. 11, p. 1354-1365, Mar 2012. 
LI, C. et al. Identification of pancreatic cancer stem cells. Cancer Res, v. 67, n. 3, p. 1030$107,2007$.

LI, X. et al. Intrinsic resistance of tumorigenic breast cancer cells to chemotherapy. J. Natl. Cancer Inst., v. 100, n. 9, p. 672-679, 2008.

LI, T., et al. ALDH1A1 is a marker for malignant prostate stem cells and predictor of prostate cancer patients' outcome. Lab. Invest., v. 90, n. 2, p. 234-244, 2010.

LIANG, D., SHI, Y. Aldehyde dehydrogenase-1 is a specific marker for stem cells in human lung adenocarcinoma. Med. Oncol., v. 29, n. 2, p. 633-639, 2012.

LIU, S. et al. Hedgehog signaling and Bmi-1 regulate self-renewal of normal and malignant human mammary stem cells. Cancer Res., v. 66, n. 12, p. 6063-6071, 2006.

LIU, S.; WICHA, M. S. Targeting breast cancer stem cells. J. Clin. Oncol., v. 28, n. 25, p. 4006-4012, 2010.

LOHBERGER, B., et al. Aldehyde dehydrogenase 1, a potential marker for cancer stem cells in human sarcoma. PLoS One, v. 7, n. 8, e43664, 2012.

LOWE, S. W.; LIN, A. W. Apoptosis in cancer. Carcinogenesis, v. 21, n. 3, p. 485-495, 2000 .

LU, J. et al. MicroRNA expression profiles classify human cancers. Nature, v. 435, n. 7043, p. 834-838, 2005.

LU, Y. et al. Insulin-like growth factor-I receptor signaling and resistance to trastuzumab (Herceptin). J. Natl. Cancer Inst., v. 93, n. 24, p. 1852-1857, 2001.

LYNCH, M. D.; CARIATI, M.; PURUSHOTHAM, A. D. Breast cancer, stem cells and prospects for therapy. Breast Cancer Res., v. 8, n. 3, p. 211, 2006.

MA, I.; ALLAN, A. L. The role of human aldehyde dehydrogenase in normal and cancer stem cells. Stem Cell Rev., v. 7, n. 2, p. 292-306, 2011.

MA, L.; TERUYA-FELDSTEIN, J.; WEINBERG, R. A. Tumour invasion and metastasis initiated by microRNA-10b in breast cancer. Nature, v. 449, n. 7163, p. 682-688, 2007.

MACHIDA, C.A. Methods and Protocols. New York City: Humana Press, 2003.

MAGNI, M. et al. Induction of cyclophosphamide-resistance by aldehyde-dehydrogenase gene transfer. Blood, v. 87, n. 3, p. 1097-1103, 1996.

MAGNIFICO, A. et al. Tumor-initiating cells of HER2-positive carcinoma cell lines express the highest oncoprotein levels and are sensitive to trastuzumab. Clin. Cancer Res., v. 15, n. 6, p. 2010-2021, 2009.

MANI, S. A. et al. The epithelial-mesenchymal transition generates cells with properties of stem cells. Cell, v. 133, n. 4, p. 704-715, 2008. 
MARCHITTI, S. A. et al. Non-P450 aldehyde oxidizing enzymes: the aldehyde dehydrogenase superfamily. Expert Opin. Drug Metab. Toxicol., v. 4, n. 6, p. 697-720, 2008 .

MATSUI, W. et al. Characterization of clonogenic multiple myeloma cells. Blood, v. 103, n. 6, p. 2332-2336, 2004.

MCNEILL, R. E.; MILLER, N.; KERIN, M. J. Evaluation and validation of candidate endogenous control genes for real-time quantitative PCR studies of breast cancer. BMC Mol. Biol., v. 8, p. 107, 2007.

MEDINA, R. et al. MicroRNAs 221 and 222 bypass quiescence and compromise cell survival. Cancer Res., v. 68, n. 8, p. 2773-80, 2008.

MESHORER, E. et al. Hyperdynamic plasticity of chromatin proteins in pluripotent embryonic stem cells. Dev. Cell, v. 10, n. 1, p. 105-116, 2006.

MILLER, A. D.; CHEN, F. Retrovirus packaging cells based on 10A1 murine leukemia virus for production of vectors that use multiple receptors for cell entry. J. Virol., v. 70, n. 8, p. 5564-5571, 1996.

MIRBASE. Browse miRBase by species: Release 19, 2012. Disponível em: $<$ http://www.mirbase.org/cgi-bin/browse.pl?org=hsa> . Acesso em: 01 de Jun 2013.

MOASSER, M. M. The oncogene HER2: its signaling and transforming functions and its role in human cancer pathogenesis. Oncogene, v. 26, n. 45, p. 6469-6487, 2007.

MOLOFSKY, A. V.; PARDAL, R.; MORRISON, S. J. Diverse mechanisms regulate stem cell self-renewal. Curr. Opin. Cell Biol., v. 16, n. 6, p. 700-707, 2004.

MOREB, J. S. Aldehyde dehydrogenase as a marker for stem cells. Curr. Stem Cell Res. Ther., v. 3, n. 4 p. 237-246, 2008.

MORIMOTO, K. et al. Stem cell marker aldehyde dehydrogenase 1-positive breast cancers are characterized by negative estrogen receptor, positive human epidermal growth factor receptor type 2, and high Ki67 expression. Cancer Sci., v. 100, n. 6, p. 1062-1068, 2009.

MUROHASHI, M. et al. Gene set enrichment analysis provides insight into novel signalling pathways in breast cancer stem cells. Br. J. Cancer, v. 102, n. 1, p. 206-12, 2010.

NAHTA, R.; ESTEVA, F. J. HER2 therapy: molecular mechanisms of trastuzumab resistance. Breast Cancer Res., v. 8, n. 6, p. 215, 2006.

NAKSHATRI, H.; SROUR, E. F.; BADVE, S. Breast cancer stem cells and intrinsic subtypes: controversies rage on. Curr. Stem Cell Res. Ther., v. 4, n. 1, p. 50-60, 2009.

NASSIRPOUR, R., et al. miR-221 Promotes Tumorigenesis in Human Triple Negative Breast Cancer Cells. PLoS One, v. 8, n. 4, in press, 2013. 
NG, E. K. et al. Circulating microRNAs as specific biomarkers for breast cancer detection. PLoS One, v. 8, n. 1, p. e53141, 2013.

NICHOLS, J. et al. Formation of pluripotent stem cells in the mammalian embryo depends on the POU transcription factor Oct4. Cell, v. 95, n. 3, p. 379-391, 1998.

NICOLINI, A. et al. Stem cells: their role in breast cancer development and resistance to treatment. Curr. Pharm. Biotechnol., v. 12, n. 2, p. 196-205, 2011.

NIWA, H.; MIYAZAKI, J.; SMITH, A. G. Quantitative expression of Oct-3/4 defines differentiation, dedifferentiation or self-renewal of ES cells. Nat. Genet., v. 24, n. 4, p. 372$376,2000$.

O'BRIEN, C. A. et al. A human colon cancer cell capable of initiating tumour growth in immunodeficient mice. Nature, v. 445, n. 7123, p. 106-110, 2007.

OAK, P. S. et al. Combinatorial treatment of mammospheres with trastuzumab and salinomycin efficiently targets HER2-positive cancer cells and cancer stem cells. Int J Cancer, v. 131, n. 12, p. 2808-2819, 2012.

OLIVERAS-FERRAROS, C. et al. Pathway-focused proteomic signatures in HER2overexpressing breast cancer with a basal-like phenotype: new insights into de novo resistance to trastuzumab (Herceptin). Int. J. Oncol., v. 37, n. 3, p. 669-678, 2010.

OZBEK, E., et al. Stem cell markers aldehyde dehydrogenase type 1 and nestin expressions in renal cell cancer. Arch. Ital. Urol. Androl., v. 84, n. 1, p. 7-11, 2012.

PAIK, S.; KIM, C.; WOLMARK, N. HER2 status and benefit from adjuvant trastuzumab in breast cancer. N. Engl. J. Med., v. 358, n. 13, p. 1409-1411, 2008.

PANDOLFI, P. P. Breast cancer--loss of PTEN predicts resistance to treatment. N. Engl. J. Med., v. 351, n. 22, p. 2337-2338, 2004.

PARDAL, R.; CLARKE, M. F.; MORRISON, S. J. Applying the principles of stem-cell biology to cancer. Nat. Rev. Cancer, v. 3, n. 12, p. 895-902, 2003.

PASSEGUÉ, E. et al. Normal and leukemic hematopoiesis: are leukemias a stem cell disorder or a reacquisition of stem cell characteristics? Proc. Natl. Acad. Sci. USA, v. 100 Suppl. 1, p. 11842-11849, 2003.

PEARCE, D. J. et al. Characterization of cells with a high aldehyde dehydrogenase activity from cord blood and acute myeloid leukemia samples. Stem Cells, v. 23, n. 6, p. 752-760, 2005.

PENG, S.; MAIHLE, N. J.; HUANG, Y. Pluripotency factors Lin28 and Oct4 identify a subpopulation of stem cell-like cells in ovarian cancer. Oncogene, v. 29, n. 14, p. 2153-2159, 2010.

PEREZ, E. A. et al. HER2 and chromosome 17 effect on patient outcome in the N9831 adjuvant trastuzumab trial. J. Clin. Oncol., v. 28, n. 28, 4307-4315, 2010. 
PEROU, C. M. et al. Molecular portraits of human breast tumours. Nature, v. 406, n. 6797, p. 747-752, 2000.

PERSSON, H. et al. Identification of new microRNAs in paired normal and tumor breast tissue suggests a dual role for the ERBB2/Her2 gene. Cancer Res., v. 71, n. 1, p. 78-86, 2011.

PHILLIPS, T. M.; MCBRIDE, W. H.; PAJONK, F. The response of CD24(-/low)/CD44+ breast cancer-initiating cells to radiation. J. Natl. Cancer Inst., v. 98, n. 24, p. 1777-1785, 2006.

PICCART-GEBHART, M. J. et al. Trastuzumab after adjuvant chemotherapy in HER2positive breast cancer. N. Engl. J. Med., v. 353, n. 16, p. 1659-1672, 2005.

PINEAU, P. et al. miR-221 overexpression contributes to liver tumorigenesis. Proc. Natl. Acad. Sci. USA, v. 107, n 1, p. 264-269, 2010.

POESCHLA, E. M. Non-primate lentiviral vectors. Curr. Opin. Mol. Ther, v. 5, n. 5, p. 529-540, 2003.

POLANOVSKI, O. L.; LEBEDENKO, E. N.; DEYEV, S. M. ERBB oncogene proteins as targets for monoclonal antibodies. Biochemistry (Mosc), v. 77, n. 3, p. 227-245, 2012.

POLYAK, K.; HAHN, W. C. Roots and stems: stem cells in cancer. Nat. Med., v. 12, n. 3, p. 296-300, 2006.

PONTI, D. et al. Isolation and in vitro propagation of tumorigenic breast cancer cells with stem/progenitor cell properties. Cancer Res., v. 65, n. 13, p. 5506-5511, 2005.

PRAT, A. et al. Phenotypic and molecular characterization of the claudin-low intrinsic subtype of breast cancer. Breast Cancer Res., v. 12, n. 5, p. R68, 2010.

PRINCE, M. E. et al. Identification of a subpopulation of cells with cancer stem cell properties in head and neck squamous cell carcinoma. Proc. Natl. Acad. Sci. USA, v. 104, n. 3, p. 973-978, 2007.

PRUD'HOMME, G. J. et al. Breast cancer stem-like cells are inhibited by a non-toxic aryl hydrocarbon receptor agonist. PLoS One, v. 5, n. 11, p. e13831, 2010.

PÁLYI-KREKK, Z. et al. Hyaluronan-induced masking of ErbB2 and CD44-enhanced trastuzumab internalisation in trastuzumab resistant breast cancer. Eur. J. Cancer, v. 43, n. 16, p. 2423-2433, 2007.

REYA, T. et al. Stem cells, cancer, and cancer stem cells. Nature, v. 414, n. 6859, p. 105$111,2001$.

REYNOLDS, B.A.; WEISS, S. Clonal and population analyses demonstrate that an EGFresponsive mammalian embryonic CNS precursor is a stem cell. Dev. Biol., v. 175, n. 1, p. $1-13,1996$. 
RICARDO, S. et al. Breast cancer stem cell markers CD44, CD24 and ALDH1: expression distribution within intrinsic molecular subtype. J. Clin. Pathol., v. 64, n. 11, p. 937-946, 2011.

RICCI-VITIANI, L. et al. Identification and expansion of human colon-cancer-initiating cells. Nature, v. 445, n. 7123, p. 111-115, 2007.

RICCI-VITIANI, L. et al. Absence of caspase 8 and high expression of PED protect primitive neural cells from cell death. J. Exp. Med., v. 200, n. 10, p. 1257-1266, 2004.

ROLLINS-RAVAL, M.A., et al. ALDH, CA I, and CD2AP: Novel, Diagnostically Useful Immunohistochemical Markers to Identify Erythroid Precursors in Bone Marrow Biopsy Specimens. Am. J. Clin. Pathol., v. 137, n. 1, p. 30-38, 2012.

ROBERTSON, F. M. et al. Imaging and analysis of 3D tumor spheroids enriched for a cancer stem cell phenotype. J. Biomol. Screen, v. 15, n. 7, p. 820-9, 2010.

RODRIGUEZ-PINILLA, S. M. et al. Sox2: a possible driver of the basal-like phenotype in sporadic breast cancer. Mod. Pathol., v. 20, n. 4, p. 474-81, 2007.

ROESLER, R. et al. HER2 as a cancer stem-cell target. Lancet Oncol., v. 11, n. 3, p. 225$226,2010$.

ROMOND, E. H. et al. Trastuzumab plus adjuvant chemotherapy for operable HER2-positive breast cancer. N. Engl. J. Med., v. 353, n. 16, p. 1673-1684, 2005.

ROSS, J. S. et al. The Her-2/neu gene and protein in breast cancer 2003: biomarker and target of therapy. Oncologist, v. 8, n. 4, p. 307-325, 2003.

RUVKUN, G. Clarifications on miRNA and cancer. Science, v. 311, n. 5757, p. 36-37, 2006.

SAHOVIC, E.A., Role for aldehyde dehydrogenase in survival of progenitors for murine blast cell colonies after treatment with 4-hydroperoxycyclophosphamide in vitro. Cancer Res., v. 48, n. 5, p.1223-1226, 1988.

SANADA, Y. et al. Histopathologic evaluation of stepwise progression of pancreatic carcinoma with immunohistochemical analysis of gastric epithelial transcription factor SOX2: comparison of expression patterns between invasive components and cancerous or nonneoplastic intraductal components. Pancreas, v. 32, n. 2, p. 164-170, 2006.

SBI (System Biosciences) [internet]. Mountain View. Human and Mouse Lenti-miR TM MicroRNA Precursor Clone Collections (2010). Disponível em: $<$ http://www.systembio.com/microrna-research/microrna-overexpression $>$. Acesso em 06 de Maio de 2013.

SEIDMAN, A. D. et al. Weekly trastuzumab and paclitaxel therapy for metastatic breast cancer with analysis of efficacy by HER2 immunophenotype and gene amplification. J Clin Oncol., v. 19, n. 10, p. 2587-2595, 2001. 
SELL, S. Stem cell origin of cancer and differentiation therapy. Crit. Rev. Oncol. Hematol., v. 51, n. 1, p. 1-28, 2004.

SEMPERE, L. F. et al. Altered MicroRNA expression confined to specific epithelial cell subpopulations in breast cancer. Cancer Res., v. 67, n. 24, p. 11612-11620, 2007.

SETOGUCHI, T.; TAGA, T.; KONDO, T. Cancer stem cells persist in many cancer cell lines. Cell Cycle, v. 3, n. 4, p. 414-415, 2004.

SHAH, M.Y.; CALIN, G.A. MicroRNAs miR-221 and miR-222: a new level of regulation in aggressive breast cancer. Genome Med., v. 3, n. 8, p. 56, 2011.

SHIMONO, Y. et al. Downregulation of miRNA-200c links breast cancer stem cells with normal stem cells. Cell, v. 138, n. 3, p. 592-603, 2009.

SIDDIQA, A. et al. Expression of HER-2 in MCF-7 breast cancer cells modulates antiapoptotic proteins Survivin and Bcl-2 via the extracellular signal-related kinase (ERK) and phosphoinositide-3 kinase (PI3K) signalling pathways. BMC Cancer, v. 8, p. 129, 2008.

SINGH, S. K. et al. Cancer stem cells in nervous system tumors. Oncogene, v. 23, n. 43, p. 7267-7273, 2004a.

SINGH, S. K. et al. Identification of human brain tumour initiating cells. Nature, v. 432, n. 7015, p. 396-401, 2004b.

SINGH, A.; SETTLEMAN, J. EMT, cancer stem cells and drug resistance: an emerging axis of evil in the war on cancer. Oncogene, v. 29, n. 34, p. 4741-4751, 2010.

SLAMON, D. J. et al. Human breast cancer: correlation of relapse and survival with amplification of the HER-2/neu oncogene. Science, v. 235, n. 4785, p. 177-182, 1987.

SLAMON, D. J. et al. Use of chemotherapy plus a monoclonal antibody against HER2 for metastatic breast cancer that overexpresses HER2. N. Engl. J. Med., v. 344, n. 11, p. 783792, 2001.

SLÁDEK, N. E. Human aldehyde dehydrogenases: potential pathological, pharmacological, and toxicological impact. J. Biochem. Mol. Toxicol., v. 17, n. 1, p. 7-23, 2003.

SO, E. N.; CROWE, D. L. Characterization of a retinoic acid responsive element in the human ets-1 promoter. IUBMB Life, v. 50, n. 6, p. 365-370, 2000.

SODROSKI, J.G. Vector containing HIV packaging sequences, packging defective HIV vectors, and uses thereof. US patent \#5,665,577. 1997.

SOPHOS, N. A.; VASILIOU, V. Aldehyde dehydrogenase gene superfamily: the 2002 update. Chem. Biol. Interact., v. 143-144, p. 5-22, 2003.

SORLIE, T. et al. Gene expression patterns of breast carcinomas distinguish tumor subclasses with clinical implications. Proc. Natl. Acad. Sci. USA, v. 98, n. 19, p. 10869-10874, 2001. 
SPINK, K. E.; POLAKIS, P.; WEIS, W. I. Structural basis of the Axin-adenomatous polyposis coli interaction. EMBO. J., v. 19, n. 10, p. 2270-2279, 2000.

STINSON, S. et al. TRPS1 targeting by miR-221/222 promotes the epithelial-tomesenchymal transition in breast cancer. Sci. Signal., v. 4; n. 177, p. ra41, 2011.

SUH, M. R. et al. Human embryonic stem cells express a unique set of microRNAs. Dev. Biol., v. 270, n. 2, p. 488-498, 2004.

TAI, M. H. et al. Oct4 expression in adult human stem cells: evidence in support of the stem cell theory of carcinogenesis. Carcinogenesis, v. 26, n. 2, p. 495-502, 2005.

TAIPALE, J.; BEACHY, P. A. The Hedgehog and Wnt signalling pathways in cancer. Nature, v. 411, n. 6835, p. 349-354, 2001.

VALASTYAN, S. et al. A pleiotropically acting microRNA, miR-31, inhibits breast cancer metastasis. Cell, v. 137, n. 6, p. 1032-1046, 2009.

VAN RHENEN, A. et al. High stem cell frequency in acute myeloid leukemia at diagnosis predicts high minimal residual disease and poor survival. Clin. Cancer Res., v. 11, n. 18, p. 6520-6527, 2005.

VAZQUEZ-MARTIN, A. et al. The anti-diabetic drug metformin suppresses the metastasisassociated protein CD24 in MDA-MB-468 triple-negative breast cancer cells. Oncol. Rep, v. 25, n. 1, p. 135-40, 2011.

VERMEULEN, L. et al. Cancer stem cells--old concepts, new insights. Cell Death Differ., v. 15, n. 6, p. 947-958, 2008.

VISONE, R. et al. MicroRNAs (miR)-221 and miR-222, both overexpressed in human thyroid papillary carcinomas, regulate p27Kip1 protein levels and cell cycle. Endocr. Relat. Cancer, v. 14, n. 3, p. 791-798, 2007.

VISWANATHAN, S. R.; DALEY, G. Q.; GREGORY, R. I. Selective blockade of microRNA processing by Lin28. Science, v. 320, n. 5872, p. 97-100, 2008.

VOGEL, C. L. et al. Efficacy and safety of trastuzumab as a single agent in first-line treatment of HER2-overexpressing metastatic breast cancer. J. Clin. Oncol., v. 20, n. 3, p. 719-726, 2002.

WAKAMATSU, Y., et al. Expression of cancer stem cell markers ALDH1, CD44 and CD133 in primary tumor and lymph node metastasis of gastric cancer. Pathol. Int., v. 62, n. 2, p. 112-119, 2012.

WANG, C., et al. Evaluation of CD44 and CD133 as cancer stem cell markers for colorectal cancer. Oncol. Rep., v. 28, n. 4, p. 1301-1308, 2012.

WEISSMAN, I. L. Normal and neoplastic stem cells. Novartis Found. Symp., v. 265, p. 35$50,2005$. 
WICHA, M.S., LIU S., DONTU, G. Cancer stem cells: An oldidea-A paradigm shift. Cancer Res., v. 66, n. 4, p. 1883-1890, 2006.

WOLFF, A. C. et al. American Society of Clinical Oncology/College of American Pathologists guideline recommendations for human epidermal growth factor receptor 2 testing in breast cancer. Arch. Pathol. Lab. Med., v. 131, n. 1, p. 18-43, 2007.

WU, A. et al. Aldehyde dehydrogenase 1, a functional marker for identifying cancer stem cells in human nasopharyngeal carcinoma. Cancer Lett., v. 330, n. 2, p. 181-189, 2013.

XI, R.; XIE, T. Stem cell self-renewal controlled by chromatin remodeling factors. Science, v. 310, n. 5753, p. 1487-1489, 2005.

YANG, X. et al. Double-negative feedback loop between reprogramming factor LIN28 and microRNA let-7 regulates aldehyde dehydrogenase 1-positive cancer stem cells. Cancer Res., v. 70, n. 22, p. 9463-9472, 2010.

YOSHIDA, A. et al. Human aldehyde dehydrogenase gene family. Eur. J. Biochem., v. 251, n. 3, p. 549-557, 1998.

YU, J. et al. Induced pluripotent stem cell lines derived from human somatic cells. Science, v. 318, n. 5858, p. 1917-1920, 2007.

YU, F. et al. let-7 regulates self renewal and tumorigenicity of breast cancer cells. Cell, v. 131, n. 6; p. 1109-1123, 2007.

ZHAO, J. J. et al. MicroRNA-221/222 negatively regulates estrogen receptor alpha and is associated with tamoxifen resistance in breast cancer. J. Biol. Chem., v. 283, n. 45, p. 3107931086, 2008.

ZHOU, M. et al. MicroRNA-125b confers the resistance of breast cancer cells to paclitaxel through suppression of pro-apoptotic Bcl-2 antagonist killer 1 (Bak1) expression. J. Biol. Chem., v. 285, n. 28; 21496-21507, 2010. 